Prepared in cooperation with the U.S. Department of Homeland Security-Federal Emergency Management Agency

\title{
Simulated and Observed 2010 Floodwater Elevations in Selected River Reaches in the Pawtuxet River Basin, Rhode Island
}

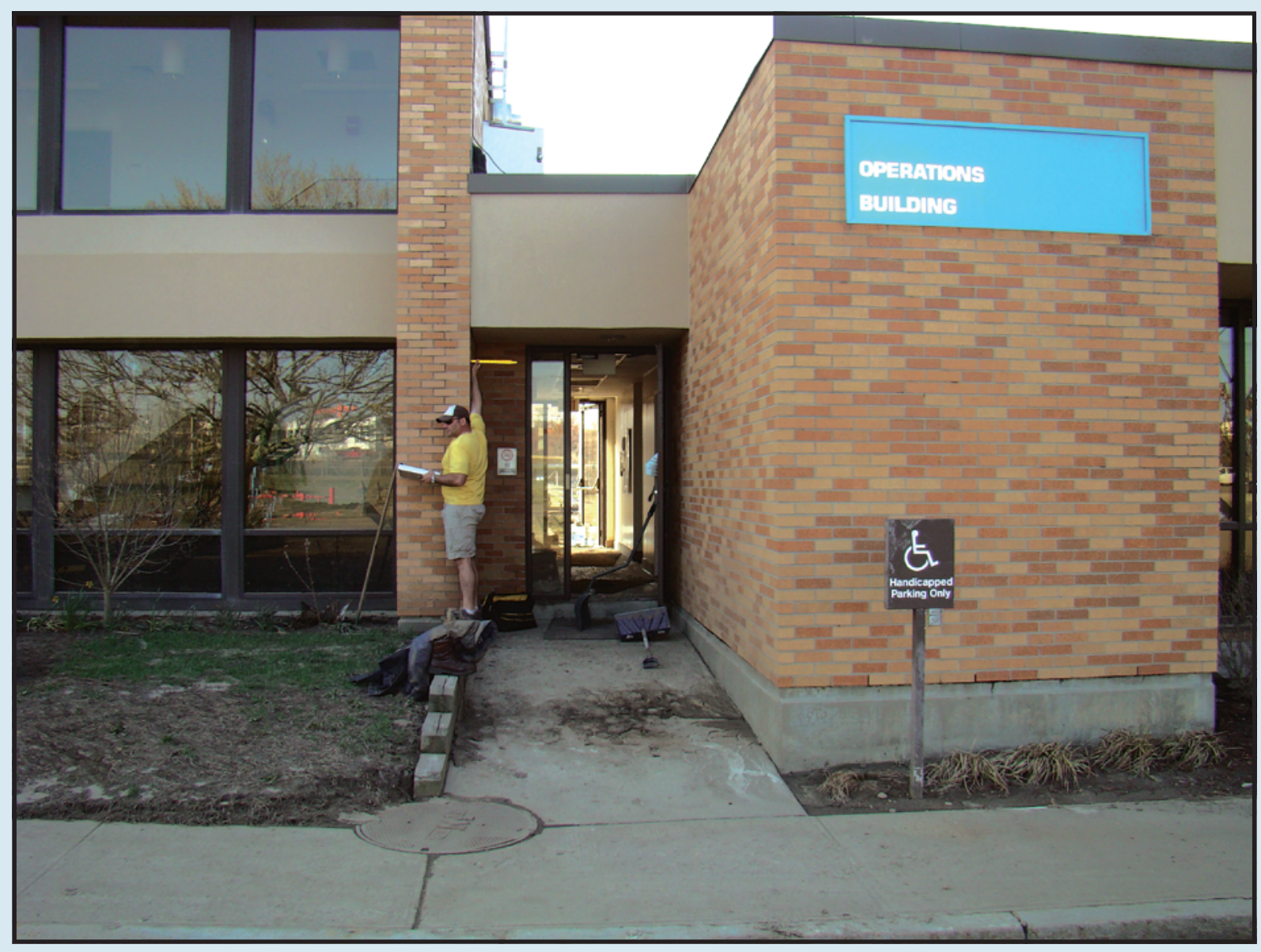

Scientific Investigations Report 2013-5192 
Front cover. Photograph showing high-water mark on the operations building at the Warwick Wastewater Treatment Facility following the March-April 2010 flood near the Pawtuxet River, Rhode Island. 


\section{Simulated and Observed 2010 Floodwater Elevations in Selected River Reaches in the Pawtuxet River Basin, Rhode Island}

By Phillip J. Zarriello, Scott A. Olson, Robert H. Flynn, Kellan R. Strauch, and

Elizabeth A. Murphy

Prepared in cooperation with the

U.S. Department of Homeland Security-Federal Emergency Management Agency

Scientific Investigations Report 2013-5192 


\title{
U.S. Department of the Interior SALLY JEWELL, Secretary
}

\section{U.S. Geological Survey Suzette M. Kimball, Acting Director}

\author{
U.S. Geological Survey, Reston, Virginia: 2014
}

For more information on the USGS - the Federal source for science about the Earth, its natural and living resources, natural hazards, and the environment, visit http://www.usgs.gov or call 1-888-ASK-USGS.

For an overview of USGS information products, including maps, imagery, and publications, visit http://www.usgs.gov/pubprod

To order this and other USGS information products, visit http://store.usgs.gov

Any use of trade, firm, or product names is for descriptive purposes only and does not imply endorsement by the U.S. Government.

Although this information product, for the most part, is in the public domain, it also may contain copyrighted materials as noted in the text. Permission to reproduce copyrighted items must be secured from the copyright owner.

Suggested citation:

Zarriello, P.J., Olson, S.A., Flynn, R.H., Strauch, K.R., and Murphy, E.A., 2014, Simulated and observed 2010 floodwater elevations in selected river reaches in the Pawtuxet River Basin, Rhode Island: U.S. Geological Survey Scientific Investigations Report 2013-5192, 49 p., http://dx.doi.org/10.3133/sir20135192. 


\section{Acknowledgments}

The authors gratefully acknowledge Kevin Farmer of the U.S. Department of Agriculture-Natural

Resources Conservation Service for sharing the updated hydraulics model of Pocasset River and its tributaries. 
THIS PAGE INTENTIONALLY LEFT BLANK 


\section{Contents}

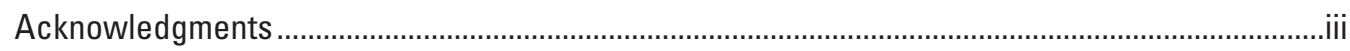

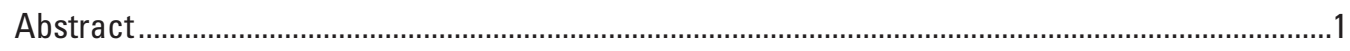

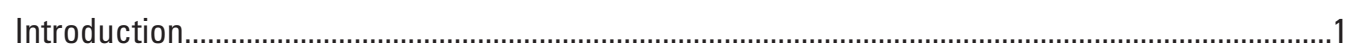

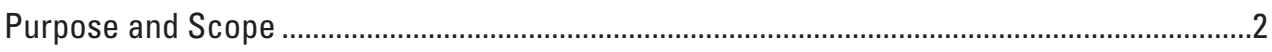

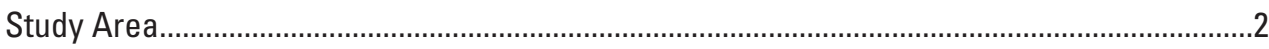

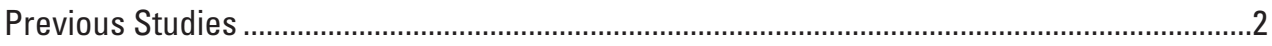

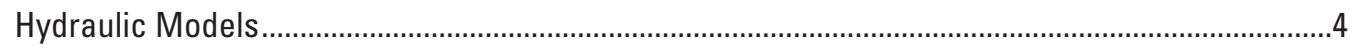

Structure and Cross-Section Updates ..............................................................................

Flood-Flow Updates........................................................................................................

Comparison of 2010 Flood High-Water Marks with Simulated Water Levels .....................................7

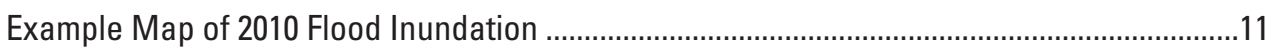

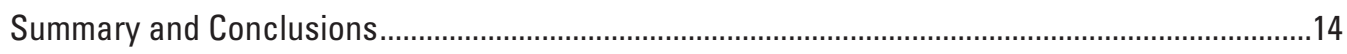

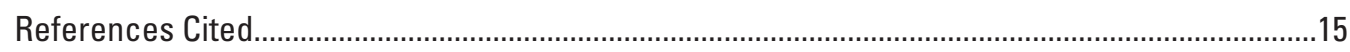

Appendix 1. Pawtuxet River Basin Hydraulic Models: Technical Data Support Notebook ..........17

Appendix 2. Review of the Hydraulic Model for the Pocasset River Basin...................................45

\section{Figures}

1. Map showing Pawtuxet River Basin and reaches with detailed hydraulic analysis, Rhode Island

2. Map showing high-water marks obtained after the 2010 flood along reaches of detailed hydraulic analysis in the Pawtuxet River Basin, Rhode Island ...........................8

3. Graphs showing differences between the 2010 flood high-water mark (HWM) elevations and water-surface elevations from the effective flood insurance study (FIS) and the updated hydraulic models for 0.2-percent annual exceedance probability flows for Rhode Island

4. Boxplot showing differences between the simulated water level at the 0.2-percent annual exceedance probability and the observed 2010 flood high-water mark (HWM) elevation in selected reaches in the Pawtuxet River Basin, Rhode Island ........10

5. Map showing flood inundation at the 0.2 -percent annual exceedance probability along the Pawtuxet River near the Warwick Wastewater Treatment Facility in Rhode Island.

6. Photograph showing high-water mark on the operations building at the Warwick Wastewater Treatment Facility following the March-April 2010 flood near the Pawtuxet River, Rhode Island. 


\section{Tables}

1. Reaches in the Pawtuxet River Basin where detailed hydraulic analyses were done....4

2. Summary of structures surveyed, the number of structures represented, and total number of cross sections in the hydraulic models of the Pawtuxet River Basin.

3. Comparison of flood insurance study and updated flood flows for selected annual exceedance probabilities in selected reaches in the Pawtuxet River Basin, Rhode Island.

4. Comparison of the effective flood insurance study (FIS) and updated hydraulic model water-surface elevations for the 0.2 -percent annual exceedance probability flows to the 2010 flood high-water mark (HWM) elevations in the Pawtuxet River Basin, Rhode Island

\section{Conversion Factors, Datum, and Abbreviations}

Inch/Pound to SI

\begin{tabular}{lcl}
\hline \multicolumn{1}{c}{ Multiply } & By & \multicolumn{1}{c}{ To obtain } \\
\hline & Length & \\
\hline foot $(\mathrm{ft})$ & 0.3048 & meter $(\mathrm{m})$ \\
mile $(\mathrm{mi})$ & 1.609 & kilometer $(\mathrm{km})$ \\
\hline & Area & \\
\hline square foot $\left(\mathrm{ft}^{2}\right)$ & 0.09290 & square meter $\left(\mathrm{m}^{2}\right)$ \\
square mile $\left(\mathrm{mi}^{2}\right)$ & 259.0 & hectare $(\mathrm{ha})$ \\
\hline & Flow rate & \\
\hline cubic foot per second $\left(\mathrm{ft}^{3} / \mathrm{s}\right)$ & 0.02832 & cubic meter per second $\left(\mathrm{m}^{3} / \mathrm{s}\right)$ \\
\hline
\end{tabular}

Vertical information is referenced to North American Vertical Datum of 1988 (NAVD 88).

Horizontal coordinate information is referenced to North American Datum of 1983 (NAD 83).

Elevation, as used in this report, refers to distance above the vertical datum. 


\section{Abbreviations}

$\begin{array}{ll}\text { AEP } & \text { annual exceedance probability } \\ \text { DFRIM } & \text { digital flood rate insurance map } \\ \text { FEMA } & \text { Federal Emergency Management Agency } \\ \text { FIS } & \text { flood insurance study; effective FIS is the latest FIS approved by FEMA } \\ \text { GIS } & \text { geographic information system } \\ \text { GPS } & \text { global positioning system } \\ \text { HEC-GeoRAS } & \text { Geographic support tool for HEC-RAS } \\ \text { HEC-RAS } & \text { Hydrologic Engineering Center-River Analysis System } \\ \text { HWM } & \text { high-water mark } \\ \text { LiDAR } & \text { light detection and ranging } \\ \text { NGTOC } & \text { National Geospatial Technical Operations Center } \\ \text { NHD } & \text { National hydrography dataset } \\ \text { NRCS } & \text { Natural Resource Conservation Service } \\ \text { TSDN } & \text { Technical Support Data Notebook } \\ \text { USACE } & \text { U.S. Army Corps of Engineers } \\ \text { USGS } & \text { U.S. Geological Survey } \\ \text { WSE } & \text { water-surface elevation }\end{array}$


THIS PAGE INTENTIONALLY LEFT BLANK 


\title{
Simulated and Observed 2010 Floodwater Elevations in Selected River Reaches in the Pawtuxet River Basin, Rhode Island
}

\author{
By Phillip J. Zarriello, Scott A. Olson, Robert H. Flynn, Kellan R. Strauch, and Elizabeth A. Murphy
}

\section{Abstract}

Heavy, persistent rains from late February through March 2010 caused severe flooding that set, or nearly set, peaks of record for streamflows and water levels at many long-term streamgages in Rhode Island. In response to this event, hydraulic models were updated for selected reaches covering about 56 river miles in the Pawtuxet River Basin to simulate water-surface elevations (WSEs) at specified flows and boundary conditions. Reaches modeled included the main stem of the Pawtuxet River, the North and South Branches of the Pawtuxet River, Pocasset River, Simmons Brook, Dry Brook, Meshanticut Brook, Furnace Hill Brook, Flat River, Quidneck Brook, and two unnamed tributaries referred to as South Branch Pawtuxet River Tributary A1 and Tributary A2. All the hydraulic models were updated to Hydrologic Engineering Center-River Analysis System (HEC-RAS) version 4.1.0 using steady-state simulations. Updates to the models included incorporation of new field-survey data at structures, high resolution land-surface elevation data, and updated flood flows from a related study.

The models were assessed using high-water marks (HWMs) obtained in a related study following the MarchApril 2010 flood and the simulated water levels at the 0.2 -percent annual exceedance probability (AEP), which is the estimated AEP of the 2010 flood in the basin. HWMs were obtained at 110 sites along the main stem of the Pawtuxet River, the North and South Branches of the Pawtuxet River, Pocasset River, Simmons Brook, Furnace Hill Brook, Flat River, and Quidneck Brook. Differences between the 2010 HWM elevations and the simulated 0.2-percent AEP WSEs from flood insurance studies (FISs) and the updated models developed in this study varied with most differences attributed to the magnitude of the 0.2-percent AEP flows. WSEs from the updated models generally are in closer agreement with the observed 2010 HWMs than with the FIS WSEs. The improved agreement of the updated simulated water elevations to observed $2010 \mathrm{HWMs}$ provides a measure of the hydraulic model performance, which indicates the updated models better represent flooding at other AEPs than the existing FIS models.

\section{Introduction}

Heavy, persistent rains from late February through March 2010 caused severe flooding that set, or nearly set, record streamflows and water levels, causing a state of emergency to be declared in many communities in Rhode Island. An Emergency Declaration was declared on March 30, 2010 (Rhode Island Severe Storms and Flooding (EM-3311), http://www.fema.gov/disasters/3311), which affected the emergency-recovery operations in all counties in Rhode Island. The flood was characterized as the worst in 200 years with damages estimated in many millions of dollars. As part of the recovery operations, the U.S. Department of Homeland Security-Federal Emergency Management Agency (FEMA) required analysis of the flood to assess damages and to prepare for and minimize future flood damages.

In a related FEMA-supported study, flood magnitudes were determined at streamgages and regional flood-flow equations were developed for ungaged sites over a range of annual exceedance probabilities (AEPs) for Rhode Island (Zarriello and others, 2012). The magnitude of flood flows for different AEPs is an important part of determining flood prone areas and risk assessment. Floods for a given magnitude are simulated in the hydraulic model of a river reach that converts flow into water levels along the reach on the basis of the river capacity or conveyance. This information then is used for delineation of flood zones, flood-plain management operations, infrastructure design, and other purposes.

The U.S. Geological Survey (USGS) entered into an agreement with FEMA in August 2010 to document and characterize the March-April 2010 flood. This study updated the hydraulic models used to simulate water-surface elevations (WSEs) over a range of AEPs in selected river reaches in the Pawtuxet River Basin. The simulated WSEs made with the updated hydraulic models, along with WSEs from the flood insurance studies (FISs), were evaluated using highwater marks (HWMs) from the March-April 2010 flood in the Pawtuxet River Basin. The updated models and the evaluation of the March-April 2010 flood are important for post-flood analysis and provide tools for future flood-management needs. 


\section{Purpose and Scope}

The purpose of this report is to document the development of Hydrologic Engineering Center-River Analysis System (HEC-RAS) hydraulic models (Brunner, 2010a, b) that were used to simulate WSEs over a range of AEPs flood flows in the Pawtuxet River Basin. The WSEs computed with the updated models are compared to WSEs reported in the effective FIS (the latest FIS approved by FEMA) and to the MarchApril 2010 HWMs, which is estimated to be about equal to a 0.2-percent AEP flood in the Pawtuxet River Basin.

Hydraulic models were developed for the Pawtuxet River, North Branch Pawtuxet River, South Branch Pawtuxet River and nine tributary reaches - the Pocasset River, Simmons Brook, Dry Brook, Meshanticut Brook, Furnace Hill Brook, Flat River, Quidneck Brook, and South Branch Pawtuxet River Tributaries A1 and A2. Appendix 1 provides information similar to the FEMA Technical Support Data Notebook (TSDN) guidelines (2011) for documenting hydraulic models for FISs for all reaches except those in the Pocasset River Basin. The Pocasset River Basin model, which includes Simmons and Dry Brooks, was developed by the Natural Resources Conservation Service (NRCS); however, flows were modified for given AEPs using the regional-flood equations for Rhode Island (Zarriello and others, 2012). A review of the Pocasset River Basin model is provided in appendix 2 .

\section{Study Area}

The Pawtuxet River Basin covers an area of about 232 square miles $\left(\mathrm{mi}^{2}\right)$ in central Rhode Island that discharges into Pawtuxet Cove at the northern end of Narragansett Bay just south of the City of Providence (fig. 1). Hydraulic models were developed for the main stem of the Pawtuxet River, North Branch Pawtuxet River, South Branch Pawtuxet River, and nine tributaries. The Pawtuxet River is a sinuous low-gradient river that runs about 11.2 miles (mi) northeast through heavily urbanized areas from the confluence of the North and South Branches to the mouth. The North Branch Pawtuxet River has a drainage area of about $110 \mathrm{mi}^{2}$ and runs about 6.6 mi southeast from the outlet of Scituate Reservoir to its confluence with the South Branch. The South Branch Pawtuxet River has a drainage area of about $73 \mathrm{mi}^{2}$ and runs east and then north about $9.1 \mathrm{mi}$ from the outlet of Flat River Reservoir to its confluence with the North Branch.

Tributaries to the main stem of the Pawtuxet River that were modeled (values in parentheses are the length of reach modeled) include the Pocasset River (11.8 mi) and two of its tributaries-Simmons Brook (3.6 mi) and Dry Brook (3.0 mi) - and Meshanticut Brook (4.6 mi) and one of its tributaries-Furnace Hill Brook (2.6 mi). These tributaries generally run through heavily urbanized areas. The other tributaries modeled flow into the South Branch Pawtuxet River and include Flat River (2.8 mi), Quidneck Brook (0.67 mi), and two unnamed tributaries referred to as South Branch Pawtuxet River Tributary A1 (0.52 mi) and South Branch Pawtuxet River Tributary A2 (0.04 mi). Tributaries to the South Branch Pawtuxet River generally run through rural areas.

The Pawtuxet River Basin is in three countiesProvidence, Kent, and a small part of Washington County. The basin covers nine towns including all or most of Scituate and West Warwick; large parts of Coventry, West Greenwich, Johnston, and Foster; and small parts of East Greenwich, Exeter, and Glocester. The lower southeastern part of the basin is within parts of the cities of Cranston, Providence, and Warwick. The lower part of the Pawtuxet River is bordered to the north by the City of Cranston and to the south by the City of Warwick.

\section{Previous Studies}

Pawtuxet River Basin hydrology and hydraulic analyses are described in the FISs for Kent County (FEMA, 2010; no. 44003CV001A) and Providence County (FEMA, 2009; no. 44007CV001A). These countywide FISs revise and supersede all previous community FIS reports that were first developed by town or city in the 1970s in response to the National Flood Insurance Act of 1968 and the Flood Disaster Protection Act of 1973. Community reports, which were limited in extent to community boundaries, are summarized in the countywide reports. The hydrology and hydraulic analyses reflect a variety of analytical techniques and hydraulic models depending on who did the study and when it was done. Previous FIS-specific flows generally were consistent across community boundaries, but different values were sometimes reported. Although the community FISs were revised over time, the recent countywide FISs hydrologic analyses generally are the same as those reported in the earliest community FISs.

Flood flows reported in the 2009 Providence and 2010 Kent County FIS reports generally can be traced back to peak-flow streamgage record analysis of the Pawtuxet River at Cranston (01116500) or the South Branch Pawtuxet River at Washington (01116000) for flows in these reaches. The analysis was limited to the period of record at these streamgages at the time the analysis was done, which varied by community study but appears to include no more than about 30 years of record. In the main stem of the Pawtuxet River, most flood flows were determined from an earlier analysis by the U.S. Army Corps of Engineers (USACE) using the Beard's plotting position of annual peak discharges from Pawtuxet River at Cranston (01116500) for 26 years of record (1940-66) (FEMA, 2009). The USACE analysis included a peak from 1886 that was reported to be about equal in magnitude to the observed peak of record in 2010; however, no supporting information is given about how this flow was determined. Flood flows for other reaches in the Pawtuxet River Basin generally were determined by simulations made with the rainfall-runoff model TR-20 (U.S. Department of Agriculture, 1965) or by regional flood-flow equations for 


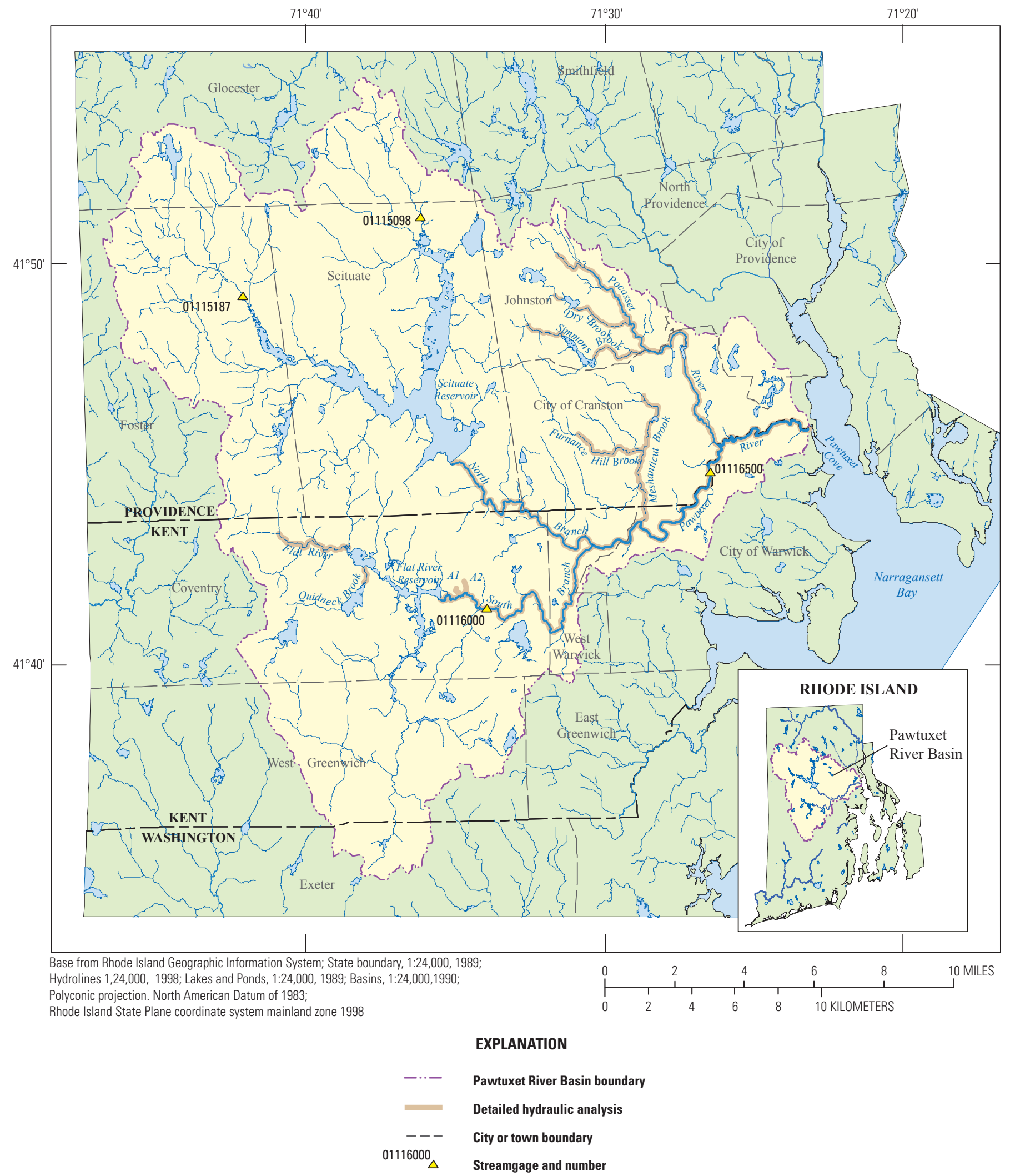

Figure 1. Pawtuxet River Basin and reaches with detailed hydraulic analysis, Rhode Island. 
Rhode Island for small basins by Johnson and Laraway (1976). The TR-20 computed flood flows were simulated from the NRCS, formerly the Soil Conservation Service (SCS), Type-III distribution of the 48-hour total precipitation for different AEPs, which was assumed to produce an equivalent AEP flood flow. For example, a 100-year (1-percent AEP) 48-hour rainfall was assumed equal to a 1-percent AEP flood flow. Total precipitation for a given exceedance probability was obtained from National Weather Service Atlas Technical Publication 40 (TP-40) (U.S. Department of Commerce, 1961). It should be noted that a Type-II distribution was sometimes reported, but this was assumed to be a typographic error as the Type-III distribution applies to this area.

Flood flows were determined from at-site analysis of the streamgage annual peak-flow records through 2010 and regional-regression equations for estimating flood flows at ungaged sites by Zarriello and others (2012). Estimates of uncertainty of the at-site and regression flood magnitudes are provided and were combined with their respective estimated flood quantiles to improve estimates of flood flows at streamgages.

The hydraulic model for the Pocasset River and its tributaries-Dry Brook and Simmons Brook-was updated in 2006 by the NRCS using HEC-RAS (Bachand and others, 2007; Schmidt and others, 2007). The NRCS model flows were determined by TR-20 methods using extreme precipitation in New England (DeGaetano and Zarrow, undated) to update the rainfall-frequency totals in TP-40. The Pocasset River Basin model developed by the NRCS was modified in this study with updated regional flows using methods from Zarriello and others (2012).
Following the record flooding during March-April 2010, 110 HWMs were obtained by the USGS and the USACE along the modeled reaches in the Pawtuxet River Basin. The HWM elevations were surveyed to North American Vertical Datum of 1988 (NAVD 88) and documented by Zarriello and Bent (2011). These flood elevations were used to compare to simulated flood elevations for similar exceedance probability floods reported in FISs and developed in this study with updated models.

\section{Hydraulic Models}

Existing hydraulic models for selected reaches in the Pawtuxet River Basin were updated to HEC-RAS version 4.1.0 (Brunner, 2010a, b), a one-dimensional hydraulic model. Steady-state flow conditions were simulated for specified flows, boundary conditions, and the river's flow carrying capacity or conveyance. The flows input to the model were for select AEP floods using information and methods developed by Zarriello and others (2012). All WSEs reported in this study are in feet and are referenced to the NAVD 88. Revisions of hydraulic models were made to priority reaches identified by the Rhode Island Emergency Management Agency in consultation with FEMA; the priority reaches identified in the Pawtuxet River Basin cover about 56 river miles (table 1, fig. 1).

Input data from existing hydraulic models were obtained from archived (microfiche) files of HEC-2 or WSP-2 models developed for community FISs and converted to the input format for HEC-RAS. HEC-2 (U.S. Army Corps of Engineers,

Table 1. Reaches in the Pawtuxet River Basin where detailed hydraulic analyses were done.

[The indentations in column 1 indicate tributaries in decreasing stream order]

\begin{tabular}{ccll}
\hline Modeled reaches & $\begin{array}{c}\text { Reach length } \\
\text { (miles) }\end{array}$ & \multicolumn{1}{c}{ City or town } & County \\
\hline Pawtuxet River (main stem) & 11.2 & Cranston, Warwick, West Warwick & Providence, Kent \\
Pocasset River & 11.7 & Cranston, Johnston & Providence \\
Dry Brook & 3.0 & Johnston & Providence \\
Simmons Brook & 3.6 & Johnston & Providence \\
Meshanticut Brook & 4.6 & Cranston, Warwick & Providence \\
Furnace Hill Brook & 2.6 & Cranston & Providence \\
North Branch Pawtuxet River & 6.6 & Coventry, Cranston, Scituate, West Warwick & Providence, Kent \\
South Branch Pawtuxet River & 9.1 & Coventry, West Warwick & Providence, Kent \\
Tributary A1 & .52 & Coventry & Kent \\
Tributary A2 & .04 & Coventry & Kent \\
Quidneck Brook & .67 & Coventry & Kent \\
Flat River & 2.8 & Coventry & Kent \\
\hline
\end{tabular}


1991) and WSP-2 (Water Surface Profile program) developed by the U.S. Department of Agriculture (1976) are step backwater hydraulic models, which were in use at the time of the earlier FISs. The NRCS provided a HEC-RAS model recently developed (2006) for the Pocasset River Basin (Kevin Farmer, NRCS, written commun., 2011). The NRCS HEC-RAS model was reviewed but the only changes made to the model were the flows specified for different AEP floods.

\section{Structure and Cross-Section Updates}

Early in the study, it became apparent that the existing hydraulic models did not always reflect current (2011) conditions and updated information at structures such as bridges, culverts, and dams, and their approaches and exits, was needed to better reflect the conveyance capacity of the reach. As part of this study, field surveys of channel and structure geometry were obtained along the modeled reaches at most riverine structures according to FEMA standards for flood-hazard mapping (FEMA, 2011). Field surveys included 27 dams, 49 bridges, and 28 culverts (table 2). As part of the riverine structural surveys, channel and bank profiles and the approach to and exit from the structures typically were surveyed. The new survey information also provided accurate georeferencing of the structures in the updated hydraulic models. Structures in the Pocasset River Basin were not surveyed as part of this study but are reported to have been updated during the NRCS model update (Bachand and others, 2007; Schmidt and others, 2007).

The American Recovery and Reinvestment Act of 2009 provided stimulus funding to a consortium of partners for light detection and ranging (LiDAR) mapping for the northeastern coastal U.S. including all of Rhode Island (accessed December 14, 2012, at http://www.neurisa.org/NE_LiDAR_Project). This work was coordinated and contracted through the USGS National Geospatial Technical Operation Center (NGTOC), whose contract specifications meet or exceed FEMA standards for hydraulic analysis (Heidemann, 2012). The NGTOC also provides quality assurance and control of LiDAR acquisition and interpretation. The LiDAR data provide accurate vertical ground-surface elevation (within $\pm 0.5 \mathrm{ft}$ ) for every pixel nominally spaced every 2 meters $(6.24 \mathrm{ft})$ of land surface in Rhode Island. LiDAR data were not expected to be available for this study, but the data for Rhode Island became available in November 2011 when most of the hydraulic model work was in progress. Accordingly, the USGS, in consultation with the FEMA, agreed to expand the scope of this study to utilize the LiDAR data. Cross sections developed from the LiDAR data are georeferenced in the hydraulic models and provide consistency with the land-surface elevation data that are needed to develop accurate flood inundation maps. The LiDAR data also allow additional cross sections to be added

Table 2. Summary of structures surveyed, the number of structures represented, and total number of cross sections in the hydraulic models of the Pawtuxet River Basin.

[--, Pocasset River model and its tributaries were revised by the Natural Resources Conservation Service, information on structures surveyed was not available; total sections, total number of cross sections in the model]

\begin{tabular}{|c|c|c|c|c|c|c|c|}
\hline \multirow{2}{*}{ Reach } & \multicolumn{2}{|c|}{ Dams } & \multicolumn{2}{|c|}{ Bridges } & \multicolumn{2}{|c|}{ Culverts } & \multirow{2}{*}{ Total sections } \\
\hline & Surveyed & Modeled & Surveyed & Modeled & Surveyed & Modeled & \\
\hline Pawtuxet River main stem & 3 & 4 & 15 & 17 & 0 & 0 & 205 \\
\hline Pocasset River & -- & 4 & -- & 10 & -- & 15 & 493 \\
\hline Pocasset River split & -- & 0 & -- & 0 & -- & 1 & 35 \\
\hline Dry Brook & -- & 2 & -- & 1 & -- & 4 & 93 \\
\hline Simmons Brook & -- & 2 & -- & 2 & -- & 5 & 128 \\
\hline Meshanticut Brook & 1 & 2 & 3 & 3 & 17 & 18 & 149 \\
\hline Furnace Hill Brook & 1 & 1 & 6 & 6 & 5 & 5 & 91 \\
\hline North Branch Pawtuxet River & 17 & 6 & 29 & 7 & 0 & 0 & 87 \\
\hline South Branch Pawtuxet River & 11 & 11 & 11 & 11 & 0 & 0 & 188 \\
\hline Tributary A1 & 0 & 0 & 0 & 0 & 2 & 4 & 24 \\
\hline Tributary A2 & 0 & 0 & 0 & 0 & 1 & 1 & 5 \\
\hline Quidneck Brook & 2 & 2 & 2 & 3 & 1 & 2 & 50 \\
\hline Flat River & 2 & 3 & 5 & 5 & 2 & 6 & 100 \\
\hline Total & 27 & 37 & 42 & 65 & 28 & 61 & 1,648 \\
\hline
\end{tabular}

${ }^{1}$ Includes the remnants of a former dam.

${ }^{2}$ Two railroad bridge abutments were surveyed but the bridges themselves were not included in the model because of the deck height above the river. 
where distances between the existing cross sections exceed the recommended standards. The cross sections also could be extended to fully incorporate the areas inundated that were truncated by the limits of the previous cross-section line. The limitation of the LiDAR data is the channel geometry below the water surface had to be interpolated from previous channel cross-section information except near where it was determined by the field surveys made during this study. Future revisions to the hydraulic models should consider updating the in-channel cross-section information.

In anticipation that the updated hydraulic models may be used later as part of the FEMAs revisions to the National Flood Insurance Program (NFIP) flood maps, the models have been documented in a manner similar to FEMA's TSDN format (FEMA, 2011). The TSDN is included in appendix 1 for all the hydraulic models in this study except for the Pocasset River Basin reaches, which were developed by the NRCS. A review of the Pocasset River Basin model is provided in appendix 2 . The hydraulic models developed for this study were not submitted to the FEMA under the Map Information Product (MIP) system at this time because flood insurance maps were not part of this study.

\section{Flood-Flow Updates}

The flood flows input to the HEC-RAS models used in this study were updated from information in the "Magnitude of Flood Flows for Selected Annual-Exceedance Probabilities in Rhode Island, through 2010" by Zarriello and others (2012). The flood-frequency report was developed as part of the same FEMA supported work as this study in response to the 2010 flood. The report updates estimates of flood magnitudes at streamgages and provides regional equations for computing flood magnitude at ungaged sites for 20-, 10-, 4-, 2-, 1-, 0.5-, and 0.2-percent AEPs. Methods also were presented to calculate AEP flood flows at an ungaged site on a gaged stream, which were used to estimate flows in the lower Pawtuxet River reach and the South Branch Pawtuxet River reach.

North Branch Pawtuxet River, which is ungaged and affected by upstream storage in the Scituate Reservoir, was not calculated by the methods presented by Zarriello and others (2012) because the regional flood-flow equations are not applicable for regulated streams. To estimate the AEP flood flows for this river reach, the log-Pearson Type-III method described in Bulletin 17B (U.S. Interagency Advisory Committee on Water Data, 1982) were applied to estimated annual peaks in the North Branch Pawtuxet River. Annual peak flows were determined from the difference in annual peak flows measured at the Pawtuxet River at Cranston (01116500) and the South Branch Pawtuxet River at Washington (01116000), and adjusted for drainage area. Details of how the AEP flows were estimated for the North Branch Pawtuxet River are provided in appendix 1 .

The flood flows used in the latest FISs for Providence (FEMA, 2009) and Kent (FEMA, 2010) counties are generally the same as the flood flows used in the original community FISs, which were determined from methods and information that typically dates back to the 1970 s or earlier. The 10-, 2-, 1-, and 0.2-percent AEP flood flows in the effective FIS reports and those computed in this study are summarized in table 3 . Flood flows from past FIS reports and flows used by the NRCS in the 2006 update to the hydraulic model of the Pocasset River Basin also are reported.

Table 3. Comparison of flood insurance study and updated flood flows for selected annual exceedance probabilities in selected reaches in the Pawtuxet River Basin, Rhode Island.

[Available separately at http://pubs.usgs.gov/sir/2013/5192/ tables/sir2013-5192_tables03-04.xls]

In general, the updated flood flows used in this study were substantially less (about 40 to 80 percent) than the flood flows computed by the TR-20 rainfall-runoff model for a comparable AEP 48-hour rainfall. The total rainfall was distributed using the SCS Type-III distribution (U.S. Department of Agriculture, 1965); however, it should be noted that not all FIS reports explicitly state the design storm or the distribution type used (namely, Pocasset River, Simmons Brook, Dry Brook, Meshanticut Brook, and Furnace Hill Brook). In the Pocasset River Basin HEC-RAS model recently (2006) developed by the NRCS, flood flows were estimated using TR-20 and an updated rainfall frequency developed by the Northeast Regional Climate Center (DeGaetano and Zarrow, undated). The resulting AEP floodflow values generally were less than the effective FIS flood flows but still appreciably larger than the comparable AEP flows determined from the regional-regression equations by Zarriello and other (2012) used in this study.

Flood flow determined from streamgage records at South Branch Pawtuxet River (01116000) and the main stem Pawtuxet River (01116500) were 4 to 57 percent greater for 10-, 2-, and 1-percent AEP flows in this study relative to the equivalent AEP flows in the FIS. However, the updated 0.2-percent AEP flows generally were appreciably less (up to about 30 percent) than the values used in the effective FIS. The updated AEP flows for the North Branch Pawtuxet River were 24 to 37 percent greater than the flows used in the effective FIS.

The AEP flows used in the effective FIS for tributaries to the South Branch Pawtuxet River were computed from equations developed by Weiss (1975) for urbanized and nonurbanized areas in Connecticut. The comparable AEP flood flows used in this study were about 60 to 72 percent less than the effective FIS flows in Quidneck Brook and about 14 to 50 percent less than the effective FIS flows in Flat River. The method used to determine the effective FIS flows for the South Branch Pawtuxet River Tributaries A1 and A2 are uncertain. In places flow in Tributaries A1 and A2 was reported to be computed using equations by Weiss (1975), but the 2010 FIS for Kent County (FEMA, 2010) indicates the HEC-1 rainfallrunoff model was used to estimate flows in these tributaries. 


\section{Comparison of 2010 Flood High-Water Marks with Simulated Water Levels}

One of the objectives of this study was to compare the 2010 flood HWM elevations to those simulated for a similar AEP flood to assess the effective FIS and updated hydraulic models simulated WSEs. The HWMs were obtained at 110 sites along the model reaches in the Pawtuxet River Basin (Zarriello and Bent, 2011); most of these HWMs were obtained along the main stem of the Pawtuxet River, North Branch Pawtuxet River, and South Branch Pawtuxet River (fig. 2). A few HWMS were obtained along the Pocasset River, Flat River, Simmons Brook, Furnace Hill Brook, and Quidneck Brook.

The 2010 flood was estimated to have about a 0.2 -percent AEP on the basis of flood-frequency analysis of streamgage annual-peak flows at Pawtuxet River at Cranston, R.I. (0116500), South Branch at Pawtuxet River at Washington, R.I. (0116000), and Nooseneck River at Nooseneck, R.I. (01115630) (Zarriello and others, 2012; table 17). Although the observed 2010 peak flows at the streamgages do not match exactly the 0.2-percent AEP flows, the simulated WSE at the 0.2-percent AEP flow in the effective FIS and the updated models provide a common basis from which WSEs for similar AEP floods can be compared. In some reaches, the 2010 peak flows were simulated to directly compare differences in the WSE and the HWMs, which was used to modify the hydraulic representation of the reach in the model. However, this can be done only where the peak-flow data are available or could be reasonably estimated from the streamgage records.

It should be noted that the model-simulated WSEs are determined on the basis of unobstructed flow from debris and the simulated WSE is considered valid only if structures and the stream channel remain clear of temporary obstructions. During field reconnaissance and field surveys, and reviewing photographs obtained from the WEB, it was determined that this condition does not always appear to be true; a lower simulated WSE would be expected compared to the observed 2010 HWM elevations when obstructions are present. It also should be noted that the quality of HWMs vary and are subject to uncertainty.

In general, the updated model-simulated WSEs are in closer agreement with the observed 2010 flood HWMs than the effective FIS WSEs at the 0.2-percent AEP flows (table 4). If the flow in the effective FIS was determined from TP-20, the simulated WSE were appreciably larger than the observed 2010 HWM elevations because the TR-20 derived flows were appreciably larger than the updated flows. However, if the effective FIS flow was determined from the streamgage records, the simulated WSE was in better agreement with the observed 2010 HWM elevations, but did not agree as well as the updated-model WSEs. The differences between the observed 2010 HWM elevations, and the simulated WSEs from the effective FIS and the updated models varied along a given reach (fig. 3). Boxplots indicate that the overall differences between the 2010 HWM elevations and the WSEs from the effective FIS are much greater than those for WSEs from the updated models (fig. 4).

Table 4. Comparison of the effective flood insurance study (FIS) and updated hydraulic model water-surface elevations for the 0.2-percent annual exceedance probability flows to the 2010 flood high-water mark (HWM) elevations in the Pawtuxet River Basin, Rhode Island.

[Available separately at http://pubs.usgs.gov/sir/2013/5192/ tables/sir2013-5192_tables03-04.xls]

The main-stem Pawtuxet River simulated flow at the 0.2-percent AEP in the updated model at the Cranston (01116500) streamgage was about equal (less than 1 percent difference) to the recorded 2010 peak flow-15,000 and 14,900 cubic feet per second $\left(\mathrm{ft}^{3} / \mathrm{s}\right)$, respectively. However, the effective FIS flow at the 0.2-percent AEP was about 32 percent greater $\left(19,600 \mathrm{ft}^{3} / \mathrm{s}\right)$ than the recorded 2010 peak flow at the streamgage. Correspondingly, the WSEs at the 0.2-percent AEP in the effective FIS were consistently higher (up to 26 percent) than the WSEs in the updated model (fig. 3A). The updated model WSEs were about the same or slightly less than the 2010 HWM elevations along most of the reach (fig. 3A). On average, differences in the simulated WSEs at the 0.2-percent AEP in comparison with the 2010 HWM elevations were about 0.1 foot (ft) lower in the updated model and about $5.0 \mathrm{ft}$ higher in the effective FIS. Boxplots indicate that in comparison to the 2010 HWM elevations, the updated WSEs were about equally distributed around zero (no difference), but the effective FIS WSEs were consistently well above the 2010 HWM elevations (fig. 4). As previously noted, places where the updated model undersimulated the 2010 HWM elevations are likely caused by obstructions in the channel.

The North Branch Pawtuxet River simulated flow at the 0.2-percent AEP in the updated model was 27 percent less in the lower reach and 37 percent greater in the upper reach relative to the effective FIS flows; the effective FIS flows were from two separate models that originated from different community FIS studies. The differences between the effective FIS WSEs and the observed 2010 flood HWM elevations (fig. 3B) were inconsistent in the lower reach (below a distance of $10,000 \mathrm{ft}$ ), but were higher in the upper reach (above a distance of 18,000 ft) reflecting the relatively higher discharge simulated in the upper reach. At the 0.2-percent AEP flow, the effective FIS WSEs averaged about $1.0 \mathrm{ft}$ above the 2010 HWM elevations; boxplots (fig. 4) indicate most FIS WSEs were above the zero line. At the 0.2-percent AEP flow, the updated model WSEs averaged $0.02 \mathrm{ft}$ less than the 2010 HWM elevations and generally were in closer agreement than the effective FIS WSEs (fig. 3B). Differences in the updated model WSEs and the HWMs were about equally distributed around the zero line (fig. 4). 


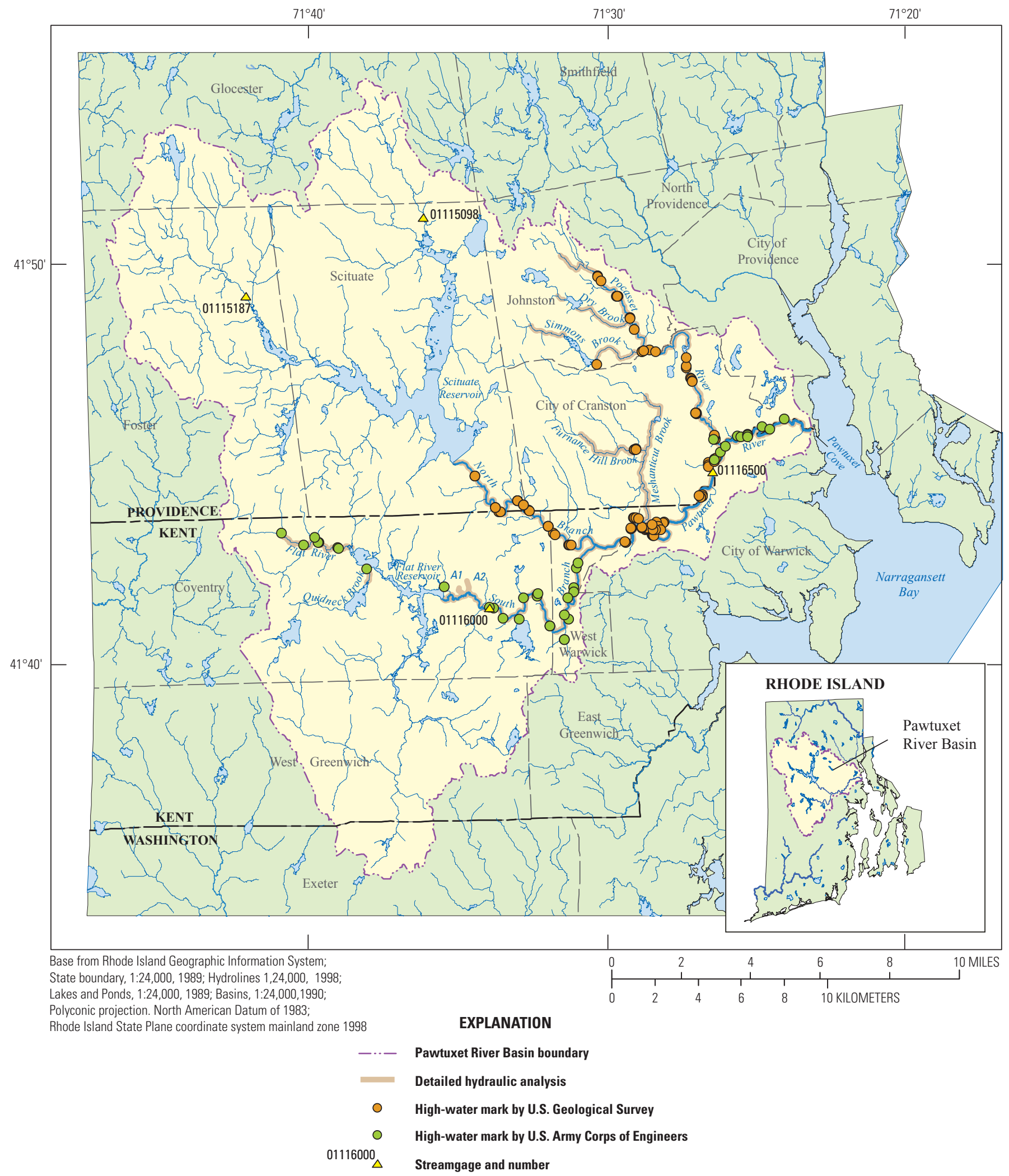

Figure 2. High-water marks obtained after the 2010 flood along reaches of detailed hydraulic analysis in the Pawtuxet River Basin, Rhode Island. 
A. Pawtuxet River

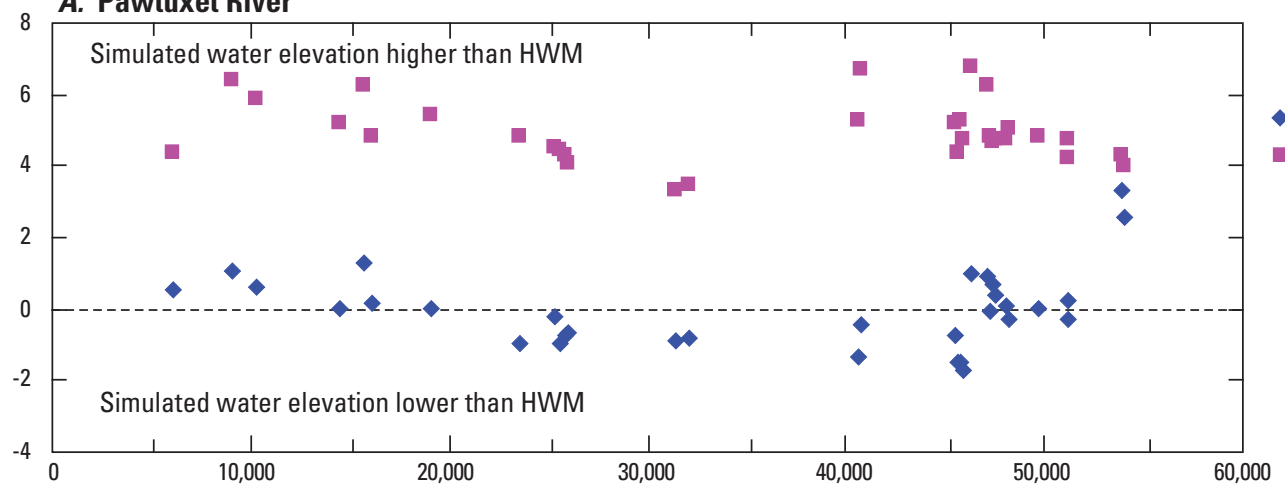

EXPLANATION

Pawtuxet River

- Updated model

- Effective FIS

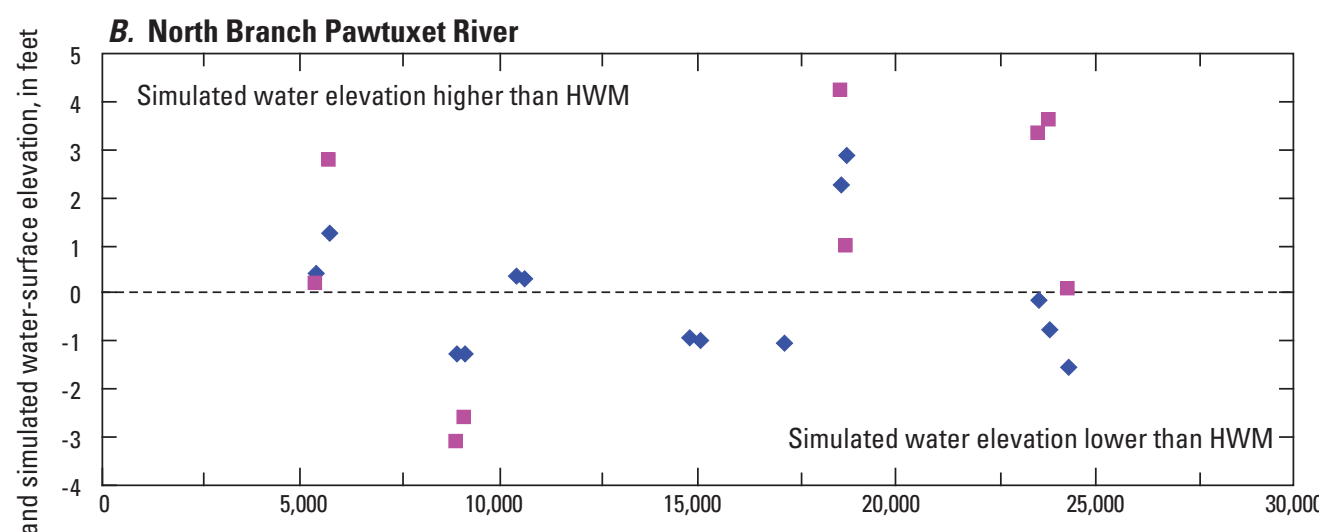

EXPLANATION

North Branch

Pawtuxet River

- Updated model

- Effective FIS

C. South Branch Pawtuxet River Subbasin

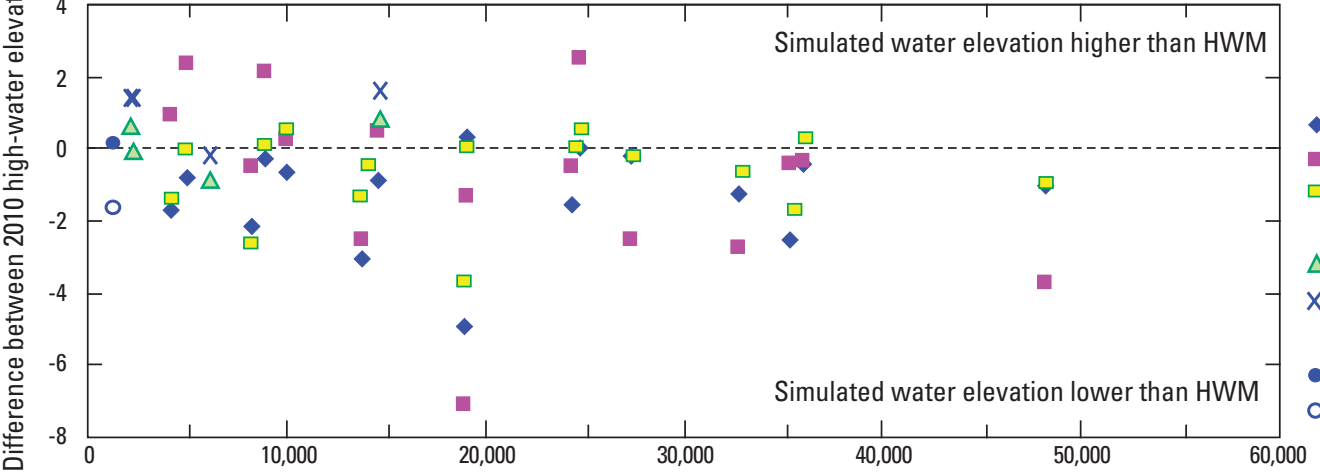

EXPLANATION

South Branch

Pawtuxet River

- Updated model

- Effective FIS

2010 peak fow

Flat River

$\triangle$ Updated model

$X$ Effective FIS

Quidneck Brook

- Effective FIS

Updated model

D. Pocasset River Subbasin

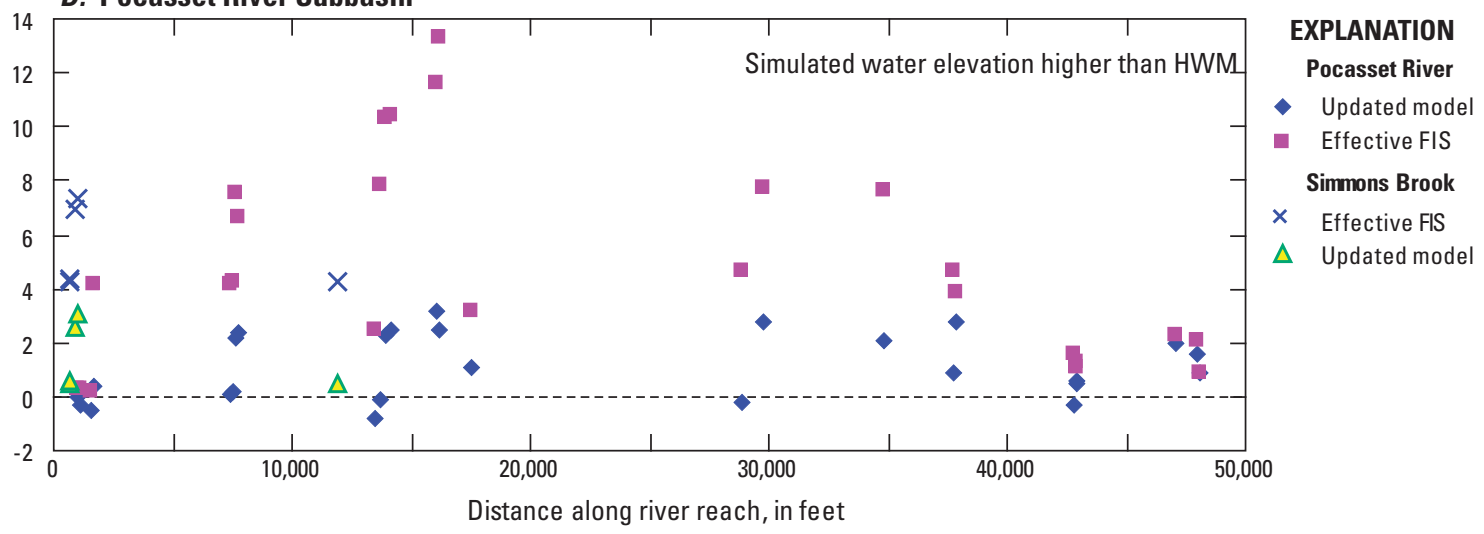

Figure 3. Differences between the 2010 flood high-water mark (HWM) elevations and water-surface elevations from the effective flood insurance study (FIS) and the updated hydraulic models for 0.2-percent annual exceedance probability flows for Rhode Island. A, Pawtuxet River. B, North Branch Pawtuxet River. C, South Branch Pawtuxet River Subbasin. $D$, Pocasset River Subbasin. 


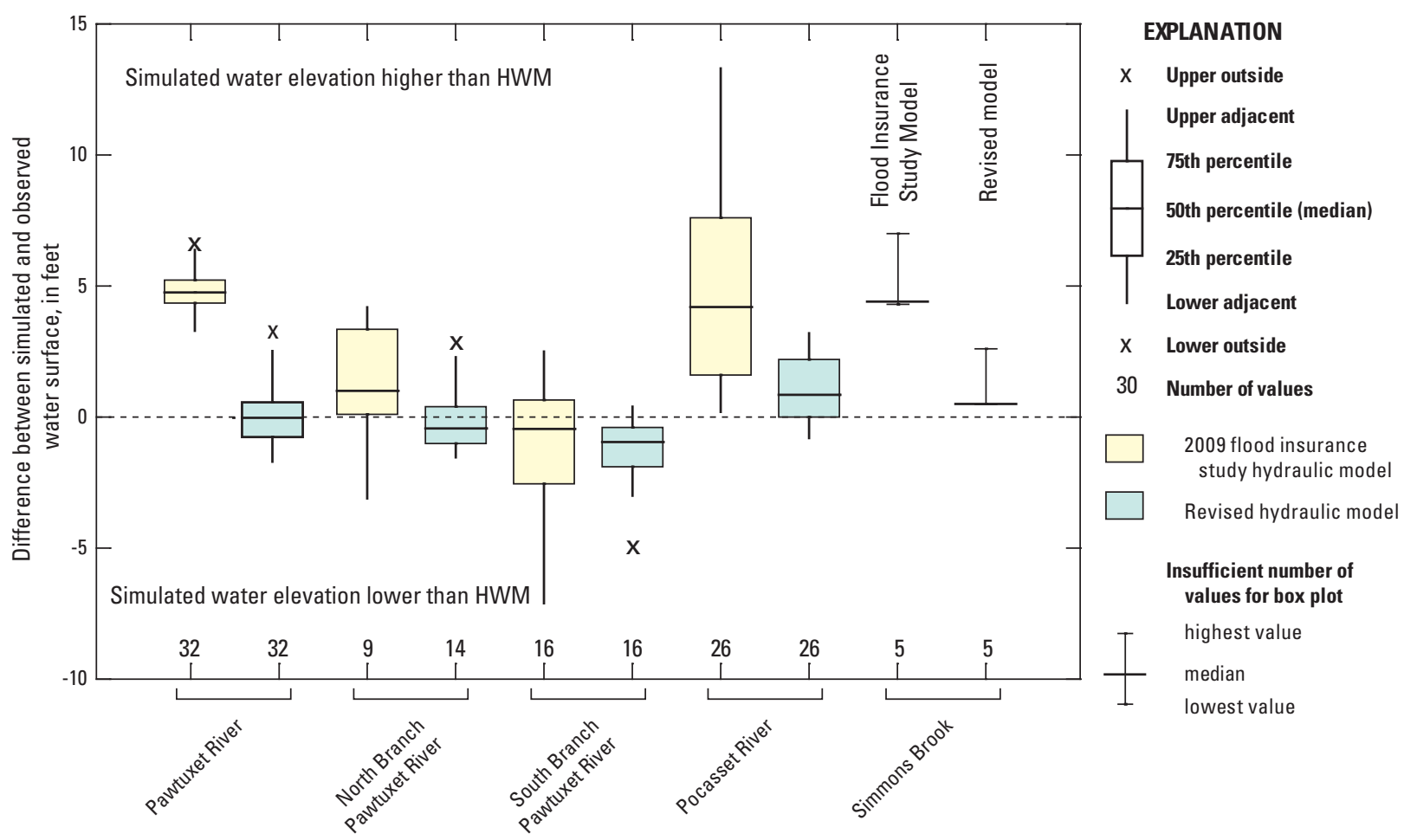

Figure 4. Differences between the simulated water level at the 0.2-percent annual exceedance probability and the observed 2010 flood high-water mark (HWM) elevation in selected reaches in the Pawtuxet River Basin, Rhode Island.

The South Branch Pawtuxet River streamgage at the Washington (01116000) 2010 peak flow $\left(5,480 \mathrm{ft}^{3} / \mathrm{s}\right)$ was about 17 percent greater than the 0.2 -percent AEP flow in the updated model $\left(4,680 \mathrm{ft}^{3} / \mathrm{s}\right)$ and 20 percent greater than the 0.2 -percent AEP flow in the effective FIS model $\left(4,580 \mathrm{ft}^{3} / \mathrm{s}\right)$. Correspondingly, both the effective FIS and the updated model WSEs at the 0.2-percent AEP flow generally undersimulate the 2010 HWM elevations in the South Branch Pawtuxet River (figs. 3C and 4). On average, the WSEs in effective FIS and updated models were about 0.8 and $1.3 \mathrm{ft}$ less, respectively, than the 2010 HWM elevations; however, the range of differences (fig. 4) between the simulated and observed WSEs was less in the updated model ( -4.2 to $0.3 \mathrm{ft})$ than the effective FIS ( -7.1 to $2.3 \mathrm{ft}$ ). When the 2010 peak flow was simulated in the updated model (with adjustments for drainage area), the differences between the simulated and observed WSEs were less than 1 percent. Locations where the model WSE is less than the observed 2010 HWM indicate debris or increased roughness from debris that caused the actual water level to be higher than the simulated water level.
HWMs in tributaries to the South Branch Pawtuxet River from the 2010 flood were limited to four sites in Flat River and one site in Quidneck Brook. Differences between the simulated WSEs at the 0.2-percent AEP flow and the 2010 HWMs in the Flat River generally were less for the updated model than for the effective FIS (fig. 3C). On average, the Flat River effective FIS WSE was $1.1 \mathrm{ft}$ higher than the 2010 HWM elevations, and the updated model WSE was $0.1 \mathrm{ft}$ higher than the 2010 HWM elevation. In Quidneck Brook, the simulated WSE at the 0.2-percent AEP flow was $0.2 \mathrm{ft}$ higher in the effective FIS and $1.6 \mathrm{ft}$ lower in the updated model than the 2010 HWM elevation. These differences largely reflect the differences in the 0.2-percent AEP flow simulated in the effective FIS and updated models; updated flows in Flat River and Quidneck Brook models averaged 30 and 64 percent less than the effective FIS flows, respectively.

The Pocasset River 0.2-percent AEP flows in the updated model averaged about 63 percent less than the flows in the 2006 NRCS model with differences generally increasing from upstream to downstream. Correspondingly, the updated 
model WSE was lower than the NRCS model WSE (fig. 3D). In comparison to the 2010 HWM elevation, the NRCS model WSEs ranged from about 0.3 to $13 \mathrm{ft}$ higher, and the updated model WSEs ranged from about -0.8 to $3.2 \mathrm{ft}$ different (table 4; fig. 4). On average, the NRCS model WSEs were about $4.8 \mathrm{ft}$ higher than the 2010 HWM elevations and the updated model WSEs were about $1.1 \mathrm{ft}$ higher than the 2010 HWM elevations. These differences are based on setting the starting WSE equal to the WSE of the Pawtuxet River at the confluence of the Pocasset River.

In Simmons Brook, a tributary to the Pocasset River, only five HWMs were obtained following the 2010 flood. At the 0.2-percent AEP flow, the NRCS and updated model WSEs also were above the observed 2010 HWM elevations (fig. 4), averaging about 5.4 and $1.4 \mathrm{ft}$ above the 2010 HWM elevations, respectively. The oversimulated WSE elevations may be caused by an overestimation of the AEP of the 2010 peak in the Pocasset River and Simmons Brook. The WSEs were computed from 0.2-percent AEP flows, but the 2010 peak in the Woonasquatucket River just to the north was estimated to have a 2-percent AEP.

The previous comparisons were made on the basis of the 0.2-percent AEP flow. Estimated flows for a given AEP can vary appreciably within the 95 -percent confidence interval as determined from streamgage-record analysis or regionalized flood-flow equations, or both. The upper confidence interval is often 2 to 3 times the best estimated value for a given AEP. The uncertainty of the flood magnitude for any given AEP should be considered in the application of the WSEs determined for a given flow probability.

\section{Example Map of 2010 Flood Inundation}

The updated hydraulic model was used to construct an example map of the 2010 flood inundated areas and the depth of flooding on the basis of the 0.2-percent AEP flow, which as previously noted is the estimated AEP of the 2010 flood in the
Pawtuxet River Basin. The example inundation map (fig. 5) for the Pawtuxet River is shown near the Warwick Wastewater Treatment Facility where the photograph in figure 6 was taken. The simulated depth of flooding near the entrance to the operations building (about $7.3 \mathrm{ft}$ ) corresponds to the height of the HWM above land surface shown in figure 6.

The flood-inundation map depth is determined by the HEC-RAS simulated WSE at each cross section and extrapolated between cross sections to develop a gridded water elevation map from which the LiDAR land-surface grid is subtracted. The resulting grid indicates the depth of flooding for each pixel within the inundated area. Inundation maps are designed to work interactively within a geographic information system (GIS), which can focus to an area of interest to examine flooding at specific locations.

The hydraulic models developed during this study could be used to develop maps of incremental flood inundation over a range of flows and corresponding stream stages near gaged reaches. Incremental flood inundation maps provide information on areas inundated at various flood magnitudes and could be incorporated into a Web-based map interface such as the USGS Flood Inundation Mapping Science Web site (http://water.usgs.gov/osw/flood_inundation/), which is designed to help communicate where flooding occurs. Whether a flood map is indexed to a USGS streamgage or just to a flood magnitude, the information can be used to assess flood risk and help plan for future flood events. For purposes of this investigation, however, only the magnitude of the 2010 flood was examined.

In this type of map, inundated areas as shown on figure 5 are for planning purposes only and are not intended for regulatory, permitting, or other legal purposes. The USGS provides these maps "as-is" for a quick reference, emergency planning tool but assumes no liability or responsibility from the use of this information. The actual inundated area and depth of water during the 2010 flood may differ from that shown because of debris, hydraulic model error, or elevation-data inadequacies. 


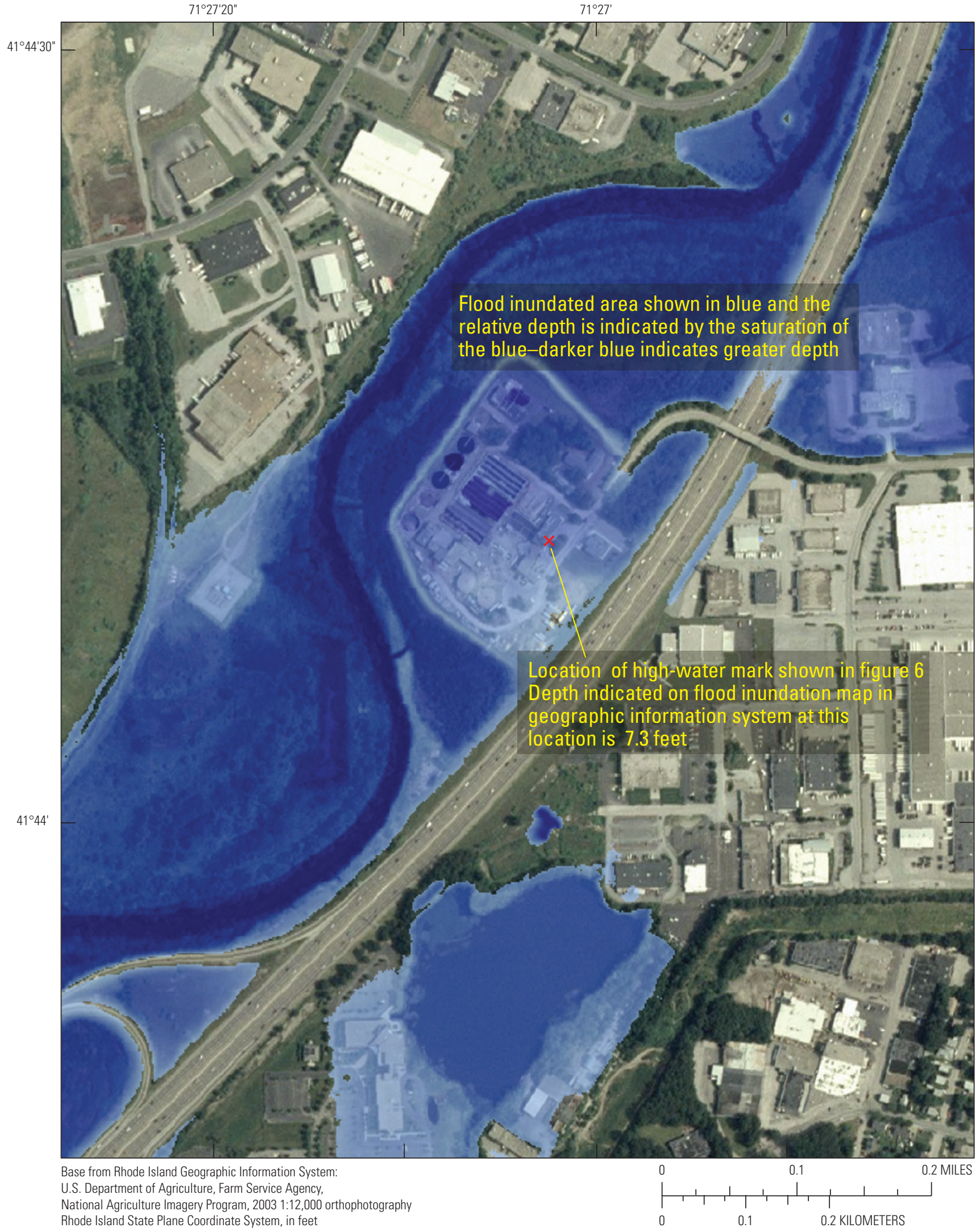

Figure 5. Flood inundation at the 0.2-percent annual exceedance probability along the Pawtuxet River near the Warwick Wastewater Treatment Facility in Rhode Island. 


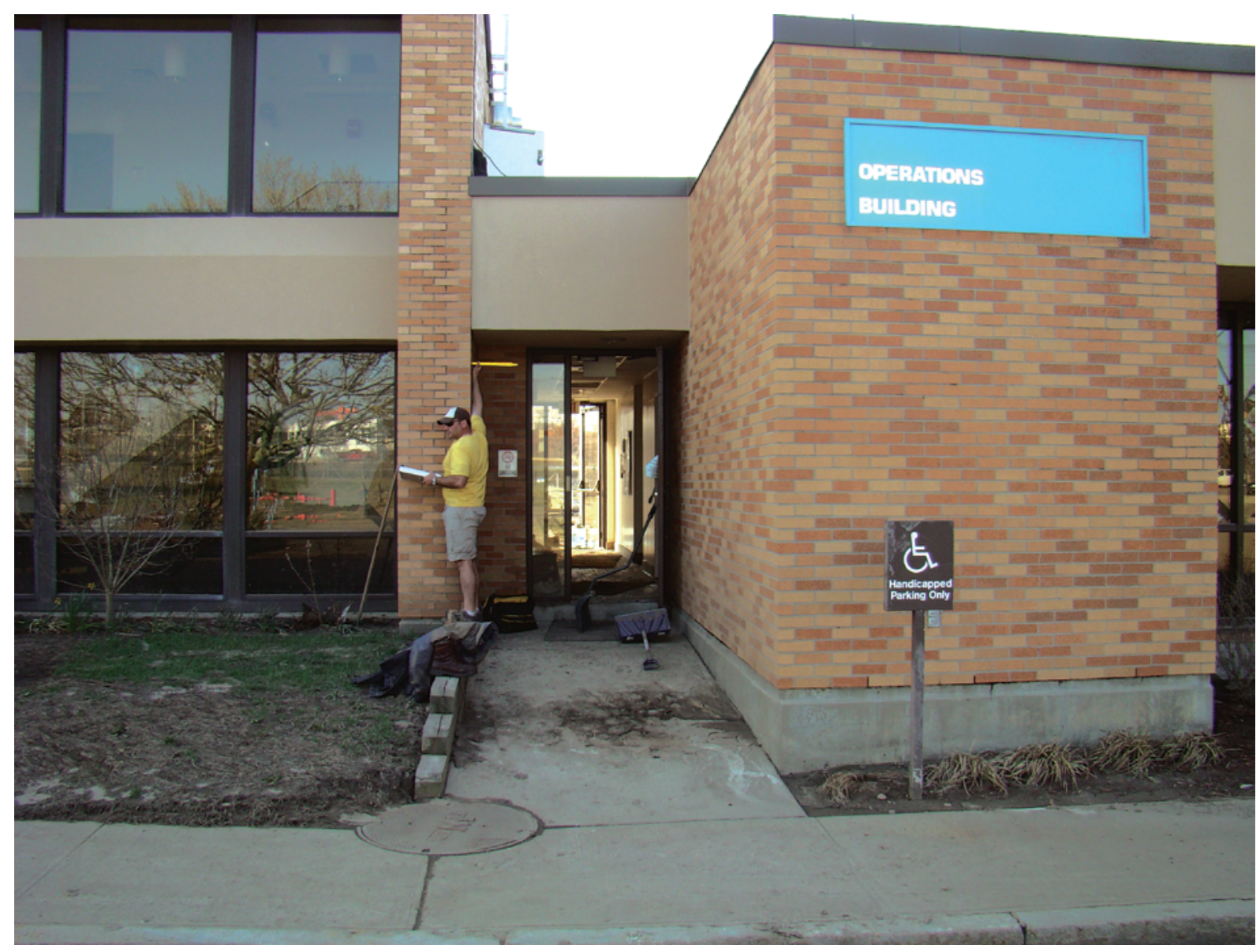

Figure 6. High-water mark on the operations building at the Warwick Wastewater Treatment Facility following the March-April 2010 flood near the Pawtuxet River, Rhode Island. 


\section{Summary and Conclusions}

On March 30, 2010, an Emergency Declaration was declared for Rhode Island (Rhode Island Severe Storms and Flooding (EM-3311), http://www.fema.gov/disasters/3311), following heavy, persistent rains from late February through March 2010. The rains caused severe flooding and set, or nearly set, record high streamflows and water levels at many long-term streamgages in the State. In August 2010, the U.S. Geological Survey (USGS) entered into an agreement with the U.S. Department of Homeland Security-Federal Emergency Management Agency (FEMA) to document and characterize the March-April 2010 flood. As part of that agreement, hydraulic models in selected river reaches of the Pawtuxet River Basin were updated to simulate water-surface elevations for specified flows, boundary conditions, and the reach carrying capacity or conveyance. The updated models along with that of previously developed models for flood insurance studies (FISs) were evaluated in comparison to high-water marks (HWMs) obtained following the MarchApril 2010 flood in a related USGS-FEMA study. Hydraulic models are an important tool for flood-plain management, transportation infrastructure design, FISs, and other purposes to help minimize future flood damages and risks.

The Pawtuxet River Basin covers an area of about 232 square miles $\left(\mathrm{mi}^{2}\right)$ in central Rhode Island that discharges into Pawtuxet Cove at the northern end of Narragansett Bay just south of the City of Providence. Hydraulic models were updated for about 56 river miles including the main stem of the Pawtuxet River (11.2 miles (mi)); North Branch Pawtuxet River (6.6 mi); South Branch Pawtuxet River (9.1 mi); nine tributaries reaches including Pocasset River (11.8 mi), Simmons Brook (3.6 mi), Dry Brook (3.0 mi), Meshanticut Brook (4.6 mi), Furnace Hill Brook (2.6 mi), Flat River (2.8 mi), Quidneck Brook (0.67 mi); and two unnamed tributaries referred to as South Branch Pawtuxet River Tributary A1 (0.52 mi), and South Branch Pawtuxet River Tributary A2 (0.04 mi). The hydraulic models of the Pocasset River and its tributaries-Simmons Brook and Dry Brook-recently developed (2006) by the Natural Resource Conservation Service (NRCS) were obtained and used in this study.

The hydraulic models were updated to Hydrologic Engineering Center-River Analysis System (HEC-RAS) version 4.1.0 using steady-state simulations. As part of the model updates riverine structures were surveyed at 27 dams, 48 bridges, and 36 culverts along the modeled reaches in the Pawtuxet River Basin, excluding those in the Pocasset River Basin reaches. The structural surveys generally included channel and bank profiles and the approach and exit to and from the structures to better reflect current (2011) conditions and to accurately georeference the structures in the model. Additional cross-section information was obtained from recently acquired light detection and ranging (LiDAR), which provides accurate land-surface elevation data.
Flood flows at the 10-, 2-, 1- and 0.5-percent annual exceedance probability (AEP) for gaged and ungaged sites were updated in the hydraulic models from the results and methods reported by Zarriello and others (2012), with the exception of the North Branch Pawtuxet River, which is ungaged and affected by upstream storage in the Scituate Reservoir. Consequently, the AEPs flows were determined by standard Bulletin 17B log-Pearson type-III methods from estimated annual peaks determined from the difference in peak flows at streamgages on the South Branch Pawtuxet River (01116000) and the Pawtuxet River (01116500), and adjusted for drainage area.

The flood flows used in the effective FIS (countywide updates were done for Providence in 2009 and Kent in 2010) generally are the same as the flood flows used in the original community FISs determined from a variety of methods that typically date back to the 1980s or earlier. In general, the updated AEP flows used in this study were substantially less (about 40 to 80 percent) than the flows determined by the TR-20 rainfall-runoff model and a 48-hour rainfall corresponding to the same AEP as the hydrologic flood. TR-20 derived flows were used in the Pocasset River and its tributaries, Simmons Brook and Dry Brook, and Meshanticut Brook and its tributary Furnace Hill Brook, but were updated in the 2006 NRCS model from revised estimates of total AEP rainfall. Flood flows determined by other methods used in the FIS typically were in closer agreement to the updated flows than the TR-20 derived flows, but still had a wide range of variability.

HWMs from the 2010 flood were obtained at 110 sites along the model reaches in the Pawtuxet River Basin mostly along the Pawtuxet, North Branch Pawtuxet, South Branch Pawtuxet, Pocasset, and Flat Rivers. The 2010 HWMs are estimated to have been caused by a flood with about a 0.2 -percent AEP on the basis of flood-frequency analysis of streamgages at Pawtuxet River at Cranston, R.I. (0116500), South Branch at Pawtuxet River at Washington, R.I. (0116000), and Nooseneck River at Nooseneck, R.I. (01115630). Differences between the 2010 HWMs and the simulated water-surface elevations (WSEs) at the 0.2-percent AEP in the effective FIS and the updated hydraulic models varied along the reaches, but in general, the updated model WSEs are in closer agreement with the 2010 HWMs than the effective FIS WSEs.

The updated hydraulic models developed in this study better represent the flood-water elevations, in general, than the effective FIS water-surface profiles at the 0.2-percent AEP as measured by the differences between these and the 2010 HWM elevations. The updated models also better represent current (2011) conditions and are consistent with high resolution digital land-surface elevation data. This study provides an assessment of the model for consideration in delineations of flood zones, flood-plain management operations, infrastructure design, and other purposes. It should be noted that the range of flows at the 95-percent confidence interval for a given AEP can produce appreciably different results than those simulated. 


\section{References Cited}

Bachand, J.A., Schmidt, Joel, Hardmeyer, Kent, Horter, Benjamin, and Carey, Constance, 2006, Pocasset River flood plain management study: Warwick, R.I., U.S. Department of Agriculture-Natural Resources Conservation Service, RI-TP-2006-1 [variously paged].

Brunner, G.W., 2010a, HEC-RAS river analysis system, user's manual (version 4.1): Davis, Calif., U.S. Army Corps of Engineers, Hydrologic Engineering Center, CPD-68, 766 p.

Brunner, G.W., 2010b, HEC-RAS river analysis system, hydraulic reference manual (version 4.1): Davis, Calif., U.S. Army Corps of Engineers, Hydrologic Engineering Center, CPD-69, 411 p.

DeGaetano, Art, and Zarrow, Dan, [n.d.], Extreme precipitation in New York \& New England Technical Manual: Ithaca, New York, Northeast Regional Climate Center Cornell University, ver. 1.12, 92 p. (available at http://precip.eas.cornell.edu/docs/xprecip_techdoc.pdf.)

FEMA - Federal Emergency Management Agency

FEMA, 1975, Flood Insurance Study, Town of West Warwick, Rhode Island: prepared by Tippetts-Abbett-McCarthyStratton Engineers and Architects, New York for the U.S. Department of Housing and Urban Development, Federal Insurance Administration, $34 \mathrm{p}$.

FEMA, 1978, Flood Insurance Study, Town of Coventry, Rhode Island: prepared by Anderson-Nichols and Company for the U.S. Department of Housing and Urban Development, Federal Insurance Administration, 47 p.

FEMA, 1980, City of Cranston, Rhode Island Flood Insurance Study: prepared by Harris-Toups Associates for the U.S. Department of Housing and Urban Development, Federal Insurance Administration, $47 \mathrm{p}$.

FEMA, 2009, Flood Insurance Study, Providence County, Rhode Island: no.44007CV001A, 3 v., 262 p.

FEMA, 2010, Flood Insurance Study, Kent County, Rhode Island: no. 44003CV001A, $132 \mathrm{p}$.

FEMA, 2011, Guidelines and standards for flood hazard mapping partners, Appendix M: Data capture standards, $170 \mathrm{p}$.

Heidemann, H.K., 2012, Lidar base specification version 1.0: U.S. Geological Survey Techniques and Methods, book 11, chap. B4, 63 p. (available at http://pubs.usgs.gov/tm/11b4/.)
Johnson, C.G., and Laraway, G.A., 1976, Flood magnitude and frequency of small Rhode Island streams: U.S. Geological Survey Open-File Report 76-883, 20 p.

Schmidt, Joel, Bachand, J.A., and Giaquinto, Clyde, 2007, Pocasset River flood plain management study: Warwick, R.I., U.S. Department of Agriculture-Natural Resources Conservation Service, RI-TP-2006-2, 37 p.

U.S. Army Corps of Engineers, 1991, HEC-2 Water surface profiles user's manual: Davis, Calif., U.S. Army Corps of Engineers, Hydrologic Engineering Center, 334 p.

U.S. Department of Agriculture, 1965, Computer program for project formulation-Hydrology: Washington, D.C., Soil Conservation Service, Engineering Division, Technical Release 20, 294 p.

U.S. Department of Agriculture, 1976, WSP-2 computer program: Washington, D.C., Soil Conservation Service, Engineering Division, Technical Release No. 61, 51 p.

U.S. Department of Commerce, 1961, Rainfall frequency atlas of the United States for durations from 30 minutes to 24 hours and return periods from 1 to 100 years: Washington, D.C., Weather Bureau, Technical Paper No. 40, 61 p.

U.S. Interagency Advisory Committee on Water Data, 1982, Guidelines for determining flood flow frequency: Reston, Va., U.S. Geological Survey, Office of Water Data Coordination, Bulletin 17B of the Hydrology Subcommittee, $183 \mathrm{p}$.

Weiss, L.A., 1975, Flood flow formulas for urbanized and non-urbanized areas of Connecticut: Watershed and Management Symposium, Irrigation and Drainage Division, American Society of Civil Engineers, August 11-13, 1975, Logan, Utah, p. 666.

Zarriello, P.J., Ahearn, E.A., and Levin, S.B., 2012, Magnitude of flood flows for selected annual exceedance probabilities in Rhode Island through 2010: U.S. Geological Survey Scientific Investigations Report 2012-5109, 93 p. (available at http://pubs.usgs.gov/sir/2012/5109/.)

Zarriello, P.J., and Bent, G.C., 2011, Elevation of the MarchApril 2010 flood high water in selected river reaches in Rhode Island: U.S. Geological Survey Open-File Report 2011-1029, 34 p. (available at http://pubs.usgs.gov/ ofr/2011/1029/.) 
THIS PAGE INTENTIONALLY LEFT BLANK 


\section{Appendix 1. Pawtuxet River Basin Hydraulic Models: Technical Data Support Notebook}

The hydraulic models developed in this study may be used to update Digital Flood Insurance Rate Map (DFIRM) by the U.S. Department of Homeland Security-Federal Emergency Management Agency (FEMA), but have not been approved for that purpose. As such, modifications to the models described in this report may be made prior to DFIRM production. 


\section{Background}

Following severe flooding during March-April 2010, the U.S. Geological Survey (USGS) and the U.S. Department of Homeland Security-Federal Emergency Management Agency (FEMA) entered into an agreement to characterize the hydrology and hydraulics of the event in selected parts of Rhode Island. In this study, hydraulic models of selected river reaches in the Pawtuxet River Basin were updated to Hydrologic Engineering Center-River Analysis System (HEC-RAS) version 4.1.0. Updates to the models included field surveys made at structures along the modeled reaches; incorporation of recent high resolution land-surface elevation data (LiDAR) acquired in November 2011; conversion of existing hydraulicmodel information, where needed; and updated flood flows at gaged and ungaged sites from a related study.
Reaches selected for detailed hydraulic analysis in the Pawtuxet River Basin were determined jointly by FEMA and the Rhode Island Emergency Management Agency. The Pawtuxet River, North Branch Pawtuxet River, South Branch Pawtuxet River, and nine tributary reaches were identified for analysis. Tributaries to the Pawtuxet River included the Pocasset River, Simmons Brook, Dry Brook, Meshanticut Brook, and Furnace Hill Brook; tributaries to the South Branch Pawtuxet River included Flat River, Quidneck Brook, and South Branch Pawtuxet River Tributaries A1 and A2 (fig. 1). Pawtuxet River Basin hydrology and hydraulic analyses are described in the flood insurance studies (FISs) for Kent County (FEMA, 2010; no. 44003CV001A) and Providence County (FEMA, 2009; no. 44007CV001A). The countywide FIS updates were compiled largely from earlier community FIS reports, which are summarized in table 1-1.

Table 1-1. Summary of updated hydraulic model reaches in the Pawtuxet River Basin and flood insurance studies (FIS) for each reach.

[The countywide FIS report supersedes all previous community FIS reports; S. Br., South Branch]

\begin{tabular}{|c|c|c|c|}
\hline Reach & FIS date & Community & Community number \\
\hline \multicolumn{4}{|c|}{ Effective (2013) FIS } \\
\hline See below & 2009 & Providence County, all jurisdictions & 44007 \\
\hline See below & 2010 & Kent County, all jurisdictions & 44003 \\
\hline \multicolumn{4}{|c|}{ Superseded community studies } \\
\hline \multirow[t]{3}{*}{ Pawtuxet River } & 1977,1986 & Town of West Warwick, Kent County & 440007 \\
\hline & 1977,1991 & City of Warwick, Kent County & 445409 \\
\hline & 1971,1984 & City of Cranston, Providence County & 445396 \\
\hline \multirow[t]{4}{*}{ North Branch Pawtuxet } & 1980 & Town of Scituate, Providence County & 440024 \\
\hline & 1971,1984 & City of Cranston, Providence County & 445396 \\
\hline & 1978 & Town of Coventry, Kent County & 440004 \\
\hline & 1977,1986 & Town of West Warwick, Kent County & 440007 \\
\hline \multirow[t]{2}{*}{ S. Br. Pawtuxet } & 1978 & Town of Coventry, Kent County & 440004 \\
\hline & 1977, 1986 & Town of West Warwick, Kent County & 440007 \\
\hline \multirow[t]{2}{*}{ Meshanticut Brook } & 1971,1984 & City of Cranston, Providence County & 445396 \\
\hline & 1977,1991 & City of Warwick, Kent County & 445409 \\
\hline Furnace Hill Brook & 1971,1984 & City of Cranston, Providence County & 445396 \\
\hline Flat River & 1978 & Town of Coventry, Kent County & 440004 \\
\hline Quidneck Brook & 1978 & Town of Coventry, Kent County & 440004 \\
\hline S. Br. Pawtuxet Tributary A1 & 2001 & Town of Coventry, Kent County & 440004 \\
\hline S. Br. Pawtuxet Tributary A2 & 2001 & Town of Coventry, Kent County & 440004 \\
\hline Pocasset River & 1971,1984 & City of Cranston, Providence County & 445396 \\
\hline Pocasset River & 1978, 1993 & Town of Johnston, Providence County & 440018 \\
\hline Simmons Brook & 1978 & Town of Johnston, Providence County & 440018 \\
\hline Dry Brook & 1978 & Town of Johnston, Providence County & 440018 \\
\hline
\end{tabular}


An updated hydraulic model for the Pocasset River and its tributaries - Simmons Brook and Dry Brook - was obtained from the Natural Resource Conservation Service (NRCS) and is reviewed in appendix 2 .

The updated hydraulic models were developed by the USGS for FEMA under Interagency Agreement number HSFEHQ-10-X-0672. The agreement began August 11, 2010, and ended March 30, 2013.

\section{Scope of Work}

This appendix provides information similar to FEMA (2011) Technical Support Data Notebook (TSDN) and includes details about the hydraulic model for selected reaches in the Pawtuxet River Basin in Providence and Kent Counties, Rhode Island, excluding the Pocasset River and its tributaries Simmons Brook and Dry Brook. The included reaches are the Pawtuxet River, North Branch Pawtuxet River, South Branch Pawtuxet River, Meshanticut Brook, Furnace Hill Brook, Flat River, Quidneck Brook, and South Branch Pawtuxet River Tributaries A1 and A2. Additional information on the Pocasset River Basin hydraulic model is provided in appendix 2.

\section{Pawtuxet River}

The Pawtuxet River begins where it discharges into Pawtuxet Cove, a tidal embayment at the northern end of Narragansett Bay just south of the City of Providence and ends 11.2 miles (mi) upstream at the confluence of the North and South Branches of the Pawtuxet Rivers in the Town of West Warwick (fig. 1). The river flows east-northeast through the Town of West Warwick and forms the boundary between the cities of Warwick and Cranston.

\section{North Branch Pawtuxet River}

The North Branch Pawtuxet River begins at the confluence with the South Branch of the Pawtuxet River and ends 6.6 mi upstream at the outlet of the Scituate Reservoir in the southeastern part of the Town of Scituate (fig. 1). The river flows southeast through the towns of Scituate, Coventry, and West Warwick and the City of Cranston.

\section{South Branch Pawtuxet River}

The South Branch Pawtuxet River begins at the confluence with the North Branch Pawtuxet River and ends $9.1 \mathrm{mi}$ upstream at the outlet of Flat River Reservoir, in the centraleastern part of the Town of Coventry (fig. 1). The South Branch Pawtuxet River meanders east-northeast through the towns of Coventry and West Warwick.

\section{Meshanticut Brook}

Meshanticut Brook begins at its confluence with Pawtuxet River and ends 4.6 mi upstream at Scituate Avenue in the north-central part of the City of Cranston. The brook flows south along the Interstate 295 (I-295) corridor to the Pawtuxet River mostly through the City of Cranston and a small segment of the lower reach flows through the City of Warwick.

\section{Furnace Hill Brook}

Furnace Hill Brook is in the northwest corner of the City of Cranston and is a tributary to Meshanticut Brook. The brook flows south, then east, to its confluence with Meshanticut Brook. The 2.6-mi model reach starts at its confluence with Meshanticut Brook and ends at Pippen Orchard Road.

\section{Flat River}

Flat River is in the north-central part of the Town of Coventry and runs eastward where it discharges to the Flat River Reservoir. The 2.8-mi model reach starts at its mouth at Flat River Reservoir and ends below the confluence with Pine Swamp Brook at Flat River Road.

\section{Quidneck Brook}

Quidneck Brook flows into Stump Pond and then into the Flat River Reservoir in the central part of the Town of Coventry. The 0.7-mi model reach starts at it mouth at Flat River Reservoir and ends at Stump Pond.

\section{South Branch Pawtuxet River Tributary A1}

Tributary A1 is a minor tributary that drains to the South Branch Pawtuxet River about a 1 mi downstream from Flat River Reservoir. The tributary is small enough that a stream centerline does not appear in the 1:24,000 scale National Hydrography Dataset (NHD). The 0.44-mi model reach starts at its confluence with the South Branch Pawtuxet River and ends at Flat River Road.

\section{South Branch Pawtuxet River Tributary A2}

Tributary A2 is a minor tributary (not shown in the 1:24,000 scale NHD) that drains to the South Branch Pawtuxet River just downstream from Tributary A1. The 0.04-mi model reach starts at its confluence with the South Branch Pawtuxet River and ends upstream of a rail trail (abandoned railroad) culvert. 


\section{Engineering Analyses}

The engineering analyses include hydrologic and hydraulic analyses. The hydrologic analysis provides the magnitude of flood flows specified in the hydraulic models. The hydraulics analysis is the development of the hydraulic model used to simulate the water-surface elevation (WSE) for a specified flood flow.

\section{Hydrologic Analyses}

Most hydrologic analyses used in this study were from updated annual exceedance probability (AEP) flood flows at streamgages and regional flood-flow equations for ungaged streams developed in a related USGS-FEMA study by Zarriello and others (2012). Flows at streamgages for 10-, 2-, 1-, and 0.2-percent AEP floods were determined by the standard log-Pearson type-III method described in Bulletin 17B of the Hydrology Subcommittee (U.S. Interagency Advisory Committee on Water Data, 1982) and a modification of this method known as the expected moments algorithm (EMA). The regional flood-flow equations developed from the at-site analysis were used to estimate flood flows at ungaged sites in the Pawtuxet River Basin except for the South Branch Pawtuxet River and the Pawtuxet River, which have long-term streamgages, and the North Branch Pawtuxet River. The report by Zarriello and others (2012) provides equations for adjusting flood flows at ungaged sites on a gaged streams, which were used for estimating flows in the South Branch and main stem Pawtuxet River reaches.

Flows specified in HEC-RAS are used in the model from upstream to downstream until a new flow is specified. Specified flows typically were determined at transition points where the drainage area changes appreciably, such as at the confluence with a large tributary. For example, the flow in the reach above the tributary would be determined from the drainage area just above the confluence and used as the flow in the reach above the tributary until the next large tributary. The process would repeat until representative flows are determined for the model reach. The drainage area reported in the tables that follow were generally determined at the downstream end of the reach where the flow applies, as described above; however, the cross section (and description) specified in each of the reach tables is at an upstream end of where the flow is first specified.

\section{Pawtuxet River}

The AEP flood flows for the Pawtuxet River were determined from streamgage records at the Cranston (01116500) from 1939 through 2010 using the EMA method and historical information from the 1886 flood (Zarriello and others, 2012). The discharges above and below the streamgage (table 1-2) were adjusted from the gaged location using a drainage area ratio method (Zarriello and others, 2012).

\section{North Branch Pawtuxet River}

Flow in the North Branch Pawtuxet River is affected by the Scituate Reservoir. To estimate flood flows in this reach a flood-frequency analysis was done using standard Bulletin 17B log-Pearson type-III methods (U.S. Interagency Advisory Committee on Water Data, 1982) of estimated annual peak flows for the reach. Annual peak flows were estimated by subtracting the streamgage annual peak flows at the South Branch Pawtuxet River (01116000) from the concurrent annual peak flows at the Pawtuxet River (01116500). The resulting flow was adjusted by the drainage area ratio $(0.788)$ of the North Branch at the confluence (drainage area is 108 square miles $\left.\left(\mathrm{mi}^{2}\right)\right)$ to the intervening area difference between the South Branch $\left(62.8 \mathrm{mi}^{2}\right)$ and the Pawtuxet River $\left(200 \mathrm{mi}^{2}\right)$ streamgages $[108 /(200-62.8)=0.788]$.

Table 1-2. Annual exceedance probability flood flows specified in the hydrologic model for the Pawtuxet River, Rhode Island.

$\left[\mathrm{ft}^{3} / \mathrm{s}\right.$, cubic feet per second; $\mathrm{mi}^{2}$, square mile]

\begin{tabular}{|c|c|c|c|c|c|c|c|}
\hline \multirow{2}{*}{ Description } & \multicolumn{2}{|c|}{ Cross section station } & \multirow{2}{*}{$\begin{array}{l}\text { Drainage area }{ }^{1} \\
\qquad\left(\mathrm{mi}^{2}\right)\end{array}$} & \multicolumn{4}{|c|}{$\begin{array}{l}\text { Discharge }\left(\mathrm{ft}^{3} / \mathrm{s}\right) \text { for specified percent } \\
\text { annual exceedance probability }\end{array}$} \\
\hline & From & To & & 10 & 2 & 1 & 0.2 \\
\hline Below Meshanticut Brook & 48,954 & 25,331 & 201 & 3,840 & 6,940 & 8,820 & 15,000 \\
\hline Above Pocasset River confluence & 23,622 & 23,622 & 202 & 3,860 & 6,970 & 8,850 & 15,060 \\
\hline
\end{tabular}

${ }^{1}$ The drainage area is the downstream point ("To" station) where the flow was determined; the "From" station and "Description" is the upstream point where the flow is first specified. 
Streamgage peak flow records indicate that some of the annual peaks from the South Branch Pawtuxet River and Pawtuxet River streamgages were not coincident (meaning they did not occur around the same date). Hence, the assumption was made that the peak flow on the North Branch Pawtuxet River would be coincident with the peak flow on the Pawtuxet River and therefore, the South Branch peak flow needed to be coincident with these peak flows. To ensure that the South Branch peak flows were coincident with the Pawtuxet River peaks, a regression model was developed using SAS version 9.1.3 (SAS Institute, Inc., 1990) to estimate instantaneous peak flows from daily flow values at the South Branch streamgage by:

$$
\text { PeakQ }=0.9488(Q)^{1.023}
$$

where

$$
\begin{gathered}
\text { PeakQ = } \begin{array}{c}
\text { instantaneous peak flow at South Branch } \\
\text { Pawtuxet River }(01116000), \text { and }
\end{array} \\
\text { Q } \begin{array}{c}
\text { maximum daily peak flow coincident } \\
\text { with the annual peak at Pawtuxet River } \\
(01116500) .
\end{array}
\end{gathered}
$$

The adjusted coefficient of determination (adj- $\left.-\mathrm{r}^{2}\right)$ for the regression was 0.98 , which was determined from 70 annual peak flows and the coincident daily flow at the South Branch Pawtuxet River streamgage.

The non-coincident annual peak flows in the South Branch were estimated from equation 1, subtracted from the annual peak at Pawtuxet River streamgage, and adjusted by the drainage area ratio to compute annual peak flows. The coincident and non-coincident annual peaks were determined from 1941 to 2010. The complete annual peak flow series for the North Branch Pawtuxet River was then used to compute a log-Pearson type-III probability distribution using PeakFQ (Flynn and others, 2006). The flow magnitudes for the select AEP floods for the North Branch Pawtuxet River are listed in table 1-3. A single flow for a given AEP was specified for the model reach as the drainage area at the upstream end of the reach $\left(94.3 \mathrm{mi}^{2}\right)$ is only about 13 percent less than the drainage area at the downstream end of the reach $\left(108 \mathrm{mi}^{2}\right)$.

Table 1-3. Annual exceedance probability flood flows specified in the hydrologic model for the North Branch Pawtuxet River, Rhode Island.

[ft $\mathrm{ft}^{3} \mathrm{~s}$, cubic feet per second; $\mathrm{mi}^{2}$, square mile]

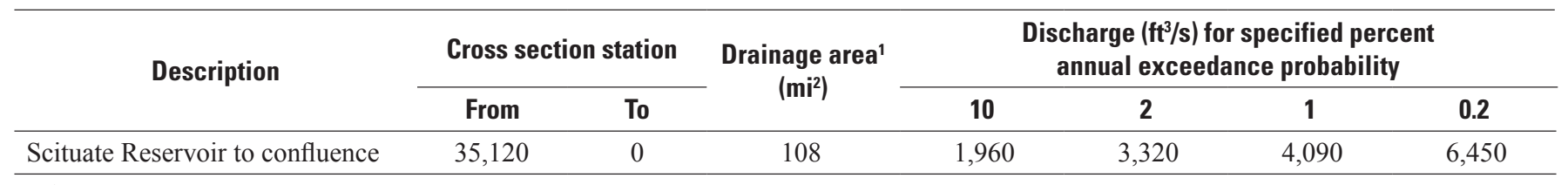

'The drainage area is the downstream point ("To" station) where the flow was determined; the "From" station and "Description" is the upstream point where the flow is first specified.

\section{South Branch Pawtuxet River}

The South Branch Pawtuxet River AEP flood flows were determined from the streamgage at Washington, R.I. (01116000), annual peak flows for 1941-2010, weighted by regional-regression equation values to improve the estimated magnitude of the AEP flow (Zarriello and others, 2012). The flood magnitudes at the streamgage were adjusted for the other specified locations (table 1-4) using the Guimaraes-Bohman approach (Zarriello and others, 2012), which is a modified version of a drainage area ratio adjustment, but also incorporates the regional-regression equation estimated flows at the ungaged location.

\section{Flat River, Furnace Hill Brook, Meshanticut Brook, and Quidneck Brook}

The flood flows specified for the Flat River, Furnace Hill Brook, Meshanticut Brook, and Quidneck Brook HEC-RAS models (table 1-5) were determined from regional flood-flow regression equations by Zarriello and others (2012). Flows for a bypass channel for Meshanticut Brook are specified at the 0.2-percent AEP at Wilbur Avenue when excessive pooling caused by the constriction at the I-295 culvert results in water flowing down Wilber Avenue under I-295 and then rejoining Meshanticut Brook downstream of the I-295 culvert. The flow in the bypass was determined by running the model in the optimization mode, then specifying the computed diversion in the 0.2 -percent flow simulation. 
Table 1-4. Annual exceedance probability flood flows specified in the hydrologic model for the South Branch Pawtuxet River, Rhode Island.

$\left[\mathrm{ft}^{3} / \mathrm{s}\right.$, cubic feet per second; $\mathrm{mi}^{2}$, square mile; USGS, U.S. Geological Survey; ft, feet]

\begin{tabular}{|c|c|c|c|c|c|c|c|}
\hline \multirow{2}{*}{ Description } & \multicolumn{2}{|c|}{ Cross section station } & \multirow{2}{*}{$\begin{array}{l}\text { Drainage area }{ }^{1} \\
\qquad\left(\mathrm{mi}^{2}\right)\end{array}$} & \multicolumn{4}{|c|}{$\begin{array}{l}\text { Discharge }\left(\mathrm{ft}^{3} / \mathrm{s}\right) \text { for specified percent } \\
\text { annual exceedance probability }\end{array}$} \\
\hline & From & To & & 10 & 2 & 1 & 0.2 \\
\hline At USGS streamgage (01116000) & 35,496 & 21,788 & 62.8 & 1,500 & 2,620 & 3,180 & 4,680 \\
\hline About $10,000 \mathrm{ft}$ below Tiogue Lake outlet & 21,343 & 17,538 & 68.4 & 1,620 & 2,800 & 3,380 & 4,930 \\
\hline
\end{tabular}

${ }^{1}$ The drainage area is the downstream point ("To" station) where the flow was determined; the "From" station and "Description" is the upstream point where the flow is first specified.

Table 1-5. Annual exceedance probability flows specified in the hydrologic models for the Flat River, Furnace Hill Brook, Meshanticut Brook, and Quidneck Brook, Rhode Island.

$\left[\mathrm{ft}^{3} / \mathrm{s}\right.$, cubic feet per second; $\mathrm{mi}^{2}$, square mile; ft, feet; --, not applicable $]$

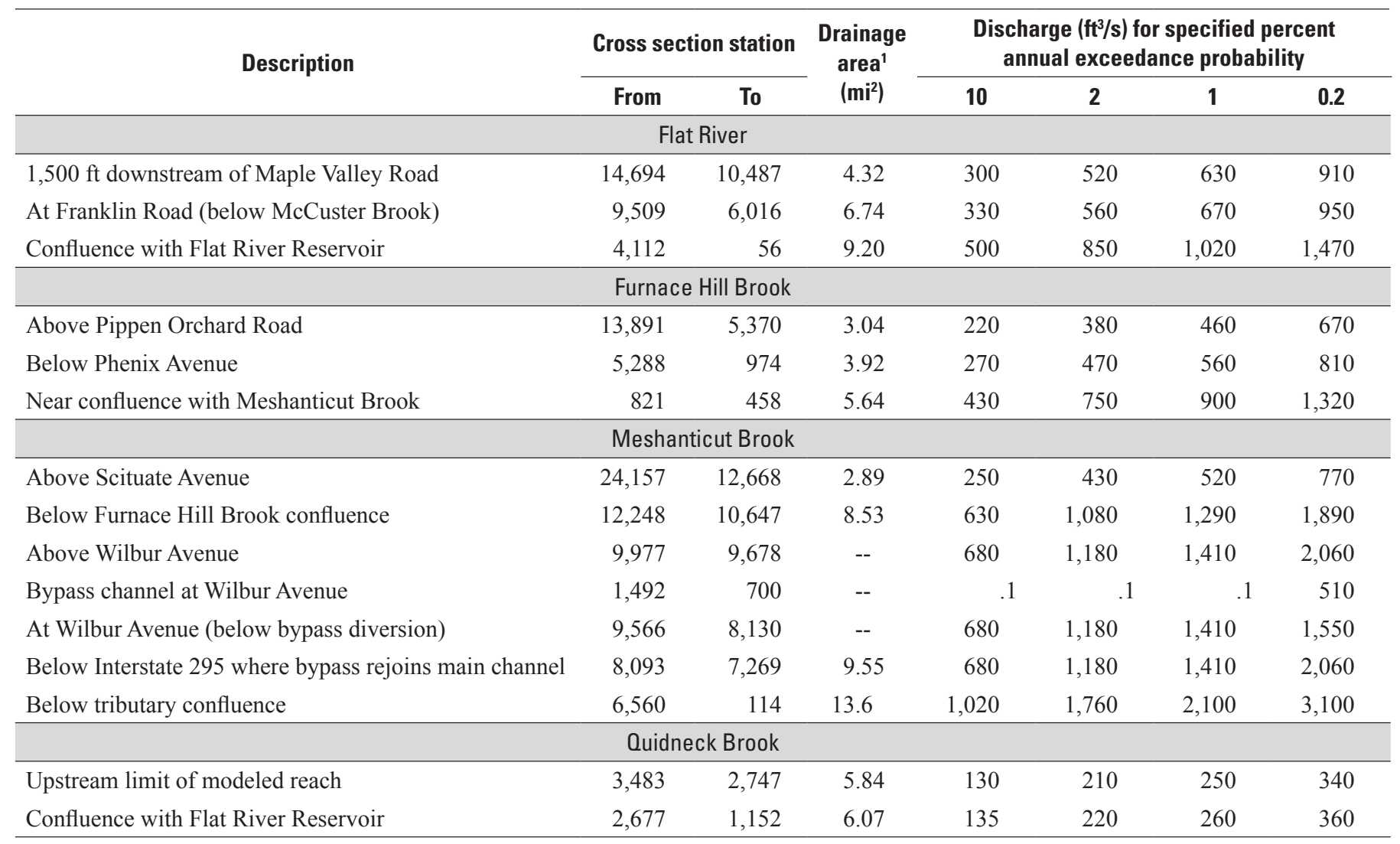

'The drainage area is the downstream point ("To" station) where the flow was determined; the "From" station and "Description" is the upstream point where the flow is first specified. 


\section{South Branch Pawtuxet River Tributaries A1 and} A2

The AEP flood flows specified for the South Branch Pawtuxet River Tributaries A1 and A2 (table 1-6) are outside the applicable limits of the regional flood-flow regression equations developed for Rhode Island (Zarriello and others, 2012). Flows for these tributaries were estimated by a simple drainage area ratio by adjusting the AEP flows determined from the regional-regression equations for the Flat River at the upstream end of the reach (below Maple Valley Road) where the drainage area is near the lower limit of the regional flow equations and the basin characteristics are similar to the tributary A1 and A2 characteristics.

\section{Hydraulic Analyses}

Hydraulic analyses of selected reaches were done using HEC-RAS version 4.1.0 (Brunner, 2010a, b). The initial scope of the study was to update the existing FIS hydraulic models to HEC-RAS. Early in the study, it became apparent that the river conveyance was not always representative of current conditions. In addition, a simple conversion of the model could cause other problems, such as improper georeferencing riverine structures. The study was modified to improve the representativeness of the river hydraulic models by collecting field survey data and the use of recent (2011) LiDAR data. Field survey data and LiDAR data were incorporated into the updated models using the HEC-GeoRAS (Ackerman, 2011) plug-in to ArcMAP, which allows the exchange of georeferenced information with the HEC-RAS model.

Table 1-6. Annual exceedance probability flows specified in the hydrologic models for South Branch Pawtuxet River Tributaries A1 and $A 2$, Rhode Island.

$\left[\mathrm{ft}^{3} / \mathrm{s}\right.$, cubic feet per second; $\mathrm{mi}^{2}$, square mile]

\begin{tabular}{|c|c|c|c|c|c|c|c|}
\hline \multirow[t]{2}{*}{ Description } & \multicolumn{2}{|c|}{ Cross section station } & \multirow{2}{*}{$\begin{array}{l}\text { Drainage area' } \\
\qquad\left(\mathrm{mi}^{2}\right)\end{array}$} & \multicolumn{4}{|c|}{$\begin{array}{c}\text { Discharge }\left(\mathrm{ft}^{3} / \mathrm{s}\right) \text { for specified percent } \\
\text { annual exceedance probability }\end{array}$} \\
\hline & From & To & & 10 & 2 & 1 & 0.2 \\
\hline Below abandoned railroad bed (rail trail) & 2,746 & 396 & .73 & 50 & 90 & 110 & 150 \\
\hline \multicolumn{8}{|c|}{ South Branch Pawtuxet River Tributary A2 } \\
\hline
\end{tabular}

After the initial hydraulic model simulations were done, the error and warning messages generated by HEC-RAS and FEMA's CHECK-RAS application were reviewed. The results were assessed for validity, accuracy, and appropriate engineering practices. Some of the areas of concern included the critical water-surface calculations, WSE differences between adjacent cross sections, and correct usage of ineffective-flow areas. After revisions were made to the model, the model was run again and the results were reviewed; the process was repeated until the remaining warnings were judged acceptable.

\section{Solution Check at Bridges and Culverts}

During high-flow conditions, pressure flow may occur at bridges and culverts when the water surface on the upstream side of the structure equals or exceeds the low chord of the bridge or the top of the culvert. The possibility of this type of condition was checked at all bridges and culverts where the
WSE derived from the energy equation was found to be near the low chord of a bridge or the top of the culvert. Although the energy-equation method is applicable to the widest range of hydraulic problems (Brunner, 2010b), pressure-flow computations are needed when the water surface comes into contact with the low bridge chord or top of the culvert. In a number of cases, pressurized flow is controlled by the downstream WSE, and a coefficient for the applicable flow equation is specified.

During high-flow conditions, road overflow may occur, which results in weir flow if the structure is not submerged (sufficient drop in the water surface on the downstream side of the structure). Submergence is determined as a function of the ratio of the downstream flow depth to the upstream energy grade line, as measured from the minimum high chord of the bridge deck (Warner and others, 2010). The HEC-RAS uses a default maximum submergence ratio of 0.95 for weir-flow calculations. When the 0.95 ratio is exceeded, HEC-RAS Applications Guide (Warner and others, 2010) states: 
"When this ratio is exceeded for a bridge analysis, the program will switch from the weir-flow equation to the energy method to determine the upstream flow depth. For a culvert analysis, this ratio is not used because the program cannot perform a backwater analysis through a culvert flowing full. Therefore, a weir analysis will always be used when overflow occurs."

As a result, when road overflow occurs at a culvert and the weir-flow computation is determined to be invalid, other modeling techniques are used to account for an energy-based solution. For this condition, the roadbed does not act like a weir and a weir-flow coefficient for submergence is used.

\section{Pawtuxet River}

A HEC-RAS model was developed for the entire $11.2 \mathrm{mi}$ of the Pawtuxet River from the mouth to confluence of the North and South Branches (fig. 1-1). The model was developed from (1) cross-section and riverine structure data surveyed in the field by the USGS, (2) the effective FIS, (3) a HEC-RAS model developed for the lower part of the river (4.6 mi reach above the mouth) as part of the assessment of the Pawtuxet River Dam removal (Milone $\&$ MacBroom, Inc., 2008; EA Engineering, Science, and Technology, Inc., 2010), (4) a HEC-RAS model and study of anadromous fish passage in the Pawtuxet River (Kleinschmidt Energy \& Water Resource Consultants, 2005), and (5) 2011 LiDAR data. Peak discharges estimated for 10-, 2-, 1-, and 0.2 -percent AEP floods were used with cross-sectional and riverine structure information to compute the corresponding water-surface profiles.

\section{Model Limit and Baseline Stationing}

The Pawtuxet River model starts at the mouth at Pawtuxet Cove and ends at the confluence of the North and South Branches of the Pawtuxet River. Stationing for the model is referenced in feet upstream from the mouth of the river about 300 feet (ft) downstream from Broad Street.

\section{Cross-Section and Structural-Geometry Data}

The Pawtuxet River hydraulic model consists of 184 cross sections, 17 bridges, and 4 dams (table 1-7). The USGS surveyed 18 riverine structures, 14 approaches, and 10 exits for the model; other cross sections were obtained from the effective FIS and the HEC-RAS models (46 cross sections) developed for the Pawtuxet River Dam removal assessment (Milone \& MacBroom, Inc., 2008; EA Engineering, Science, and Technology, Inc., 2010; Kleinschmidt Energy \& Water Resource Consultants, 2005). Elevations from LiDAR data were used to supplement or extend the surveyed cross sections as needed. All survey and model data are referenced to
North American Datum of 1983 (NAD 83) horizontal datum and North American Vertical Datum of 1988 (NAVD 88) vertical datum.

No synthetic cross sections were generated for the model. However, sections at the upstream and downstream faces of structures were sometimes interpolated from the approach and exit cross sections, and the structure geometry. Levees, ineffective-flow areas, and obstructions were specified in channel cross sections as needed.

Table 1-7. Summary of cross sections in the hydraulic model for Pawtuxet River, Rhode Island.

[Available separately at http://pubs.usgs.gov/sir/2013/5192/ appendix/sir2013-5192_apend01.xls]

\section{Starting Water-Surface and Backwater Elevation}

The Pawtuxet River is affected by backwater from Pawtuxet Cove, a small embayment to Narragansett Bay. A WSE of $6.82 \mathrm{ft}$. (NAVD 88) was used as the starting boundary condition for all AEP simulations, which corresponds to the 10-year high tide at Pawtuxet Cove. The tide elevation was determined from the 10-year tide ( $7.23 \mathrm{ft} \mathrm{NAVD} 88$ ) at Providence by the generalized logistic distribution fit (GLO) (MOD, 2008) and updated from information in a STARR report to FEMA (Timothy Hillier, CDM Smith, STARR Coastal Processes Lead, written commun., 2010) then adjusted for difference in tide between Providence $(-0.41 \mathrm{ft})$ and Pawtuxet Cove from tide profiles reported by the U.S. Army Corps of Engineers (1988).

\section{Manning's Roughness Coefficients}

Manning's roughness coefficients (n) for the main channel and overbank areas of the Pawcatuck River were largely obtained from the existing FIS hydraulic model. Some adjustments to the " $n$ " values were made from field observations and aerial photographs and by comparing the observed 2010 flood HWMs to the HEC-RAS model results. Manning's roughness coefficients range in value from 0.035 to 0.045 with a median of 0.041 for the main channel, and from 0.040 to 0.100 for the overbank areas with a median of 0.070 .

\section{Flow Lengths}

Main-channel and overbank-flow lengths were computed through the use of HEC-GeoRAS. Flow paths were defined by the NHD stream centerline and by the modeler for the overbanks. The main-channel length between cross sections ranged from 6 to 4,552 ft with a median length of $324 \mathrm{ft}$; lengths on the left and right banks were similar to the main channel. Short and long channel lengths typically are caused by meanders in the river. 


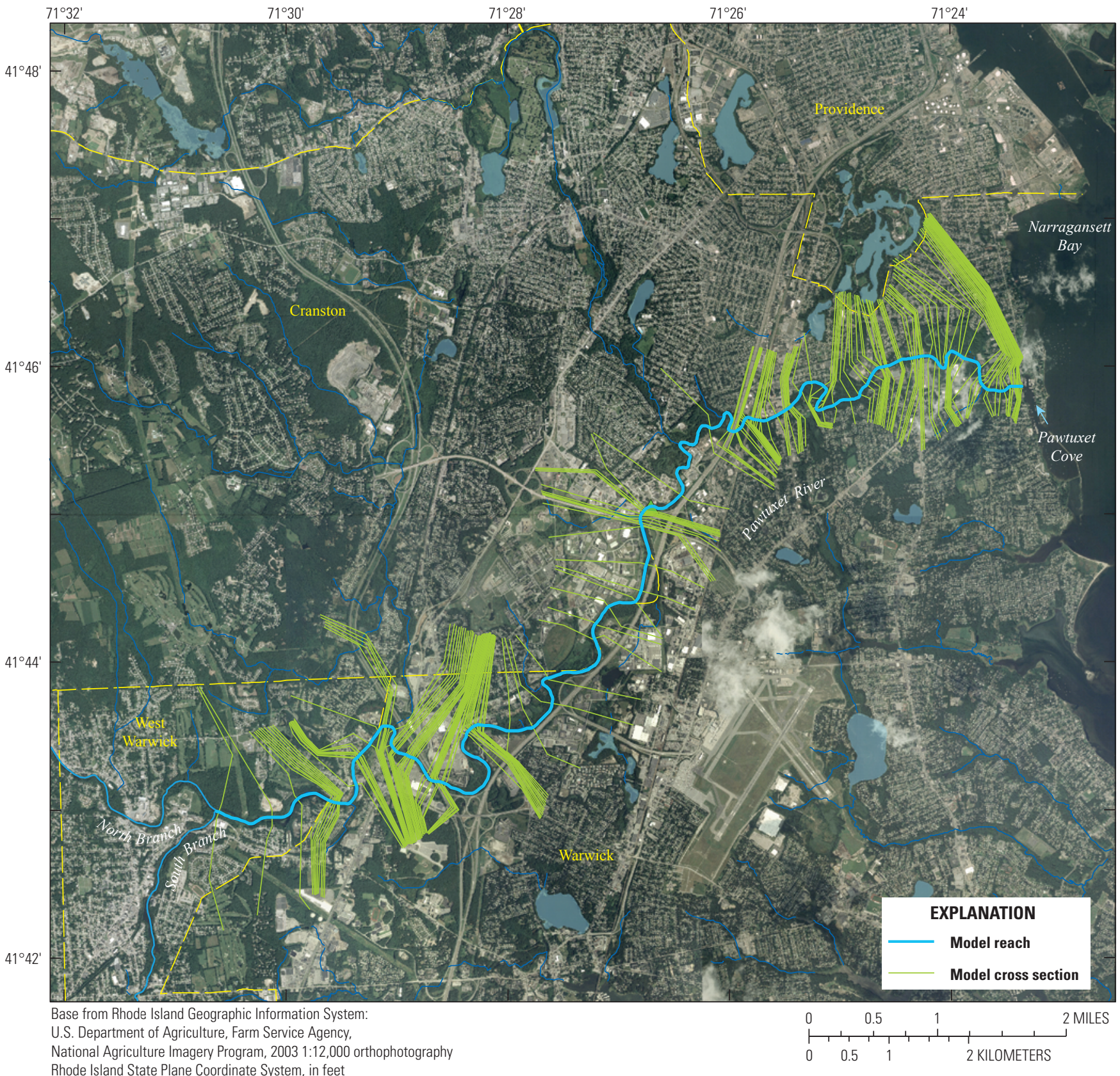

Figure 1-1. Hydraulic model reach for the Pawtuxet River, Rhode Island. 


\section{Hydraulic Structures}

Water levels in the Pawtuxet River can be affected by 17 bridges and 4 dams. The most downstream dam, Pawtuxet River Dam, just upstream from the mouth above Broad Street, was built in 1924 on a rock outcropping (Milone \& MacBroom, Inc., 2008) but was removed in late August 2011. The field surveys of this reach were made prior to the dam removal; therefore, the dam, albeit small, is still reflected in the model.

Table 1-8 lists the type of structures and the solution type used at bridges to compute the flood profile for the 1-percent AEP flow. Road overflow at the 1-percent AEP flow is noted. The solution type at bridges was determined by the model on the basis of the simulated conditions at the structure, which can vary according to the AEP flow.

\section{North Branch Pawtuxet River}

A HEC-RAS model was developed for the entire $6.6 \mathrm{mi}$ reach of the North Branch Pawtuxet River from its confluence with the South Branch Pawtuxet River to the outflow of Scituate Reservoir (fig. 1-2). The model was developed from cross-section and riverine-structure data surveyed in the field by the USGS, the effective FIS models, and 2011 LiDAR data. Information obtained from the effective FIS models for the North Branch Pawtuxet River was from two separate models of the upper and lower reaches (3.0 and $1.9 \mathrm{mi}$ in length, respectively) separated by about a $1.1 \mathrm{mi}$ reach that was not modeled. Peak discharges estimated for 10-, 2-, 1-, and 0.2-percent AEP floods were used with cross-sectional and riverine-structure information to compute the corresponding water-surface profiles. Ineffective flow areas and obstructions were specified as needed.

Table 1-8. Summary of structures in the hydraulic model for the Pawtuxet River, Rhode Island.

[River station rounded to the nearest foot; AEP, annual exceedance probability; Inl Struct, in line structure; --, not applicable; WSPRO, computer model for Water Surface Profile computations, Federal Highway Administration, 1990]

\begin{tabular}{|c|c|c|c|c|}
\hline \multirow{2}{*}{$\begin{array}{l}\text { River station } \\
\text { (feet) }\end{array}$} & \multirow{2}{*}{ Description } & \multirow{2}{*}{ Structure type } & \multicolumn{2}{|c|}{ 1-percent AEP flow } \\
\hline & & & Road overflow & Solution type \\
\hline 328 & Broad Street & Bridge & No & Energy \\
\hline 463 & Pawtuxet River Dam & Inl Struct & -- & Weir \\
\hline 6,064 & Warwick Avenue (Route 117) & Bridge & No & Energy \\
\hline 7,645 & Conrail no. 2 railroad & Bridge & Yes & Energy \\
\hline 14,405 & Elmwood Avenue & Bridge & Yes & Pressure and weir \\
\hline 15,889 & Conrail \#1 railroad & Bridge & No & Energy \\
\hline 16,908 & Interstate 95 & Bridge & No & Energy \\
\hline 25,701 & Route 37 north span & Bridge & No & Energy \\
\hline 25,988 & Route 37 south span & Bridge & No & WSPRO \\
\hline 40,118 & Unnamed small dam & Inl Struct & -- & Weir \\
\hline 40,262 & Pontiac Dam & Inl Struct & -- & Weir \\
\hline 40,645 & Greenwich Avenue (Route 5) & Bridge & No & Energy \\
\hline 45,652 & Interstate 295 east span & Bridge & No & Energy \\
\hline 45,806 & Interstate 295 west span & Bridge & No & Energy \\
\hline 47,360 & Bald Hill Road (Route 2) southeast span & Bridge & No & Energy \\
\hline 47,441 & Bald Hill Road (Route 2) northeast span & Bridge & No & Energy \\
\hline 48,137 & Route 2 ramp & Bridge & No & Energy \\
\hline 49,524 & Washington Trail (old railroad) & Bridge & No & Energy \\
\hline 51,190 & East Avenue & Bridge & Yes & Energy and weir ${ }^{1}$ \\
\hline 53,736 & Natick Pond Dam & Inl Struct & -- & Weir \\
\hline 53,924 & Providence Street (Route 33) & Bridge & No & Energy \\
\hline
\end{tabular}

${ }^{1}$ Pressure and weir flow at the 0.2-percent AEP flow. 


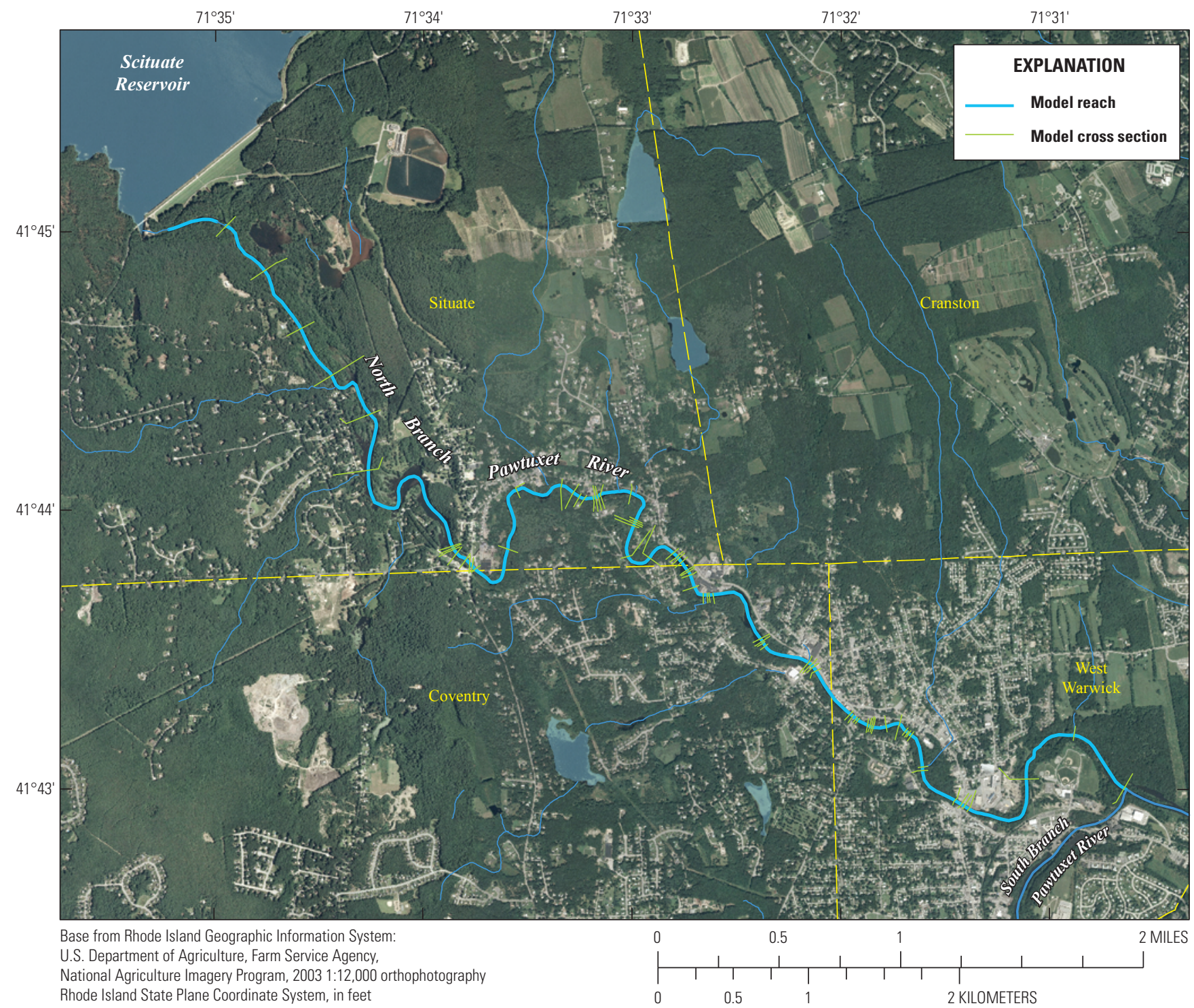

Figure 1-2. Hydraulic model reach for the North Branch Pawtuxet River, Rhode Island.

\section{Model Limit and Baseline Stationing}

The North Branch Pawtuxet River starts at its confluence with the South Branch Pawtuxet River and ends just below the outlet of Scituate Reservoir. Stationing is referenced in feet upstream from the confluence of the north and south branches.

\section{Cross-Section and Structural-Geometry Data}

The North Branch Pawtuxet River model consists of 74 cross sections, 7 bridges, and 6 dams (table 1-9). Note that the contracted openings from two railroad-bridge abutments were included in the model but were not modeled as bridges because of the height of the low cord above the river. The
USGS surveyed 14 riverine structures, 13 approaches, and 14 exits; other cross sections were obtained from the effective FIS. Elevations from LiDAR data were used to supplement or extend the surveyed cross sections as needed. All survey and model data are referenced to NAD 83 horizontal datum and NAVD 88 vertical datum.

No synthetic cross sections were generated for the model. However, sections at the upstream and downstream faces of structures were interpolated from the overbank sections to the approach and exit cross sections, and the channel points of the structure geometry. Ineffective flow areas were specified in channel cross sections as needed. 
Table 1-9. Summary of cross sections in the hydraulic model for the North Branch Pawtuxet River, Rhode Island.

\section{[Available separately at http://pubs.usgs.gov/sir/2013/5192/ appendix/sir2013-5192_apend01.xls]}

\section{Starting Water-Surface and Backwater Elevation}

The starting WSE at the confluence with the South Branch Pawtuxet River was determined from the computed WSE at the upstream end of the Pawtuxet River model for similar exceedance probability flows. The North Branch Pawtuxet River is affected by the normal backwater from Pawtuxet River.

\section{Manning's Roughness Coefficients}

Manning's roughness coefficients (n) for the main channel and overbank areas of the North Branch Pawtuxet River were largely obtained from the existing FIS hydraulic model. Some adjustments to the "n" values were made from field observations and aerial photographs and by comparing the observed 2010 flood HWMs to the HEC-RAS model results. Manning's roughness coefficients range in value from 0.040 to 0.060 with a median of 0.051 for the main channel, and from 0.035 to 0.090 with a median of 0.070 for the overbank areas.

\section{Flow Lengths}

Main-channel and overbank-flow lengths were computed through the use of HEC-GeoRAS. Flow paths were defined by the NHD stream centerline and by the modeler for the overbanks. The main-channel length between cross sections ranged from 30 to 3,960 ft with a median length of $115 \mathrm{ft}$; lengths on the left and right banks were similar to the main channel. Short and long channel lengths typically are caused by meanders in the river.

\section{Hydraulic Structures}

Water levels in the North Branch Pawtuxet River can be affected by seven bridges and six dams (table 1-10). All structures were surveyed by the USGS in 2011. Table 1-10 lists the type of structures and the solution type used at bridges to compute the flood profile for the 1-percent AEP flow. Road overflow at the 1-percent AEP flow is noted. The solution type at bridges was determined by the model on the basis of the simulated conditions at the structure, which can vary according to the AEP flow.

\section{South Branch Pawtuxet River}

A HEC-RAS model was developed for a 9.1 mi reach of South Branch Pawtuxet River from its confluence with the North Branch Pawtuxet River to the Flat River Reservoir (fig. 1-3). The model was developed from cross-section and riverine-structure data surveyed in the field by the USGS, the effective FIS model, and 2011 LiDAR data. Peak discharges estimated for 10-, 2-, 1-, and 0.2-percent AEP floods were used with cross-sectional and riverine-structure information to compute the corresponding water-surface profiles.

Table 1-10. Summary of structures in the hydraulic model for the North Branch Pawtuxet River, Rhode Island.

[River station rounded to the nearest foot; AEP, annual exceedance probability; Inl Struct, in line structure; --, not applicable]

\begin{tabular}{cllcc}
\hline \multirow{2}{*}{$\begin{array}{c}\text { River station } \\
\text { (feet) }\end{array}$} & \multicolumn{1}{c}{ Description } & Structure type & \multicolumn{2}{c}{ 1-percent AEP flow } \\
\cline { 4 - 5 } & & Road overflow & Solution type \\
\hline 5,505 & Main Street, West Warwick & Bridge & No & Energy \\
7,750 & Breached Dam & Inl Struct & -- & Weir \\
8,630 & Phenix Dam & Inl Struct & -- & Weir \\
9,020 & Fairview Avenue, West Warwick & Bridge & No & Energy \\
10,505 & Lincoln Avenue, Coventry & Bridge & No & Energy \\
11,790 & Harris Pond Dam & Inl Struct & -- & Weir \\
13,700 & Abandoned bridge, Coventry & Bridge & No & Energy \\
14,530 & Arkwright Dam & Inl Struct & -- & Weir \\
14,895 & Hill Street, Cranston & Bridge & No & Energy \\
17,120 & Low head weir, Scituate & Inl Struct & -- & Weir \\
18,680 & Colvin Street, Scituate & Bridge & No & Energy \\
23,660 & Route 116 & Bridge & No & Energy \\
24,280 & Hope Dam & Inl Struct & -- & Weir \\
\hline
\end{tabular}

${ }^{1}$ Pressure and weir flow at the 0.2-percent AEP. 


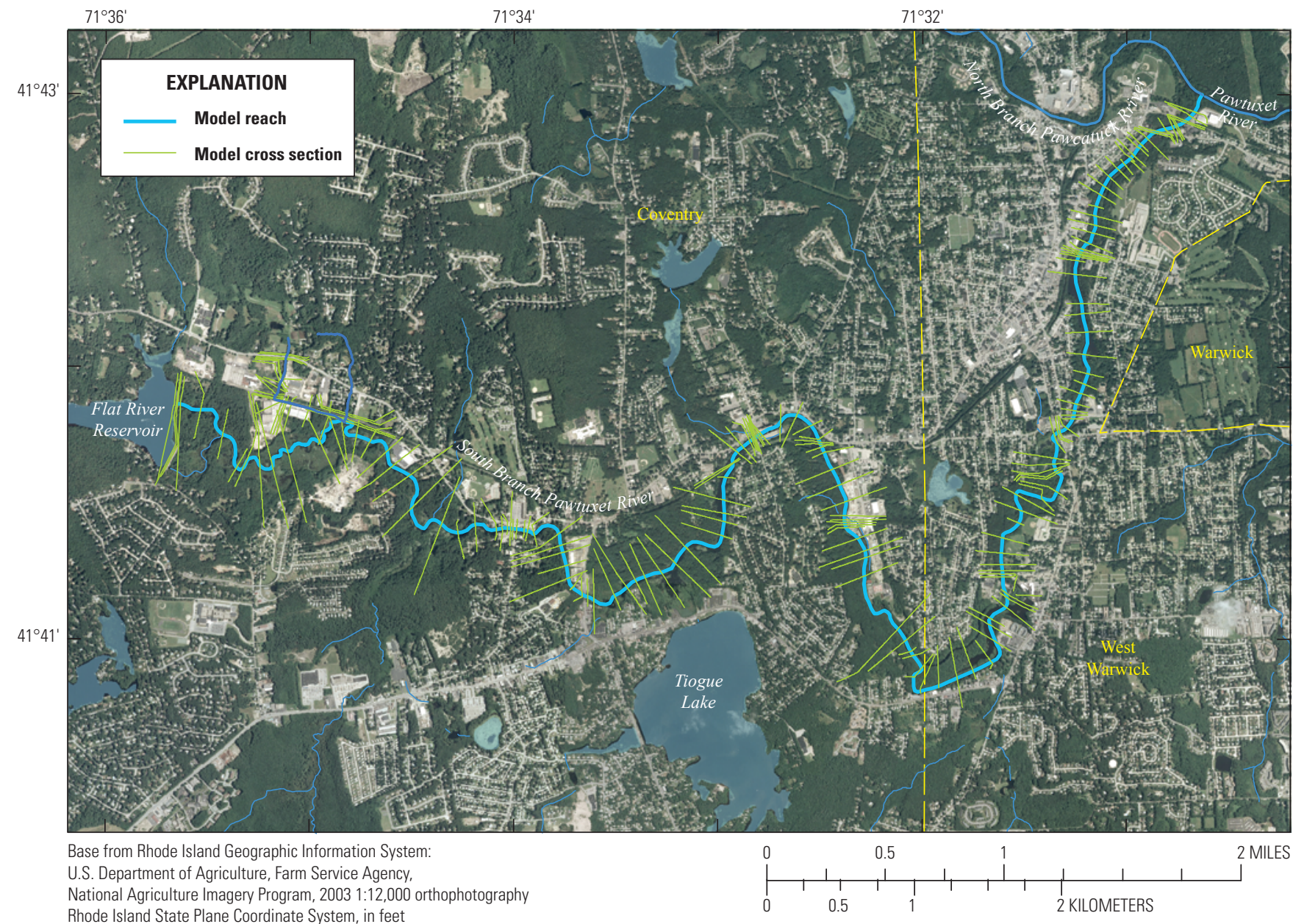

Figure 1-3. Hydraulic model reach for the South Branch Pawtuxet River, Rhode Island.

\section{Model Limit and Baseline Stationing}

The South Branch Pawtuxet River generally flows east, then northeast in east-central Rhode Island. The model starts at its confluence with the North Branch Pawtuxet River and ends in Flat River Reservoir near its outlet. Stationing for the model is referenced in feet from the confluence with the North Branch Pawtuxet River.

\section{Cross-Section and Structural-Geometry Data}

The South Branch Pawtuxet River HEC-RAS model consists of 166 cross sections, 11 bridges, and 11 dams (table 1-11). Field surveys were done at 22 riverine structures, 20 approaches, and 19 exits; other cross sections were obtained from the effective FIS. Elevations from LiDAR data were used to supplement or extend the cross sections as needed. All survey and model data are referenced to NAD 83 horizontal datum and NAVD 88 vertical datum.
No synthetic cross sections were generated for the model. However, sections at the upstream and downstream faces of structures were interpolated from the approach and exit cross sections, and the structure geometry. Obstructed and ineffective flow areas were specified as needed.

Table 1-11. Summary of cross sections in the hydraulic model for the South Branch Pawtuxet River, Rhode Island. [Available separately at http://pubs.usgs.gov/sir/2013/5192/
appendix/sir2013-5192_apend01.xls]

\section{Starting Water-Surface and Backwater Elevation}

The starting WSE at the confluence with the North Branch Pawtuxet River was determined from the computed WSE at the upstream end of the Pawtuxet River model for similar exceedance probability flows. The downstream part of the river is affected by the normal backwater from the Pawtuxet River. 


\section{Manning's Roughness Coefficients}

Manning's roughness coefficients (n) for the main channel and overbank areas of the South Branch Pawtuxet River were largely obtained from the existing FIS hydraulic model. Some adjustments to the " $\mathrm{n}$ " values were made from field observations and aerial photographs and by comparing the observed 2010 flood HWMs to the HEC-RAS model results. Manning's roughness coefficients range in value from 0.030 to 0.045 with a median of 0.035 for the main channel, and from 0.060 to 0.080 with a median of 0.080 for the overbank areas.

\section{Flow Lengths}

Main channel and overbank-flow lengths were computed through the use of HEC-GeoRAS. Flow paths were defined by the NHD stream centerline and by the modeler for the overbanks. The channel length between cross sections ranged from 21 to $1,611 \mathrm{ft}$ with a median $292 \mathrm{ft}$; lengths on the left and right banks were similar to the main channel. Short and long channel lengths typically are caused by meanders in the river.

\section{Hydraulic Structures}

Water levels in the South Branch Pawtuxet River can be affected by 11 bridges and 11 dams (table 1-12). Table 1-12 lists the type of structures and the solution type used at bridges to compute the flood profile for the 1-percent AEP flow. Road overflow at the 1-percent AEP flow is noted. The solution type at bridges was determined by the model on the basis of the simulated conditions at the structure, which can vary according to the AEP flow.

Table 1-12. Summary of structures in the hydraulic model for the South Branch Pawtuxet River, Rhode Island.

[River station rounded to the nearest foot; AEP, annual exceedance probability; Inl Struct, in line structure; --, not applicable]

\begin{tabular}{|c|c|c|c|c|}
\hline \multirow{2}{*}{$\begin{array}{l}\text { River station } \\
\text { (feet) }\end{array}$} & \multirow{2}{*}{ Description } & \multirow{2}{*}{ Structure type } & \multicolumn{2}{|c|}{ 1-percent AEP flow } \\
\hline & & & Road overflow & Solution type \\
\hline 800 & New York, New Haven, and Hartford Railroad & Bridge & No & Energy \\
\hline 960 & Bradford Soap Mill Dam & Inl Struct & -- & Weir \\
\hline 1,500 & Providence Street & Bridge & No & Energy \\
\hline 1,951 & Royal Mill footbridge & Bridge & $\mathrm{No}^{1}$ & Energy $^{2}$ \\
\hline 2,300 & Royal Mills Dam & Inl Struct & -- & Weir \\
\hline 4,770 & Factory Street & Bridge & No & Energy \\
\hline 4,890 & Artic Mill Dam & Inl Struct & -- & Weir \\
\hline 8,650 & Centerville Dam & Inl Struct & -- & Weir \\
\hline 9,113 & Main Street (West Warrick) & Bridge & No & Energy \\
\hline 13,669 & Pulaski Street & Bridge & No & Energy \\
\hline 14,465 & Pulaski Street dam & Inl Struct & -- & Weir \\
\hline 19,102 & New Dam (off New Dam Road) & Inl Struct & -- & Weir \\
\hline 22,810 & Sheltra Avenue dam & Inl Struct & -- & Weir \\
\hline 24,647 & Clarient Dam & Inl Struct & -- & Weir \\
\hline 24,793 & Bike path bridge below Laurel Avenue & Bridge & No & Energy \\
\hline 26,730 & Laurel Avenue & Bridge & No & Energy \\
\hline 26,759 & Laurel Avenue dam & Inl Struct & -- & Weir \\
\hline 27,514 & Washington Secondary Trail & Bridge & No & Energy \\
\hline 33,032 & Sandy Bottom Road & Bridge & No & Energy $^{2}$ \\
\hline 35,800 & Main Street (Washington) & Bridge & No & Energy \\
\hline 36,018 & Dam upstream of Main Street bridge & Inl Struct & -- & Weir \\
\hline 48,346 & Flat River Dam & Inl Struct & -- & Weir \\
\hline
\end{tabular}

${ }^{1}$ Road overflow indicated at the 0.2-percent AEP flow.

${ }^{2}$ Pressure and weir flow at 0.2-percent AEP. 


\section{Meshanticut Brook}

A HEC-RAS model was developed for a $4.6 \mathrm{mi}$ reach of Meshanticut Brook starting at the confluence with the Pawtuxet River (fig. 1-4). The model also includes Furnace Hill Brook as a separate reach, which is described later. The model was developed from cross sections and riverine structures surveyed in the field, cross sections obtained from the effective FIS, and 2011 LiDAR data. Peak discharges estimated for 10-, 2-, 1-, and 0.2-percent AEP floods were used with cross-sectional and riverine-structure information to compute the corresponding water-surface profiles.

\section{Model Limit and Baseline Stationing}

The Meshanticut Brook model starts at the confluence with the Pawtuxet River and ends at Phenix Avenue in Cranston. The model is divided into five reach segments, which include four main-channel segments and a bypass channel that was required to simulate a secondary channel through which flood waters pass from the west side to the east side of I-295 in by following the Wilbur Avenue underpass. The 2.3 mi segment upstream of Furnace Hill Brook is referred to as the Upper Reach. The $0.5 \mathrm{mi}$ segment below the Furnace Hill Brook to the bypass junction is referred to as the Lower Reach. The 0.3 main-channel segment below the bypass is referred to as Lower Reach 2, and the $0.3 \mathrm{mi}$ bypass channel is referred to as the Bypass. Below the confluence of the bypass with the main channel, the $1.5 \mathrm{mi}$ segment is referred to as Lower Reach 3. Meshanticut Brook stationing is in feet referenced from the confluence with the Pawtuxet River, and the bypass is referenced in feet upstream of its confluence with Meshanticut Brook.

\section{Cross-Section and Structural-Geometry Data}

The Meshanticut Brook model consists of 126 cross sections, 18 culverts, 3 bridges, and 2 dams (table 1-13). The bypass channel is defined by five cross sections. All the riverine structures were surveyed except for a small weir located between lanes of I-295, which was not accessible. The geometry for this weir was determined from the effective FIS model and LiDAR data. Field cross section surveys also were obtained at 16 approaches and 18 exits at riverine structures. Sixteen cross sections were obtained from the effective FIS model and modified outside of the channel using LiDAR data. LiDAR data were used to add 27 cross sections to reduce channel lengths or expansion-contraction ratios, or both. All survey and model data are referenced to NAD 83 horizontal datum and NAVD 88 vertical datum.

One cross section was synthesized by allowing HECRAS to interpolate between two adjacent sections that were $64 \mathrm{ft}$ apart. Sections at the upstream and downstream faces of structures were determined from the approach and exit cross sections and the structure geometry. Ineffective flow areas were specified in channel cross sections as needed.
Table 1-13. Summary of cross sections in the hydraulic model for Meshanticut Brook, Rhode Island.

[Available separately at http://pubs.usgs.gov/sir/2013/5192/ appendix/sir2013-5192_apend01.xls]

\section{Starting Water-Surface Elevation}

The starting WSE was specified as normal depth with a slope estimated to be $0.0081 \mathrm{ft} / \mathrm{ft}$, which is the channel slope between sections 918.6 and 539.6. The WSE in the downstream reach can be affected by backwater from the Pawtuxet River.

\section{Manning's Roughness Coefficients}

Manning's roughness coefficients (n) for the main channel and overbank areas of the Meshanticut Brook were obtained from the existing FIS hydraulic model then adjusted from field observations and aerial photographs. Manning's roughness coefficients (n) for the main channel and overbank areas of Meshanticut Brook were determined from field observation and aerial photographs. Estimates of Manning's roughness coefficients range from 0.032 to 0.075 with a median of 0.050 for the main channel, and from 0.040 to 0.130 with a median of about 0.065 for overbank areas.

\section{Flow Lengths}

Main-channel and overbank-flow lengths were computed through HEC Geo-RAS. Flow paths were defined by the NHD stream centerline and by the modeler for the overbanks. The main-channel length between cross sections ranged from 10 to $1,343 \mathrm{ft}$ with a median of $108 \mathrm{ft}$; lengths on the left and right banks were similar to the main channel. Short and long channel lengths typically are caused by meanders in the river.

\section{Hydraulic Structures}

Water levels in Meshanticut Brook can be affected by 3 bridges, 18 culverts, and 2 dams. All but one structure was surveyed in 2011 by the USGS. Table 1-14 lists the type of structures and the solution type used at bridges to compute the flood profile for the 1-percent AEP flow. Road overflow at the 1-percent AEP flow is noted. The solution type at bridges was determined by the model on the basis of the simulated conditions at the structure, which can vary according to the AEP flow.

\section{Furnace Hill Brook}

A HEC-RAS model was developed for a 2.6 mi reach of Furnace Hill Brook starting at the confluence of Meshanticut Brook (fig. 1-4). The model was developed from cross sections and riverine structures surveyed in the field, cross sections from the effective FIS, and LiDAR data. Peak discharges estimated from 10-, 2-, 1-, and 0.2-percent AEP floods were used with cross-sectional and riverine-structure information to compute the corresponding water-surface profiles. 


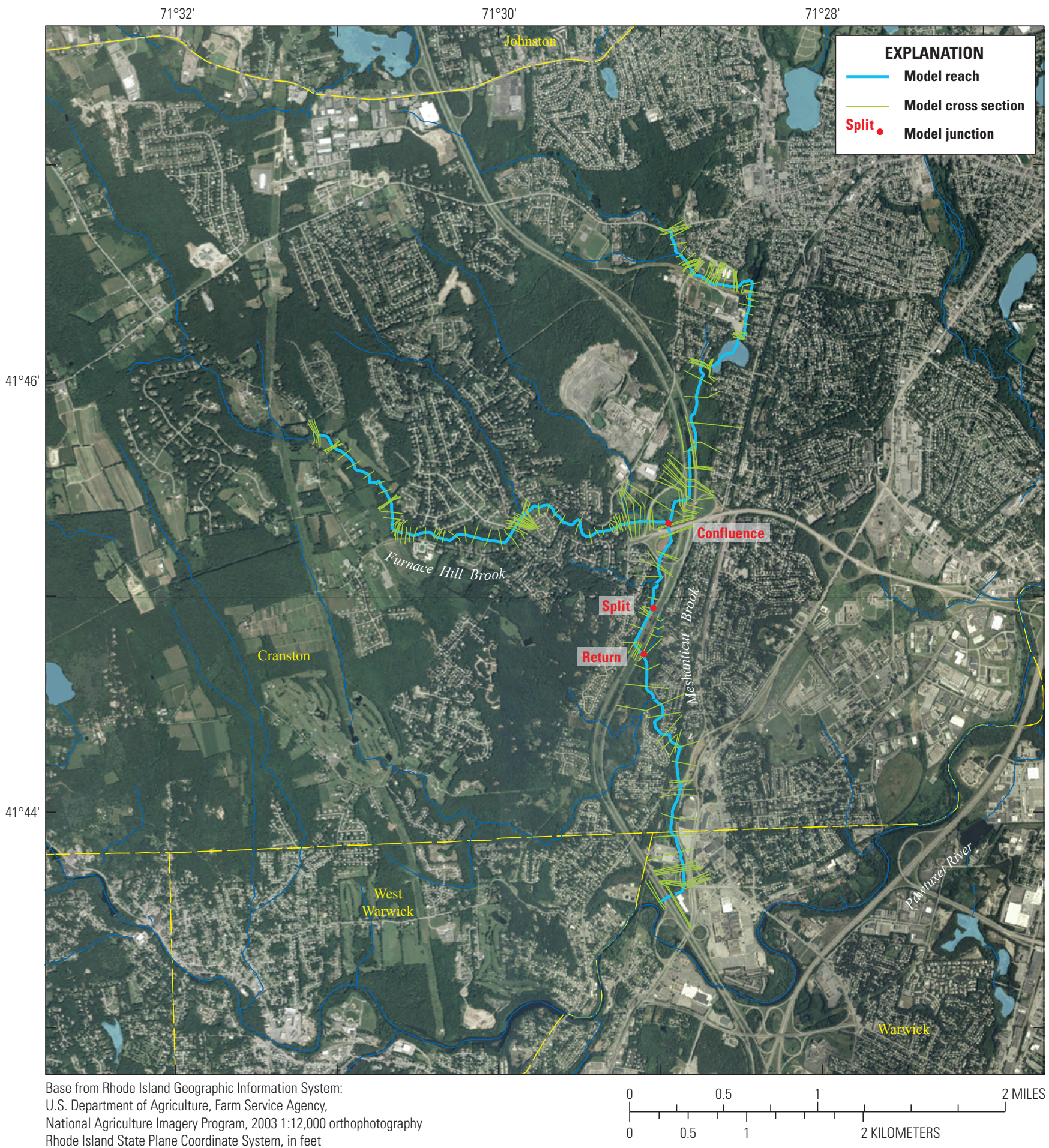

Figure 1-4. Hydraulic model reach for Meshanticut Brook and Furnace Hill Brook, Rhode Island. 
Table 1-14. Summary of structures in the hydraulic model for Meshanticut Brook, Rhode Island.

[River station rounded to the nearest foot; AEP, annual exceedance probability; --, not applicable; Inl Struct, in line structure]

\begin{tabular}{|c|c|c|c|c|}
\hline \multirow{2}{*}{$\begin{array}{l}\text { River station } \\
\text { (feet) }\end{array}$} & \multirow{2}{*}{ Description } & \multirow{2}{*}{ Structure type } & \multicolumn{2}{|c|}{ 1-percent AEP flow } \\
\hline & & & Road overflow & Solution type \\
\hline \multicolumn{5}{|c|}{ Lower Reach 3} \\
\hline 400 & Interstate 295 & Culvert & No & -- \\
\hline 1,011 & West Natick Road & Bridge & No & Energy \\
\hline 1,478 & Route 2 south off-ramp & Bridge & $\mathrm{No}^{1}$ & Energy \\
\hline 3,859 & New London Avenue & Culvert & No & -- \\
\hline 5,108 & Railroad bridge & Bridge & No & Energy \\
\hline \multicolumn{5}{|c|}{ Lower Reach 2} \\
\hline 8,201 & Interstate 295 north & Culvert & No & -- \\
\hline 8,469 & Interstate 295 north & Culvert & No & -- \\
\hline 9,544 & Wilbur Avenue & Culvert & Yes & -- \\
\hline \multicolumn{5}{|c|}{ Lower Reach } \\
\hline 11,160 & Interstate 295 south ramp & Culvert & $\mathrm{No}^{1}$ & -- \\
\hline 12,097 & Route 37 & Culvert & $\mathrm{No}^{1}$ & -- \\
\hline \multicolumn{5}{|c|}{ Upper Reach } \\
\hline 13,202 & Interstate 295 south & Culvert & Yes & -- \\
\hline 13,877 & Ralph's Pond weir & Inl Struct & -- & Weir \\
\hline 14,919 & Interstate 295 North & Culvert & $\mathrm{No}^{1}$ & -- \\
\hline 17,370 & Highland Street & Culvert & Yes & -- \\
\hline 17,559 & Lakeview Avenue & Culvert & Yes & -- \\
\hline 18,971 & Curtis Park Road & Culvert & Yes & -- \\
\hline 19,083 & Curtis Street & Culvert & Yes & -- \\
\hline 20,236 & Ambrose Street & Culvert & Yes & -- \\
\hline 21,219 & Ambrose Street & Culvert & Yes & -- \\
\hline 22,026 & School access road & Culvert & Yes & -- \\
\hline 22,576 & Phenix Avenue & Culvert & Yes & -- \\
\hline 22,724 & Phenix Avenue dam & Inl Struct & -- & Weir \\
\hline 24,096 & Scituate Avenue & Culvert & Yes & -- \\
\hline
\end{tabular}

${ }^{1}$ Road overflow indicated at the 0.2-percent AEP flow.

\section{Model Limit and Baseline Stationing}

The Furnace Hill Brook model starts at the confluence with Meshanticut Brook and ends at Pippen Orchard Road in Cranston. The model is incorporated into the Meshanticut HEC-RAS model and is identified by its name. The model stationing is referenced in feet upstream from its confluence with the Meshanticut Brook.

\section{Cross-Section and Structural-Geometry Data}

The Furnace Hill Brook HEC-RAS model consists of 79 cross sections, 6 bridges, 5 culverts, and 1 dam (table 1-15). Field surveys were made at 12 riverine structures, 11 approaches, and 12 exits; field surveys were extended with LiDAR data. LiDAR data were used to add 34 cross sections to reduce channel lengths or expansioncontraction ratios, or both. All survey and model data are referenced to NAD 83 horizontal datum and NAVD 88 vertical datum. Cross sections extracted from the effective FIS model were not directly used because the elevation data from that model generally did not reasonably match the new elevation information.

No synthetic cross sections were generated for the model. However, sections at the upstream and downstream faces of structures were copies of approach and exit cross sections adjusted for channel slope if required. The sections at the 
upstream and downstream faces of structures were interpolated from the overbank areas of the approach and exit cross sections, and the channel geometry at the structure. Ineffective flow areas were specified in channel cross sections as needed.

Table 1-15. Summary of cross sections in the hydraulic model for Furnace Hill Brook, Rhode Island.

\section{[Available separately at http://pubs.usgs.gov/sir/2013/5192/ appendix/sir2013-5192_apend01.xls]}

\section{Starting Water-Surface Elevation}

The starting WSEs were computed internally in HEC-RAS from the results of the Meshanticut Brook simulated WSEs at the confluence. Furnace Hill Brook is affected by normal backwater from Meshanticut Brook.

\section{Manning's Roughness Coefficients}

Manning's roughness coefficients (n) for the main channel and overbank areas of the Furnace Hill Brook were obtained from the existing FIS hydraulic model, then adjusted from field observations and aerial photographs. Estimates of Manning's roughness coefficients range from 0.040 to 0.075 with a median of 0.060 for the main channel, and from 0.035 to 0.100 with a median of 0.065 for the overbank areas.

\section{Flow Lengths}

Main-channel and overbank-flow lengths were computed through HEC-GeoRAS. Flow paths were defined by the NHD stream centerline and by the modeler for the overbanks. The main-channel length between cross sections ranged from 7 to $811 \mathrm{ft}$ with a median length of $106 \mathrm{ft}$; lengths on the left and right banks were similar to the main channel. Short and long channel lengths typically are caused by meanders in the river.

\section{Hydraulic Structures}

Water levels in Furnace Hill Brook can be affected by six bridges, five culverts, and one dam. All structures were surveyed in 2011 by the USGS. Table 1-16 lists the type of structures and the solution type used at bridges to compute the flood profile for the 1-percent AEP flow. Road overflow at the 1-percent AEP flow is noted. The solution types at bridges were determined by the model on the basis of the simulated conditions at the structure, which can vary according to the AEP flow.

\section{Flat River}

A HEC-RAS model was developed for a $2.8 \mathrm{mi}$ reach of Flat River starting at its mouth at Flat River Reservoir (fig. 1-5). The model was developed from cross sections and riverine structures surveyed in the field, cross sections from the effective FIS, and LiDAR data. Peak discharge estimated

Table 1-16. Summary of structures in the hydraulic model for Furnace Hill Brook, Rhode Island.

[River station rounded to the nearest foot; AEP, annual exceedance probability; --, not applicable; Inl Struct, in line structure]

\begin{tabular}{rllcc}
\hline \multirow{2}{*}{$\begin{array}{c}\text { River station } \\
\text { (feet) }\end{array}$} & \multicolumn{1}{c}{ Description } & Structure type & \multicolumn{2}{c}{ 1-percent AEP flow } \\
\cline { 4 - 5 } & & Road overflow & Solution type \\
\hline 613 & Route 37 ramps & Culvert & Yes & -- \\
1,208 & Natick Avenue & Culvert & No & -- \\
1,429 & Old Furnace Hill Road & Bridge & No & Momentum \\
5,213 & Phenix Avenue & Bridge & No & Energy \\
5,438 & Private bridge & Bridge & No & Momentum \\
5,522 & Kimberly Lane & Culvert & No & -- \\
5,613 & Abandoned culvert & Culvert & No & -- \\
9,121 & Abandoned dam & Inl Struct & -- & Weir \\
9,564 & Private bridge & Bridge & No & Energy ${ }^{2}$ \\
10,482 & Private bridge & Bridge & No & Energy \\
13,047 & Private bridge & Bridge & No & Energy \\
13,756 & Pippen Orchard Road & Culvert & Yes & -- \\
\hline
\end{tabular}

${ }^{1}$ Road overflow indicated at the 0.2-percent AEP flow.

${ }^{2}$ Changes to momentum at 0.2 -percent AEP. 


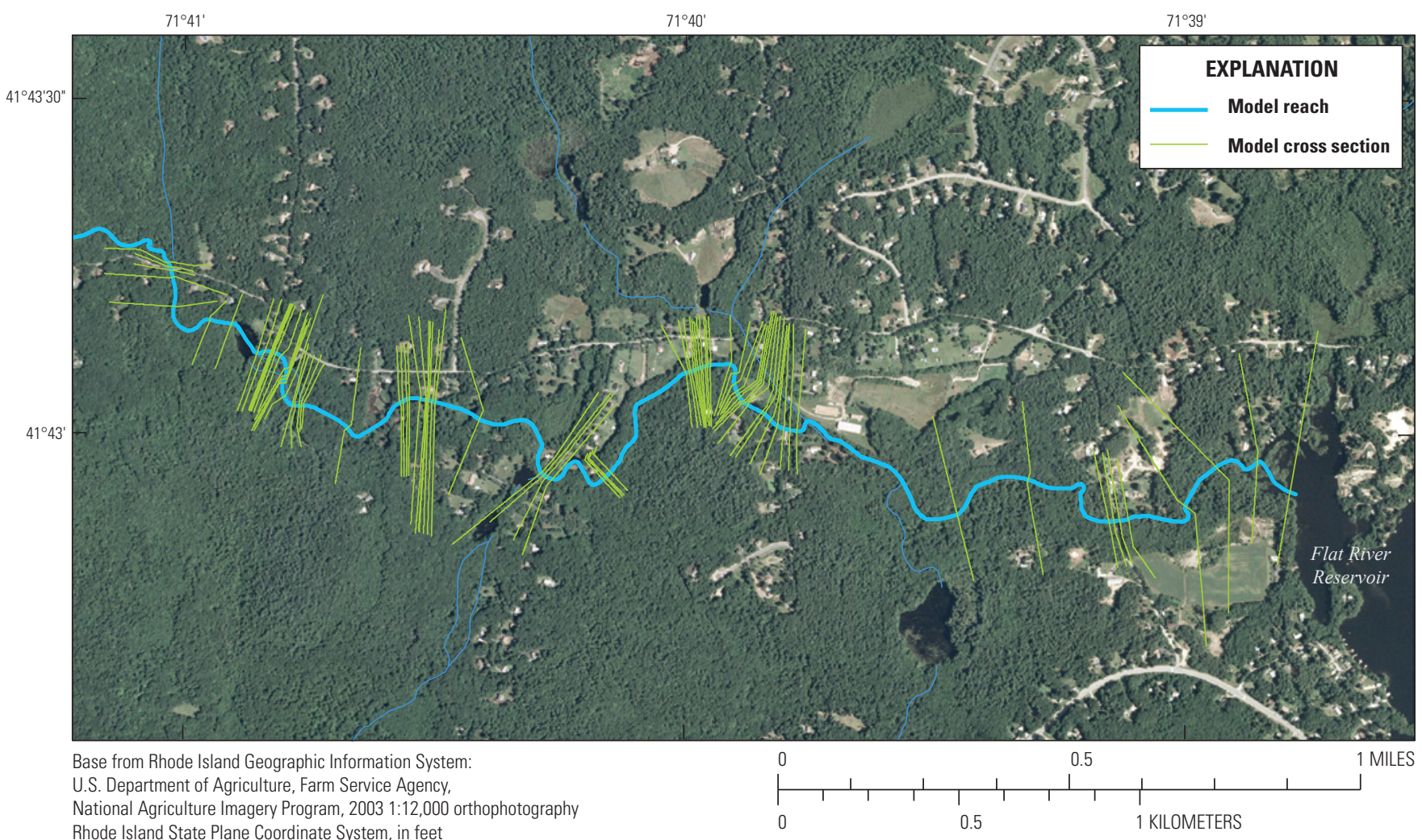

Figure 1-5. Hydraulic model reach for the Flat River, Rhode Island.

for 10-, 2-, 1-, and 0.2-percent AEP floods were used with cross-sectional and riverine-structure information to compute the corresponding water-surface profiles. In the effective FIS and in the updated HEC-RAS model, the reach is referred to as Flat River No. 1. During the time of the field surveys, plans had been approved to replace multiple barrel culverts at several road crossing (stations 6,100; 6,585; 9,450; and 14,630 ) with larger culverts that are less prone to debris jams. However, the updated model reflects conditions that existed at the time of the 2011 field surveys.

\section{Model Limit and Baseline Stationing}

The Flat River model starts at its mouth to Flat River Reservoir and ends just upstream of Maple Valley Road in Coventry. The model stationing is referenced in feet from the intersection of the stream centerline in Flat River Reservoir; the first cross section at the mouth is at $56.5 \mathrm{ft}$.

\section{Cross-Section and Structural-Geometry Data}

The Flat River model consists of 86 cross sections, 5 bridges, 6 culverts, and 3 dams (table 1-17). Field surveys were made at nine riverine structures, eight approaches, and nine exits; the approach and exit cross sections were extended with LiDAR data. Cross sections between structures were extracted from the effective FIS HEC-2 model and updated with LiDAR data beyond the channel. All survey and model data are referenced to NAD 83 horizontal datum and NAVD 88 vertical datum.

No synthetic cross sections were generated in the model. However, sections at the upstream and downstream faces of structures were copies of approach and exit cross sections adjusted for channel slope if required. The sections at the upstream and downstream faces of structures were interpolated from the approach and exit cross sections and the structure geometry. Ineffective flow areas were specified in channel cross sections as needed.

Table 1-17. Summary of cross sections in the hydraulic model for Flat River, Rhode Island. 


\section{Starting Water-Surface Elevation}

Flat River is affected by backwater conditions at Flat River Reservoir. The starting WSEs were obtained from the computed WSEs for similar exceedance probability flows from the upstream end of the South Branch Pawtuxet River model, which reflects the WSE in the Flat River Reservoir. The upstream cross section of the South Branch Pawtuxet River runs through the Flat River Reservoir near the outflow at the dam.

\section{Manning's Roughness Coefficients}

Manning's roughness coefficients ( $\mathrm{n}$ ) for the main channel and overbank areas of the Flat River were largely obtained from the existing FIS hydraulic model. Some adjustments to the " $n$ " values were made from field observations and aerial photographs. Manning's roughness coefficients range in value from 0.045 to 0.060 with a median of 0.055 for the main channel and 0.090 to 0.135 with a median of 0.120 for the overbank areas.

\section{Flow Lengths}

Main-channel and overbank-flow lengths were computed through HEC-GeoRAS. Flow paths were defined by the NHD stream centerline and by the modeler for the overbanks. The main-channel length between cross sections ranged from 3 to $1,905 \mathrm{ft}$ with a median length of $48 \mathrm{ft}$; lengths on the left and right banks were similar to the main channel. Short and long channel lengths typically are caused by meanders in the river.

\section{Hydraulic Structures}

Water levels in Flat River can be affected by five bridges, six culverts, and three dams. All structures were surveyed in 2011 by the USGS. Table 1-18 lists the type of structures and the solution type used at bridges to compute the flood profile for the 1-percent AEP flow. Road overflow at the 1-percent AEP flow is noted. The solution type at bridges was determined by the model on the basis of the simulated conditions at the structure, which can vary according to the AEP flow.

\section{Quidneck Brook}

A HEC-RAS model was developed for a $0.67 \mathrm{mi}$ reach of Quidneck Brook starting at its mouth at Flat River Reservoir (fig. 1-6). The model was developed from cross sections and riverine structures surveyed in the field, cross sections from the effective FIS, and LiDAR data. Peak discharges estimated for 10-, 2-, 1-, and 0.2-percent AEP floods were used with cross-sectional and riverine-structure information to compute the corresponding water-surface profiles.

\section{Model Limit and Baseline Stationing}

The Quidneck Brook model starts at its mouth at Flat River Reservoir and ends at the outflow of Stump Pond. The model stationing is referenced in feet from the intersection of the stream centerline in Flat River Reservoir; the first cross section at the mouth is at $1,152 \mathrm{ft}$.

Table 1-18. Summary of structures in the hydraulic model for Flat River, Rhode Island.

[River station rounded to the nearest foot; AEP, annual exceedance probability; --, not applicable; Inl Struct, in line structure]

\begin{tabular}{|c|c|c|c|c|}
\hline \multirow{2}{*}{$\begin{array}{l}\text { River station } \\
\text { (feet) }\end{array}$} & \multirow{2}{*}{ Description } & \multirow{2}{*}{ Structure type } & \multicolumn{2}{|c|}{ 1-percent AEP flow } \\
\hline & & & Road overflow & Solution type \\
\hline 2,170 & Maple Valley Road & Culvert & No & -- \\
\hline 6,100 & Hammet Road & Culvert & Yes & -- \\
\hline 6,360 & Private dam upstream of Hammet Road & Inl Struct & -- & Weir \\
\hline 6,585 & Private road to field & Culvert & Yes & -- \\
\hline 7,190 & Private bridge & Bridge & Yes & Energy and weir \\
\hline 7,350 & Private bridge & Bridge & Yes & Pressure and weir \\
\hline 8,680 & Footbridge downstream of Franklin Road & Bridge & No & Energy \\
\hline 9,450 & Franklin Road & Culvert & Yes & -- \\
\hline 10,990 & Private bridge at 911 Maple Valley Road & Bridge & No & Energy \\
\hline 11,010 & Private dam at 911 Maple Valley Road & Inl Struct & -- & Weir \\
\hline 11,200 & Private drive at 935 Maple Valley Road & Culvert & Yes & -- \\
\hline 12,400 & Private drive at 1001 Maple Valley Road & Bridge & Yes & Pressure and weir \\
\hline 13,183 & Onley-Mathewson Dam & Inl Struct & -- & Weir \\
\hline 14,630 & Maple Valley Road upstream & Culvert & Yes & -- \\
\hline
\end{tabular}


$71^{\circ} 38^{\prime} 30^{\prime \prime}$

$71^{\circ} 38^{\prime}$

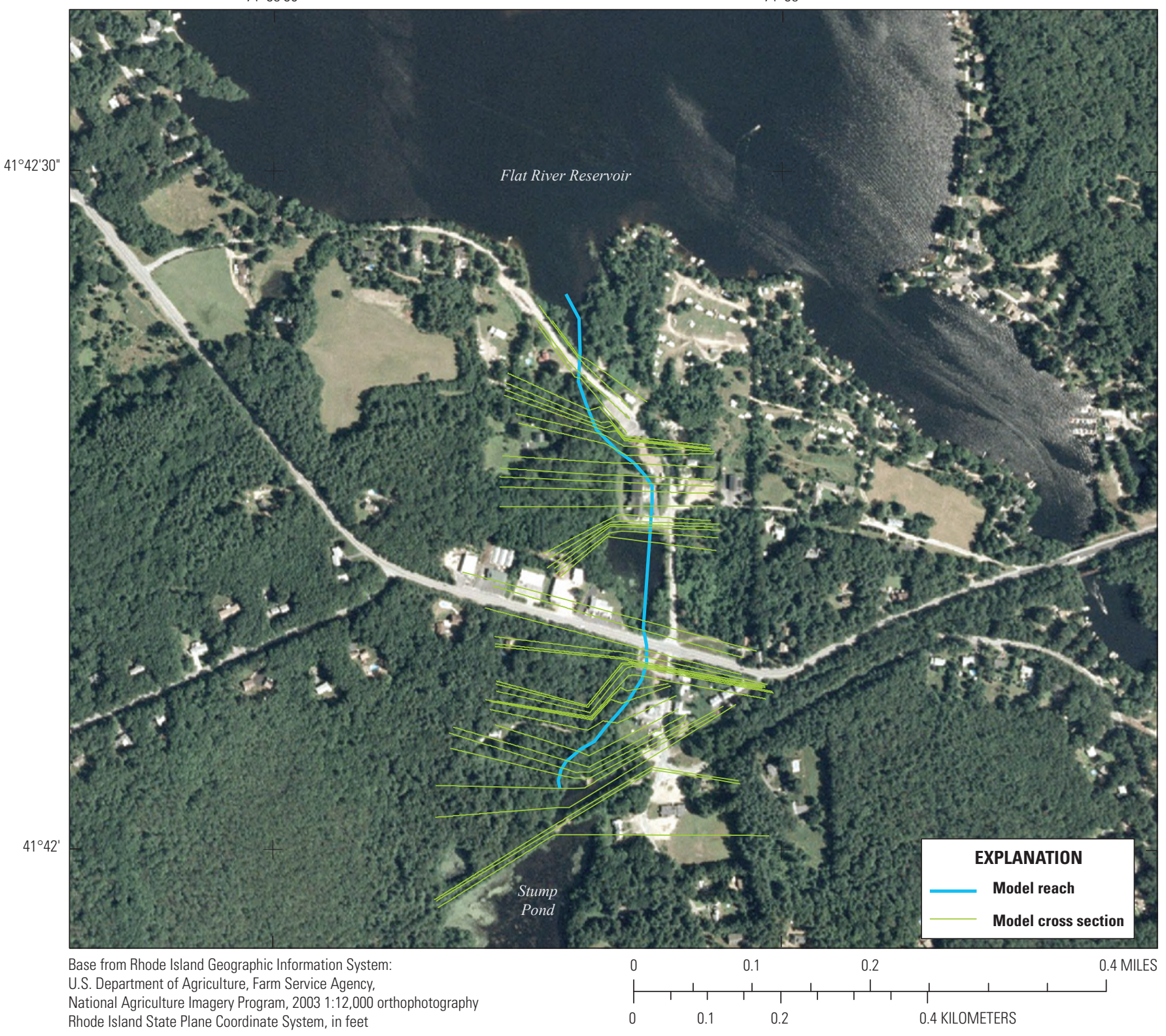

Figure 1-6. Hydraulic model reach for Quidneck Brook, Rhode Island. 


\section{Cross-Section and Structural-Geometry Data}

The Quidneck Brook model consists of 43 cross sections, 3 bridges, 2 culverts, and 2 dams (table 1-19). Field surveys were made at five riverine structures, five approaches, and five exits, which were extended with LiDAR data. Cross sections between structures were extracted from the effective FIS model and updated with LiDAR data beyond the channel. All survey and model data are referenced to NAD 83 horizontal datum and NAVD 88 vertical datum.

No synthetic cross sections were generated for the model. However, sections at the upstream and downstream faces of structures were copies of approach and exit cross sections adjusted for channel slope if required. The sections at the upstream and downstream faces of structures were interpolated from the approach and exit cross sections, and the structure geometry. Ineffective flow areas were specified in channel cross sections as needed.

Table 1-19. Summary of cross sections in the hydraulic model for Quidneck Brook, Rhode Island.

[Available separately at http://pubs.usgs.gov/sir/2013/5192/ appendix/sir2013-5192_apend01.xls]

\section{Starting Water-Surface Elevation}

The starting WSEs were obtained from the computed WSEs from the upstream end of the South Branch Pawtuxet River model (Flat River Reservoir) for similar exceedance probability flows. Quidneck Brook is affected by backwater from Flat River Reservoir.

\section{Manning's Roughness Coefficients}

Manning's roughness coefficients (n) for the main channel and overbank areas of the Quidneck Brook were largely obtained from the existing FIS hydraulic model. Some adjustments to the "n" values were made from field observations and aerial photographs. Manning's roughness coefficients range in value from 0.045 to 0.060 with a median of 0.055 for the main channel and 0.105 to 0.130 with a median of 0.120 for the overbank areas.

\section{Flow Lengths}

Main-channel and overbank flow lengths were computed through HEC-GeoRAS. Flow paths were defined by the NHD stream centerline and by the modeler for the overbanks. The main-channel length between cross sections ranged from 7 to $385 \mathrm{ft}$ with a median length of $43 \mathrm{ft}$; lengths on the left and right banks were similar to the main channel. Short and long channel lengths typically are caused by meanders in the river.

\section{Hydraulic Structures}

Water levels in Quidneck Brook can be affected by three bridges, two culverts, and two dams. All structures were surveyed in 2011 by the USGS. Table 1-20 lists the type of structures and the solution type used at bridges to compute the flood profile for the 1-percent AEP flow. Road overflow at the 1-percent AEP flow is noted. The solution type at bridges was determined by the model on the basis of the simulated conditions at the structure, which can vary according to the AEP flow.

\section{South Branch Pawtuxet River Tributary A1}

A HEC-RAS model was developed for a $0.52 \mathrm{mi}$ reach of an unnamed tributary to the South Branch Pawtuxet River referred to as Tributary A1 (fig. 1-7). The model was developed from cross sections and riverine structures surveyed in the field, cross sections from the effective FIS, and LiDAR data. Peak discharge estimated from 10-, 2-, 1-, and 0.2-percent AEP floods were used with cross-sectional and riverine-structure information to compute the corresponding water-surface profiles. In the model, the reach is referred to as TribA1. The culvert at station 1,450 , which can cause backwater, is scheduled to be replaced, but the model reflects conditions that existed at the time of the 2011 field survey.

Table 1-20. Summary of structures in the hydraulic model for Quidneck Brook, Rhode Island.

[River station rounded to the nearest foot; AEP, annual exceedance probability; Inl Struct, in line structure; --, not applicable]

\begin{tabular}{cllcc}
\hline \multirow{2}{*}{$\begin{array}{c}\text { River station } \\
\text { (feet) }\end{array}$} & \multicolumn{1}{c}{ Description } & Structure type & \multicolumn{2}{c}{ 1-percent AEP flow } \\
\cline { 4 - 5 } & & Road overflow & Solution type \\
\hline 1,205 & Old Flat River Road & Bridge & No & Energy \\
1,965 & Coventry Center Pond & Inl Struct & -- & Weir \\
2,500 & Flat River Road (Route 117) & Culvert & No & -- \\
2,605 & Private bridge & Bridge & Yes & Energy \\
2,635 & Private drive & Culvert & Yes & -- \\
3,215 & Coventry Reservoir Dam & Inl Struct & -- & Weir \\
3,420 & Abandoned railroad bridge & Bridge & No & Energy \\
\hline
\end{tabular}




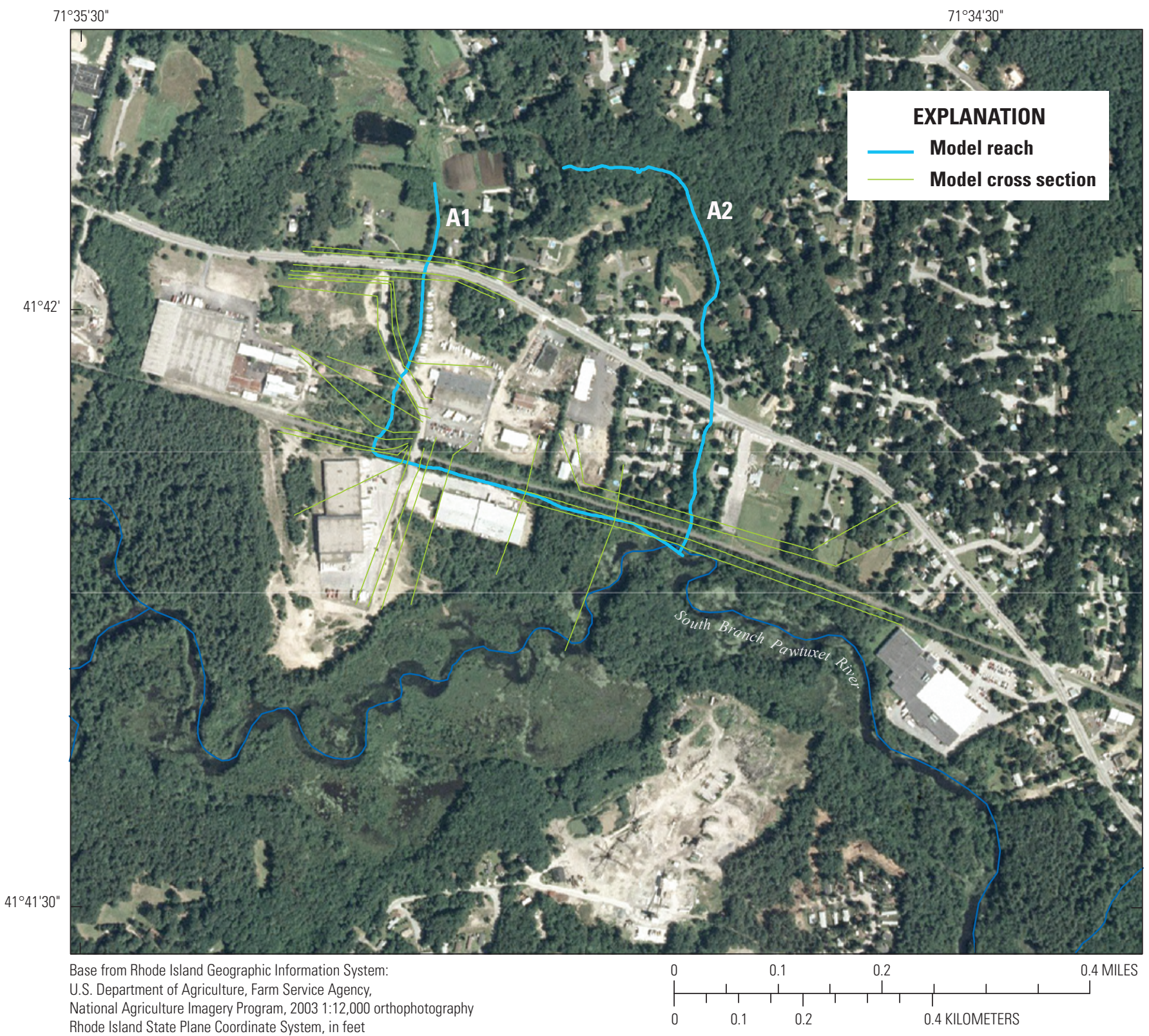

Figure 1-7. Hydraulic model reaches for South Branch Pawtuxet River Tributaries A1 and A2, Rhode Island. 


\section{Model Limit and Baseline Stationing}

Tributary A1 model starts at its confluence with the South Branch Pawtuxet River and ends just above Flat River Road (Route 117). The model stationing is referenced in feet from its confluence with the South Branch Pawtuxet River.

\section{Cross-Section and Structural-Geometry Data}

The Tributary A1 model consists of 20 cross sections and 4 culverts (table 1-21). Field surveys were made at the culverts and their approach and exit cross sections. Cross sections between structures were extracted from the effective FIS model and updated with LiDAR data beyond the channel bed. All survey and model data are referenced to NAD 83 horizontal datum and NAVD 88 vertical datum. No synthetic cross sections were generated for the model. Ineffective flow areas are specified in channel cross sections as needed.

Table 1-21. Summary of cross sections in the hydraulic model for the South Branch Pawtuxet River Tributaries A1 and A2, Rhode Island.

[Available separately at http://pubs.usgs.gov/sir/2013/5192/ appendix/sir2013-5192_apend01.xls]

\section{Starting Water-Surface Elevation}

The starting WSEs were obtained from the computed WSEs of the South Branch Pawtuxet River model at station 42,112. Tributary A1 is affected by backwater near its confluence with the South Branch Pawtuxet River.

\section{Manning's Roughness Coefficients}

Manning's roughness coefficients (n) for the main channel and overbank areas of the Tributary A1 were largely obtained from the existing FIS hydraulic model. Some adjustments to the " $n$ " values were made from field observations and aerial photographs. Manning's roughness coefficient value was a consistent 0.040 for the main channel and ranged from 0.065 to 0.070 with a median of 0.067 for the overbank areas.

\section{Flow Lengths}

Main-channel and overbank-flow lengths were computed through HEC-GeoRAS. Flow paths were defined by the modeler for the channel and the overbanks. It should be noted that a stream centerline in the NHD does not exist for Tributary A1. The main-channel length between cross sections ranged from 16 to $477 \mathrm{ft}$ with a median length of $58 \mathrm{ft}$; lengths on the left and right banks were similar to the main channel.

\section{Hydraulic Structures}

Water levels in Tributary A1 can be affected by four culverts. All structures were surveyed in 2011 by the USGS. The structure type and the presence of road overflow, at the 1-percent AEP flow for Tributary A1 are listed in table 1-22.

\section{South Branch Pawtuxet River Tributary A2}

A HEC-RAS model was developed for a 0.04 mi reach of an unnamed tributary to the South Branch Pawtuxet River and is referred to as Tributary A2 (fig. 1-7). The model was developed from cross sections and riverine structure surveyed in the field, cross sections from the effective FIS, and LiDAR data. Peak discharges estimated from 10-, 2-, 1-, and 0.2-percent AEP floods were used with cross-sectional and riverine-structure information to compute the corresponding water-surface profiles. In the updated model, the reach is referred to as TribA2.

\section{Model Limit and Baseline Stationing}

Tributary A2 starts at the confluence with the South Branch Pawtuxet River and ends at the approach to a culvert under the Washington Trail path (old railroad). It should be noted that Tributary A1 and A2 drain into the South Branch Pawtuxet River at the same location. The model stationing is referenced in feet from its confluence with the South Branch Pawtuxet River.

Table 1-22. Summary of structures in the hydraulic model for the South Branch Pawtuxet River Tributary A1, Rhode Island.

[River station rounded to the nearest foot; AEP, annual exceedance probability; --, not applicable]

\begin{tabular}{clccc}
\hline \multirow{2}{*}{$\begin{array}{c}\text { River station } \\
\text { (feet) }\end{array}$} & \multicolumn{1}{c}{ Description } & Structure type & \multicolumn{2}{c}{ 1-percent AEP flow } \\
\cline { 4 - 5 } & & Road overflow & Solution type \\
\hline 1,450 & Industrial Drive below Washington Trail & Culvert & Yes & -- \\
1,700 & Washington Trail path (old railroad) & Culvert & No & -- \\
2,100 & Industrial Drive upstream of Washington Trail & Culvert & Yes & -- \\
2,700 & Flat River Road (Route 117) & Culvert & Yes & -- \\
\hline
\end{tabular}




\section{Cross-Section and Structural-Geometry Data}

The Tributary A2 HEC-RAS model consists of four cross sections and one culvert (table 1-21). Field surveys were made at the culvert and at its approach and exit. All survey and model data are referenced to NAD 83 horizontal datum and NAVD 88 vertical datum. No synthetic cross sections were generated for the model. Ineffective flow areas are specified in channel cross sections as needed.

\section{Starting Water-Surface Elevation}

The starting WSEs were obtained from the computed WSEs for the South Branch Pawtuxet River model at station 42,112 . Tributary A2 is affected by backwater near its confluence with the South Branch Pawtuxet River.

\section{Manning's Roughness Coefficients}

Manning's roughness coefficients ( $\mathrm{n}$ ) for the main channel and overbank areas of the Tributary A2 were largely obtained from the existing FIS hydraulic model. Some adjustments to the " $n$ " values were made from field observations and aerial photographs. Manning's roughness coefficients range in value from 0.040 to 0.047 with a median of 0.045 for the main channel, and were a consistent 0.080 for the overbank areas.

\section{Flow Lengths}

Main-channel and overbank-flow lengths were computed through HEC-GeoRAS. Flow paths were defined by the modeler for the channel and the overbanks. It should be noted that no stream centerline exists in the NHD for Tributary A2. The main-channel length between cross sections ranged from 38 to $83 \mathrm{ft}$ with a median length of $45 \mathrm{ft}$; lengths on the left and right banks were similar to the main channel.

\section{Hydraulic Structures}

Water levels in Tributary A2 can be affected by one culvert (station 100). The structure was surveyed in 2011 by the USGS. The simulated water surface at the 1-percent AEP flow was above the top of the culvert but below the road.

\section{Field Survey Quality Control}

At most structures that affect river conveyance, such as bridges, culverts, and dams, the USGS conducted field surveys following FEMA guidelines and standards for data acquisition for flood mapping (FEMA, 2011). The USGS conducted both global positioning system (GPS) and conventional surveys for this study. The GPS surveys were conducted to establish a control point at each section using Trimble R8 receivers, which support the L1, L2, and GLONASS L2C and L5 signals. Conventional surveys were conducted to obtain stream and hydraulic-structure geometry using the control points for vertical and horizontal reference. The horizontal position is the NAD 83 using Rhode Island State Plane coordinates. The vertical elevation is the NAVD 88. Third order accuracy (horizontal and vertical) was maintained for all conventional survey data collected. Control for the USGS survey was established using National Geodetic Survey (NGS) monuments (benchmarks) with known horizontal or vertical coordinates, or both (table 1-23).

Continuous real-time differential corrections to the field GPS horizontal and vertical positions were made using a proprietary fixed-base station GPS network operated by KeyNetGPS, Inc. The network and associated software determines corrections for satellite signals received by the field GPS receiver for ionosphere and other atmospheric disturbances recorded at three or more of the closest fixedbase stations relative to the position of the field GPS receiver. The fixed-base station receivers continuously stream data to a central server, which calculates corrections in real time at the location of the field GPS receiver. The fixedstation network in the Rhode Island region consists of five base stations-Providence, R.I. (NBC1); Fall River, Mass. (ABL1); Framingham, Mass. (KP16); Boston, Mass. (KP19); and Norwich, Conn. (MTG1). Quality-assurance GPS measurements were made at $36 \mathrm{NGS}$ benchmarks (BMs) with vertical datum throughout the study area. The elevation of the GPS measured benchmarks yielded a vertical root mean square error (RMSE) of 0.10 and $0.14 \mathrm{ft}$ for the two GPS units used for field surveys. 
Table 1-23. Comparison of U.S. Geological Survey measured coordinates and elevations to established National Geodetic Survey (NGS) benchmarks used for quality control of hydraulic model field surveys in Rhode Island.

[BM, benchmark; W, west; PID, permanent identifier; NGS, National Geodetic Survey; NAVD 88, North American Vertical Datum of 1988; NAD 83, North American Datum of 1983; WGS, World Geodetic System - minor differences with NAD 83 because of different reference ellipsoids. NAD 83 is stationary in time while WGS can shift in time but the WGS 84 and NAD 83 are intended to match; Delta, difference between established reference and surveyed coordinates or elevation; GPS, global positioning system; RMSE, root mean square error]

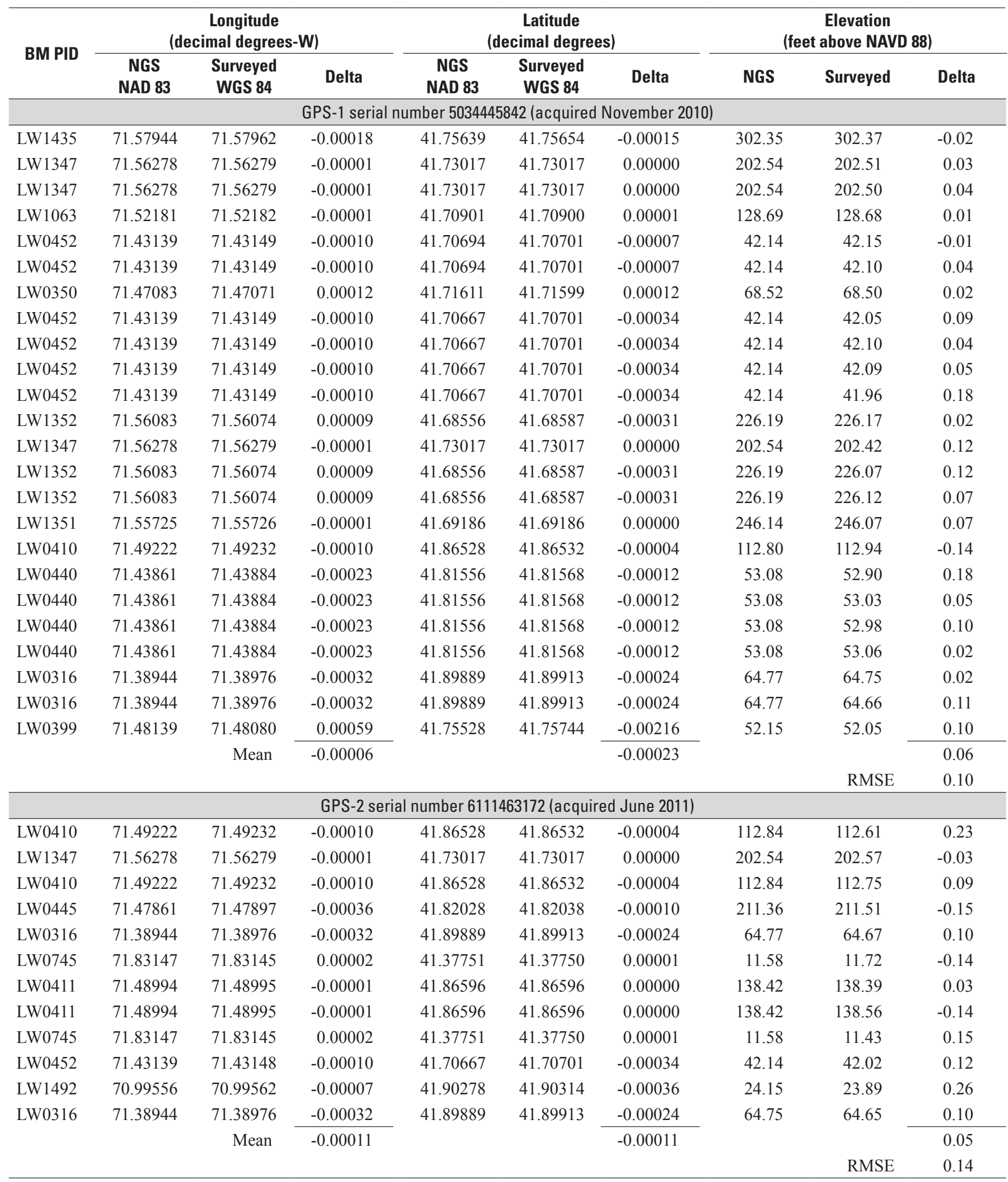




\section{References}

Ackerman, C.T., 2011, HEC-GeoRAS GIS tools for support of HEC-RAS using ArcGIS-user's manual (version 4.3.93): Davis, Calif., U.S. Army Corps of Engineers, Hydrologic Engineering Center, CPD-83, 244 p.

Brunner, G.W., 2010a, HEC-RAS river analysis system, user's manual (version 4.1): Davis, Calif., U.S. Army Corps of Engineers, Hydrologic Engineering Center, CPD-68, 766 p.

Brunner, G.W., 2010b, HEC-RAS river analysis system, hydraulic reference manual (version 4.1): Davis, Calif., U.S. Army Corps of Engineers, Hydrologic Engineering Center, CPD-69, 411 p.

EA Engineering, Science, and Technology, Inc., 2010, Pawtuxet River restoration project-Pawtuxet River, Cranston and Warwick, Rhode Island-Application to alter: Warwick, R.I., EA project no. 62277.01, 70 p.

FEMA - Federal Emergency Management Agency

FEMA, 2009, Flood Insurance Study-Providence County, Rhode Island: community no. 44007CV001A, 3 v., 262 p.

FEMA, 2010, Flood Insurance Study-Kent County, Rhode Island: community no. 44003CV001A, 132 p.

FEMA, 2011, Guidelines and standards for flood hazard mapping partners, Appendix M: Data capture standards: $170 \mathrm{p}$.

Federal Highway Administration, 1990, User's manual for WSPRO-A computer model for water surface profile computations: Publication no. FHWA-IP-89-027, 177 p.

Flynn, K.M., Kirby, W.H., and Hummel, P.R., 2006, Users manual for PeakFQ, annual flood-frequency analysis using Bulletin 17B guidelines: U.S. Geological Survey Techniques and Methods Report 4-B4, 42 p.
Kleinschmidt Energy and Water Resource Consultants, 2005, Pawtuxet River anadromous fish passage restoration project feasibility study: Essex, Conn., Kleinschmidt, 96 p.

Milone \& MacBroom, Inc., 2008, Pawtuxet River restoration alternatives assessment: Cheshire, Conn., MMI \#3020-01-2, $36 \mathrm{p}$.

MOD, 2008, Updating tidal profiles for New England coastline: Report to Federal Emergency Management Agency, $41 \mathrm{p}$.

SAS Institute, Inc., 1990, SAS/Stat user's guide, version 6 (4th ed.): Cary, N.C., v. 1 and 2, 1, 686 p.

U.S. Army Corps of Engineers, 1988, Tidal flood profiles New England coastline: Hydraulics and Water Quality Section, New England Division, 29 p.

U.S. Interagency Advisory Committee on Water Data, 1982, Guidelines for determining flood flow frequency: Reston, Va., U.S. Geological Survey, Office of Water Data Coordination, Bulletin 17B of the Hydrology Subcommittee, $183 \mathrm{p}$.

Warner, J.C., Brunner, G.W., Wolfe, B.C., and Piper, S.S, 2010, HEC-RAS river analysis system, applications guide (version 4.1): Davis, Calif., U.S. Army Corps of Engineers, Hydrologic Engineering Center, CPD-70, 351 p.

Zarriello, P.J., Ahearn, E.A., and Levin, S.B., 2012, Magnitude of flood flows for selected annual exceedance probabilities in Rhode Island, through 2010: U.S. Geological Survey Scientific Investigations Report 2012-5109, 93 p. (available at http://pubs.usgs.gov/sir/2012/5109/.) 
THIS PAGE INTENTIONALLY LEFT BLANK 


\section{Appendix 2. Review of the Hydraulic Model for the Pocasset River Basin}




\section{Introduction}

The hydraulic model for the Pocasset River Basin includes 11.8 miles (mi) of the Pocasset River and two tributaries-Dry Brook (3.0 mi) and Simmons Brook (3.6 mi). The hydraulic model was obtained from the Natural Resources Conservation Service (NRCS) (Kevin Farmer, NRCS, written commun., 2011), which was developed in 2006 to evaluate different build-out and flood-control strategies in the basin (Bachand and others, 2007). A number of project files were built to evaluate alternatives, but for this study, the geometry file "Base GIS Geometry but Fixed Mill St Br" was used as it reflects current (2010) conditions.

The NRCS hydraulic model was developed using Hydrologic Engineering Center-River Analysis System (HEC-RAS) version 3.1 .1 by initially modifying models that were developed for flood insurance study (FIS) for the City of Cranston (community no. 445396) and the FIS for the Town of Johnston (community no. 440018). Input files from previous FIS hydraulic models-HEC-2 and Water Surface Profile (WSP-2) - were used and augmented with field surveys made during January-April 2001 mostly at bridges and culverts. The existing FIS models were not calibrated to known or observed high-water marks (HWMs).

A digital terrain model (DTM) of the watershed with a 2-foot (ft) contour interval was developed by the NRCS during 2001 and 2002. The DTM data, along with field survey data, were used to construct new geometry data for the hydraulic model. The model was calibrated to the March 21-22, 2001, storm using a limited number of HWMs determined from photographs and TR-20 simulated flows from recorded precipitation at Providence (National Oceanic and Atmospheric Administration (NOAA) WBAN-14765). It was not known whether the HWMs reflect the peak water level or whether the water level was affected by obstructions in the channel, but debris was observed downstream of one HWM. A storm on October 15-16, 2005, characterized as a 1-percent annual exceedance probability (AEP) event, was later used to evaluate the revised model by the NRCS. The HWMs obtained from that event indicated that the model-simulated watersurface elevation (WSE) was as much as $6 \mathrm{ft}$ higher than the observed WSE (Schmidt and others, 2007).

In this study, flows reported in the effective FIS, included in the NRCS revised model, and revised flows from recent analysis by Zarriello and others (2012) were run in the HEC-RAS (ver. 4.1.1) model representing the current (2010) conditions. No other changes were made to the NRCS model other than the changes to the flows. The HEC-RAS model was run in steady-state mode, although the model also was built to run unsteady-flow simulations.

\section{Scope of Work}

The hydraulic model for the Pocasset River Basin includes Pocasset River and its two main tributaries-Dry Brook and Simmons Brook. The model is contained within Providence County, Rhode Island.

The Pocasset River model starts at its confluence with the Pawtuxet River in the City of Cranston and ends about $11.8 \mathrm{mi}$ upstream near the center of the Town of Johnston (fig. 1). The Pocasset River portion of the model is divided into two river segments - one that defines the main channel with five reach segments to define junctions of Dry Brook, Simmons Brook, and a split channel flow (fig. 2-1; table 2-1). The second river segment defines the secondary channel where it splits just upstream of St. Ann's Cemetery and then rejoins the main channel about $0.5 \mathrm{mi}$ downstream in the main channel. The secondary channel is defined in the model as "Pocas Riv Split." The river generally runs in a south-southeast direction.

Separate river segments define Dry Brook and Simmons Brook. Dry Brook starts at its confluence with the Pocasset River and ends about 3.0 mi upstream about midway between Jillison Reservoir and Oak Swamp Reservoir. Simmons Brook starts at its confluence with the Pocasset River and ends about 3.6 mi upstream at Simmons Upper Reservoir.

\section{Engineering Analyses}

The engineering analyses include hydrologic and hydraulic analyses. The engineering analysis in this study was limited to the hydrologic analysis of flood magnitudes for various locations in the hydraulic model. The hydraulic model was developed by the NRCS, as previously mentioned, and is documented in Bachand and others (2007) and Schmidt and others (2007).

\section{Hydrologic Analysis}

The effective FIS flows for 10-, 2-, 1-, and 0.2-percent AEP floods were computed with the TR-20 rainfall-runoff model from synthetic 24-hour precipitation corresponding to the same AEPs. The synthetic total precipitation was obtained from NOAA TP-40 and simulated using NRCS (formerly Soil Conservation Service (SCS)) type-III rainfall distribution. The FIS report states the FIS flow values were generated using the SCS curve number and "investigated for flow rate reduction based on existing reports, studies, and gaged data." However, no other information on the flow-rate reductions was provided in the FIS report. The FIS flow locations reported were matched to locations in the NRCS HEC-RAS model for comparison. The flow in the secondary channel around the cemetery was accounted for in the FIS by subtracting the flows downstream of the channel split (station 27,595) from flows upstream of the channel split (station 30,363) for a given AEP and assigning the difference to the diversion reach. 


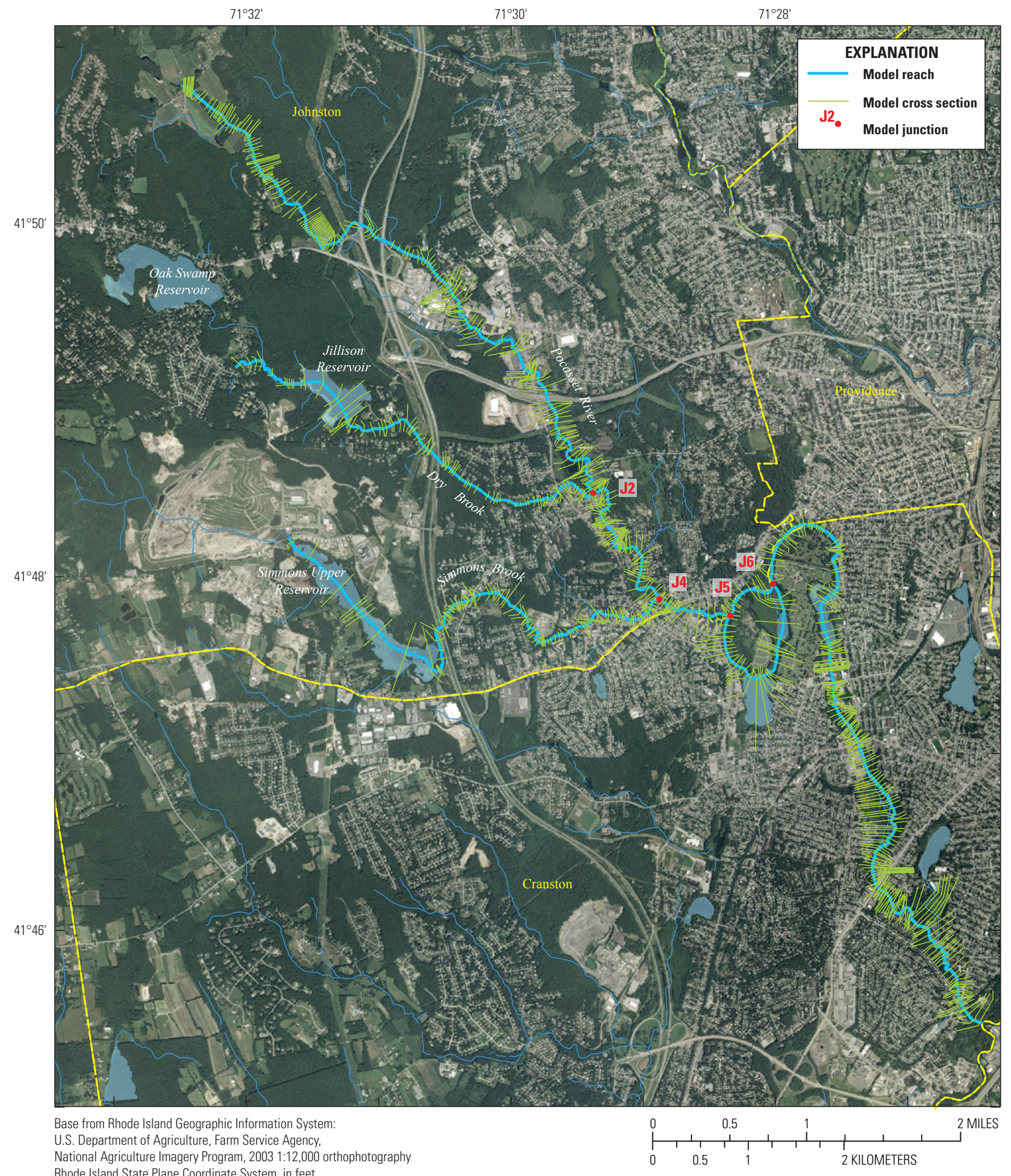

Figure 2-1. Hydraulic model reaches for the Pocasset River Basin, Rhode Island. 
Table 2-1. Hydraulic model reach segments for the Pocasset River Basin, Rhode Island.

\begin{tabular}{ccl}
\hline Reach name & $\begin{array}{c}\text { Length } \\
\text { (miles) }\end{array}$ & Description \\
\hline Pocasset River & 4.8 & Start of model to the confluence of Dry Brook \\
Johnston Upper & 1.2 & Confluence of Dry Brook to the confluence of Simmons Brook \\
Johnston Lower & .54 & Confluence of Simmons Brook to the river split junction near St. Ann's Cemetery \\
Cranston Upper & .51 & $\begin{array}{l}\text { Main channel flow to the north of the river split } \\
\text { Cemetery North }\end{array}$ \\
Cemetery South & 1.1 & $\begin{array}{l}\text { Secondary channel along the west side of St. Ann's Cemetery into Randall Pond then back north } \\
\text { through Dyer Pond where it rejoins the river }\end{array}$ \\
Cranston Lower & 4.8 & From the split junction to the confluence with the Pawtuxet River \\
Dry Brook & 3.0 & Downstream of Jillison Reservoir to confluence \\
Simmons Brook & 3.6 & Upstream of Upper Simmons Reservoir to confluence \\
\hline
\end{tabular}

The updated (2006) NRCS model also used TR-20 and divided the basin into 25 subcatchments to uniquely define the runoff curve number for different areas of the basin. The synthetic total precipitation was determined from extreme precipitation in New England (DeGaetano and Zarrow, undated) and distributed using a type-III rainfall distribution to generate an input time series for the TR-20 model. TR-20 generated discharge time series for unsteady-flow simulations and peak flows for steady-state simulations at different points in the basin for input into the NRCS HEC-RAS model. The existing NRCS model steady-state flow file "TR-20 Present and March 21-22-03; New CN" were used for model comparison.

The updated flow file in this study used regionalregression equations developed by Zarriello and others (2012) from drainage area in square miles $\left(\mathrm{mi}^{2}\right)$, stream density $\left(\mathrm{mi} / \mathrm{mi}^{2}\right)$, and percentage of the basin classified as storage in the National Hydrography Dataset (NHD). The amount of flow diverted to the Cemetery South reach (Pocas Riv Split also referred to as the cemetery diversion) was estimated by applying the same percentage of flow diverted to the Cemetery South reach in the NRCS model to the flow estimated by the regional regression. The flows through the Cemetery North reach (main channel) were then calculated by subtracting the flows from the Cemetery South reach from the flows upstream of the split (station 30,363) and rounded up to account for the additional drainage area. Flows specified in the updated model in this study are summarized in table $2-2$.

\section{Hydraulic Analysis}

The hydraulic model was unchanged from the model developed by the NRCS in 2006, with the exception of flow. The NRCS model updated cross-section geometry from $2-\mathrm{ft}$ contour digital elevations and from field surveys mostly at structures that affect the channel conveyance. The NRCS model is georeferenced to North American Datum of 1983 (NAD 83) horizontal datum and North American Vertical Datum of 1988 (NAVD 88).

Flow in the main stem of the Pocasset River can be affected by 10 bridges, 15 culverts, and 4 dams and in the cemetery diversion channel by 1 culvert. Flow in Dry Brook can be affected by one bridge, four culverts, and two dams. Flow in Simmons Brook can be affected by two bridges, five culverts, and two dams. The structural geometry in the model generally appears to match reconnaissance photographs taken in this study to the extent it could be assessed; however, this evaluation is far from inclusive of all structures. The model is well defined by 493 cross sections in the Pocasset River, 93 in Dry Brook, and 128 in Simmons Brook (fig. 2-1). The cemetery diversion is defined by 35 cross sections. Channel obstructions, ineffective flow areas, and levees are used in the model as needed.

Manning's roughness coefficient (n) values for the Pocasset River range from 0.025 to 0.100 in the channel and from 0.040 to 0.130 on the overbank areas. The $n$-values for Dry Brook ranged from 0.040 to 0.100 in the channel and from 0.040 to 0.100 on the overbank areas. The n-values for Simmons Brook ranged from 0.040 to 0.100 in the channel and from 0.035 to 0.100 on the overbank areas. More than three " $n$ " values often were used to define the roughness with higher values specified for the channel banks.

The NRCS model used normal depth at the boundary conditions at the confluence of the Dry and Simmons Brooks with the Pocasset River and at the confluence of the Pocasset River with the Pawtuxet River. These reaches can be affected by backwater near their confluences. No errors are reported in the model-run file, and the warnings appear to be acceptable. Further details about the hydraulic analysis can be found in Bachand and others (2007) and Schmidt and others (2007). 
Table 2-2. Annual exceedance probability flows used in the U.S. Geological Survey hydraulic model of the Pocasset River Basin.

[fts/s, cubic feet per second; $\mathrm{mi}^{2}$, square mile; river station rounded to nearest foot; --, not available]

\begin{tabular}{|c|c|c|c|c|c|c|c|}
\hline \multirow[t]{2}{*}{ Description } & \multicolumn{2}{|c|}{ River station } & \multirow{2}{*}{$\begin{array}{c}\text { Drainage } \\
\text { area }^{1} \\
\left(\mathrm{mi}^{2}\right)\end{array}$} & \multicolumn{4}{|c|}{$\begin{array}{c}\text { Discharge }\left(\mathrm{ft}^{3} / \mathrm{s}\right) \text { for specified percent } \\
\text { annual exceedance probability }\end{array}$} \\
\hline & From & To & & 10 & 2 & 1 & 0.2 \\
\hline Upstream of Interstate 295 & 61,943 & 50,455 & 2.52 & 160 & 270 & 320 & 460 \\
\hline Downstream of Interstate 295 & 50,379 & 47,034 & 3.39 & 200 & 350 & 420 & 590 \\
\hline Downstream of Dry Brook & 36,623 & 30,433 & 8.44 & 330 & 540 & 650 & 910 \\
\hline Downstream of Simmons Brook & 30,363 & 27,786 & 15.8 & 630 & 1,050 & 1,250 & 1,760 \\
\hline Main stem below cemetery diversion & 27,595 & 25,770 & -- & 550 & 840 & 940 & 1,220 \\
\hline Cemetery diversion (Pocas Riv Split) & 6,559 & 619 & -- & 80 & 210 & 310 & 550 \\
\hline Upstream of Reservoir Avenue & 15,793 & 1,563 & 2.40 & 40 & 60 & 80 & 100 \\
\hline Upstream of Atwood Avenue & 1,550 & 1,127 & 3.20 & 70 & 120 & 150 & 200 \\
\hline Between confluence with Pocasset River and Atwood Avenue & 870 & 132 & 3.31 & 80 & 130 & 160 & 210 \\
\hline \multicolumn{8}{|c|}{ Simmons Brook } \\
\hline $\begin{array}{l}\text { Downstream of Shun Pike and upstream of Simmons Upper } \\
\text { Reservoir }\end{array}$ & 18,921 & 11,928 & 4.30 & 180 & 300 & 360 & 500 \\
\hline Outlet of Simmons Lower Reservoir & 11,882 & 8,674 & 4.58 & 200 & 340 & 400 & 570 \\
\hline Downstream of Simmonsville Avenue & 8,616 & 3,046 & 4.92 & 220 & 380 & 450 & 640 \\
\hline Downstream of Mill Street & 3,012 & 156 & 5.92 & 290 & 490 & 580 & 830 \\
\hline
\end{tabular}

'The drainage area is the downstream point ("To" station) where the flow was determined; the "From" station and "Description" is the upstream point where the flow is first specified.

\section{References}

Bachand, J.A., Schmidt, Joel, Hardmeyer, Kent, Horter, Benjamin, and Carey, Constance, 2006, Pocasset River flood plain management study: Warwick, R.I., U.S. Department of Agriculture-Natural Resources Conservation Service, RI-TP-2006-1 [variously paged].

DeGaetano, Art, and Zarrow, Dan, [n.d.], Extreme precipitation in New York \& New England Technical Manual (ver. 1.12): Ithaca, N.Y., Cornell University, Northeast Regional Climate Center, 92 p. (available at http://precip.eas.cornell.edu/docs/xprecip_techdoc.pdf.)
Schmidt, Joel, Bachand, J.A., and Giaquinto, Clyde, 2007, Pocasset River flood plain management study: Warwick, R.I., U.S. Department of Agriculture-Natural Resources Conservation Service, RI-TP-2006-2, 37 p.

Zarriello, P.J., Ahearn, E.A., and Levin, S.B., 2012, Magnitude of flood flows for selected annual exceedance probabilities in Rhode Island, through 2010: U.S. Geological Survey Scientific Investigations Report 2012-5109, 93 p. (available at http://pubs.usgs.gov/sir/2012/5109.) 
THIS PAGE INTENTIONALLY LEFT BLANK 
Prepared by the Pembroke and Columbus Publishing Service Centers.

For more information concerning this report, contact:

Office Chief

U.S. Geological Survey

New England Water Science Center

Massachusetts-Rhode Island Office

10 Bearfoot Road

Northborough, MA 01532

dc_ma@usgs.gov

or visit our Web site at:

http://ma.water.usgs.gov 
